\author{
Universidade de São Paulo \\ Instituto de Física
}

\title{
Interação entre um peptídeo antimicrobiano e vesículas de fosfolipídeos
}

\author{
Nathaly Lopes Archilha
}

Orientador: Prof ${ }^{a}$. Dra. Rosangela Itri

Banca Examinadora

Prof $^{\mathrm{o}}$ Dra. Rosangela Itri (IFUSP)

Prof $^{\circ}$ Dr. Marcel Tabak (IQSC)

Prof ${ }^{\mathrm{a}}$ Dra. Iolanda Midea Cuccovia (IQUSP)

Dissertação de mestrado apresentada ao Instituto de Física para a obtenção do título de Mestre em Ciências 
FICHA CATALOGRÁFICA

Preparada pelo Serviço de Biblioteca e Informação do Instituto de Física da Universidade de São Paulo

Archilha, Nathaly Lopes

Interação entre um peptídeo antimicrobiano e vesículas de fosfolipídeos - São Paulo - 2009.

Dissertação (Mestrado) - Universidade de São Paulo. Instituto de Física. Departamento de Física Aplicada

Orientador: Prof. Dra. Rosangela Itri

Área de Concentração: Biofísical

Unitermos: 1. Física; 2. Biofísica; 3. Física Experimental.

USP/IF/SBI-021/2009 
"Eu não sei o que eu posso parecer ao mundo, mas no que concerne a mim eu pareço ter sido apenas um menino brincando às margens do oceano, $e$ me distraindo em ocasionalmente achar uma pedrinha mais lisa ou uma concha mais bonita que as comuns, enquanto o grande oceano da verdade permanece ainda a ser descoberto" 


\begin{abstract}
À minha família: minha mãe, minha vó, minha tia e meu namorado. Pelo apoio incondicional ao longo desses anos.
\end{abstract}




\section{Agradecimentos}

À Prof ${ }^{a}$ Dra. Rosangela Itri, pela orientação, confiança e amizade. Obrigada por entender minhas limitações, ressaltar meu pontos positivos e sempre me incentivar a continuar. E também por me permitir e possibilitar conhecer e trabalhar com pessoas incríveis. Obrigada pela paciência, pelos vários sorvetes e chocolates!

À Prof ${ }^{a}$ Dra. Karin do Amaral Riske, por me ajudar desde o início da iniciação científica e por sempre estar disposta a esclarecer minhas dúvidas! E, principalmente, pela amizade que construímos nesses anos.

Ao Dr. Carlos Marques e ao Dr. André Schroder, por ter permitido a utilização do Laboratório do Grupo $M^{3}$ : Membrane and Microforces, Strasbourg, França. Pelas discussões, propostas e grande ajuda. E também por terem me mostrado neve de verdade!

Á Prof ${ }^{o}$ Iolanda Midea Cuccovia, por ter permitido o uso do Laboratório de Sistemas Biomiméticos do IQUSP para a realização das medidas de fluorescência do triptofano e de cinética de vazamento de CF.

À Prof ${ }^{a}$ Dra. Georgina Tonarelli, por ter gentilmente cedido o peptídeo para a realização deste trabalho.

À Prof ${ }^{a}$ Dra. Leila Beltramini, pelas várias discussões e por permitir o uso do Laboratório de Biofísica do IFSC, para realizar as medidas de Dicroísmo Circular.

À Prof ${ }^{a}$ Dra. Patrícia Targon Campana, por inúmeras discussões e esclarecimentos de dúvidas.

À Prof ${ }^{a}$ Dra. Shirley Schreier e ao Prof ${ }^{o}$ Dr. Carlos Alvarez pelas poucas, porém valiosas, discussões realizadas nesses últimos meses. Em especial à Prof ${ }^{a}$ Shirley por transparecer sua grande vontade em ensinar as pessoas.

À Prof ${ }^{a}$ Maria Tereza Lamy-Freund Thereza, por permitir a utilização do Laboratório de Biofísica do IFUSP, onde preparei parte das minhas amostras.

Ao Prof ${ }^{\circ}$ Dr. Oscar Éboli, por me ensinar a não me importar com pessoas que não valem a pena.

À Dra. Katia Regina Perez Daghastanli, por ter proposto e colaborado com este trabalho. Por sua incrível disposição em discutir qualquer coisa, em qualquer lugar. Pelo seu grande bom humor e também pela grande amizade criada nesses anos. 
Ao Dr. Evandro Luiz Duarte, por me ajudar com as dúvidas mais básicas, desde o início da minha primeira iniciação científica. Obrigado pela grande ajuda em absolutamente tudo que fiz em Strasbourg. Desde achar um restaurante gostoso, até a utilizar os microscópios.

Ao Sr. José Luiz de Souza Lopes, pela grande ajuda na realização das medidas de Dicroísmo Circular. E a todos os alunos da Biofísica de São Carlos, em especial, a Bel, por me abrigar em São Carlos, a Thaty, Joci, Susso, Anderson, Julio(s) e Sheila por me divertirem muito no pouco tempo que fiquei em São Carlos.

Aos meus amigos do Laboratório de Cristalografia, entre eles: Tati, Elisa, Dani, Thais, Serena, Lele e Nasser, pelas muitas risadas e incentivo. Aos técnicos Antonio Carlos e Sérgio, pela ajuda com computadores e fabricação de peças.

Aos meus amigos do IFUSP, Felis, Ivanildo, LM, Renata, Zwinglio, Lelas, Kenia, Melina, Jair, Pri, Liria, Amanda, os Jahnke, Felipe, Raphael... e todos que fizeram do IFUSP um lugar muito mais feliz. Obrigada pelas muitas conversas, pelos muitos cafés e pizzas, pelas discussões e risadas. Obrigada por suportarem minhas crises e me ajudarem a superá-las.

À minha mãe Miriam e vó Ignês, pelo apoio por todos esses anos. Pela força que vocês possuem e por sempre me ajudarem em tudo que fiz na vida. À minha tia Mirena, pela ajuda e torcida, por praticamente ter me forçado a prestar o vestibular... que eu passei e entrei no IFUSP. Obrigada por tudo que vocês fizeram por mim!!

Ao meu namorado Thiago, por sempre me apoiar, pela confiança, carinho e acima de tudo pelo seu amor. Obrigada por ser minha paz.

Às minhas amigas, Karol e Paula, pela amizade de muitos anos. Pelas muitas conversas, várias viagens, risada e planos mirabolantes. Obrigada por sempre estarem por perto (desde pequenininhas) quando precisei de vocês.

Ás secretárias da FAP, Inês e Lia, pela disposição em ajudar, sempre.

Aos funcionários da Comissão de Pós Graduação Fran e Éber. Obrigada pela atenção e pelas instruções valiosas.

À FAPESP, pelo financiamento dessa pesquisa.

Ao CNRS, pela bolsa concedida para o estágio realizado em Strasbourg.

Ao IFUSP, pela infra- estrutura oferecida.

Ao Laboratório de Cristalografia, por oferecer as condições necessárias para execução deste trabalho. 


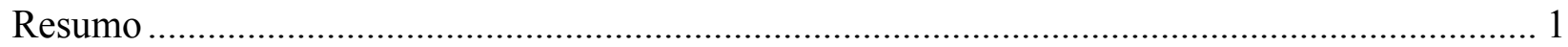

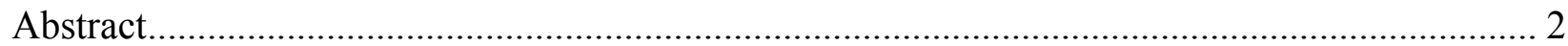

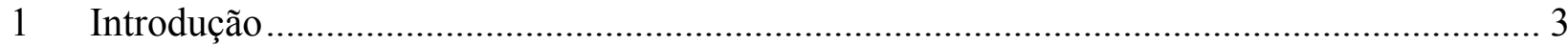

1.1 Peptídeos antimicrobianos: o que são e por que estudá-los?.......................................... 3

1.1.1 Modos de Ação de Peptídeos Bactericidas............................................................... 6

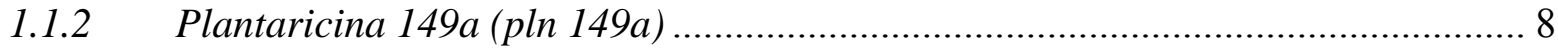

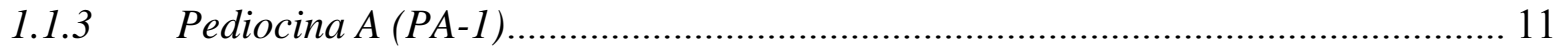

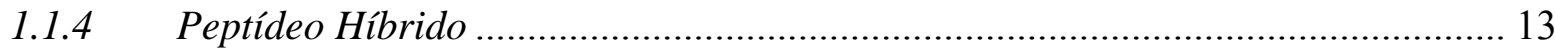

1.2 Membranas modelo: quais tipos são relevantes para o estudo? ……………………... 17

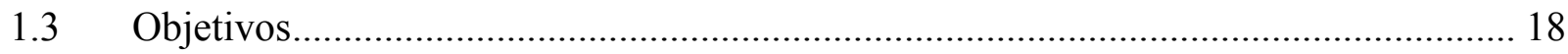

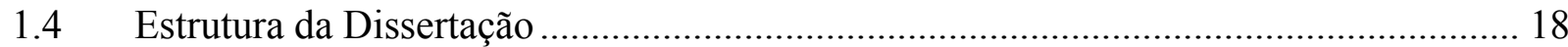

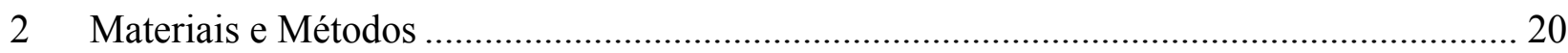

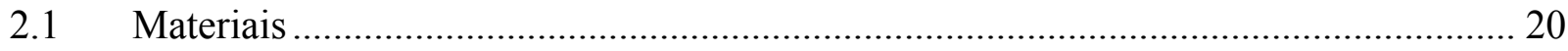

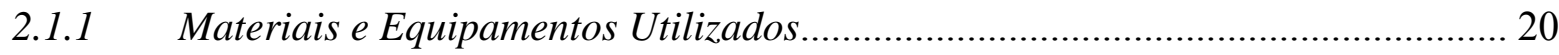

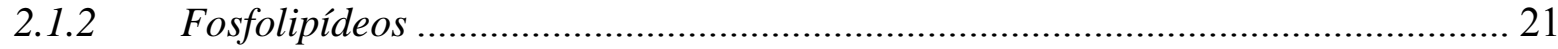

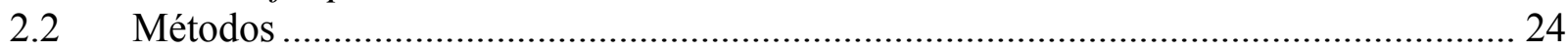

2.2.1 Preparação das Vesículas Unilamelares Grandes (LUVs) ................................... 24

2.2.2 Preparação das Vesículas Unilamelares Gigantes (GUVs)................................. 26

2.2.3 Microscopia Óptica ................................................................................... 28

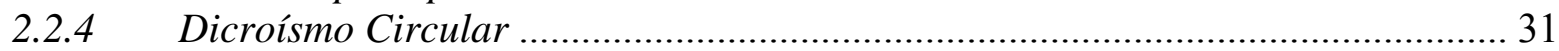

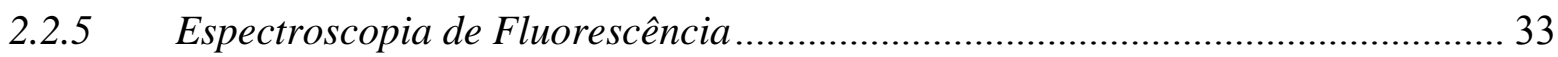

3 Resultados dos Métodos Espectroscópicos e Discussões........................................................ 39

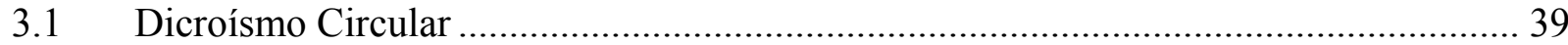

3.2 Sondagem da fluorescência do triptofano ……………............................................. 41

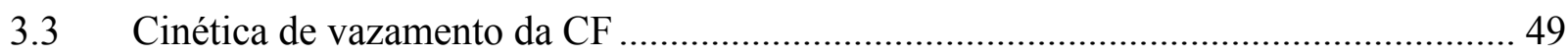

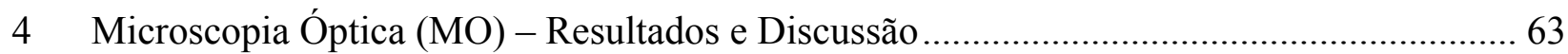

4.1 Interação de Membranas Modelo (GUVs) com o Peptídeo Híbrido .................................. 63

4.2 Interação de Membranas Modelo com Moléculas Anfifílicas.......................................... 69

4.2.1 Estudos Realizados com Triton $X-100$.............................................................. 72

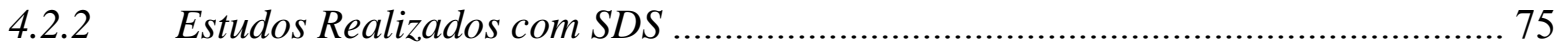

4.3 Efeito do peptídeo híbrido em GUVs em comparação com o dos detergentes .............. 80

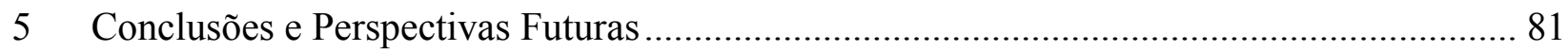

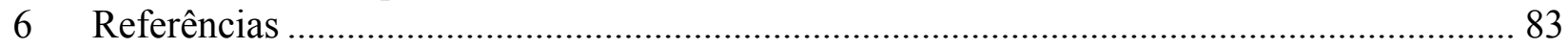




\section{Resumo}

Neste trabalho, estudamos a interação de um peptídeo antimicrobiano com membranas modelo, por meio de dicroísmo circular (CD), fluorescência e microscopia óptica. Tal peptídeo, chamado de híbrido, foi sintetizado como uma mistura das regiões mais ativas de dois outros peptídeos antimicrobianos, chamados de pediocina A e plantaricina 149. Esse peptídeo híbrido possui carga de +8 , em $\mathrm{pH}$ fisiológico, e as membranas estudadas foram compostas por uma mistura de fosfolipídeos zwiteriônicos (cabeça polar de fosfatidilcolina, PC) e aniônicos (cabeça polar de fosfatidilglicerol, PG), em diferentes razões molares.

Os resultados de CD evidenciaram que este peptídeo se apresenta de forma desordenada em solução aquosa, porém adota uma conformação helicoidal na presença de grandes vesículas unilamelares carregadas negativamente (LUVs). A quantidade de componente helicoidal é dependente da quantidade de lipídeo negativo presente na bicamada lipídica.

A fluorescência do triptofano revelou um deslocamento para o azul muito significativo, chegando a $20 \mathrm{~nm}$ para membranas compostas por $100 \mathrm{~mol} \%$ de PG. Os dois resultados (CD e fluorescência) indicam que a região dos aminoácidos que contém o triptofano deve estar interagindo muito fortemente com a região hidrofóbica da membrana, numa conformação tipohelicoidal.

Experimentos de vazamento de carboxifluoresceína encapsulada em LUVs, por espectroscopia de fluorescência, demonstraram a ação lítica do peptídeo induzindo a formação de poros nas membranas, independentemente da composição das LUVs. Entretanto, a razão molar peptídeo:lipídeo necessária para induzir vazamento da sonda foi menor para membranas lipídicas compostas por bicamadas contendo altas quantidades de PG. Tal fato coloca em evidência o papel fundamental da interação eletrostática entre os peptídeos carregados positivamente com as membranas carregadas negativamente para o processo de ligação e mecanismo de ação deste peptídeo.

Para estudar mais detalhadamente o mecanismo de ação, realizamos experimentos de microscopia óptica em vesículas unilamelares gigantes. Concluímos que o peptídeo provoca total desestabilização das vesículas unilamelares gigantes, com formação de poros, seguidos de ruptura da bicamada lipídica e sua transformação em pequenos e mal definidos complexos de peptídeos e fosfolipídeos. 


\begin{abstract}
In this work, we investigated the interaction between an antibacterial peptide with model membranes, by means of circular dichroism (CD), fluorescence and optical microscopy. Such a peptide was synthesized from the most active regions of two others antimicrobial peptides, namely pediocin A and plantaricin 149. The hybrid peptide has a net charge of $\sim+8$, at physiological $\mathrm{pH}$, and the studied model membranes were composed of a mixture of zwitterionic phospholipids (phosphatidylcholine polar head) and anionic phospholipids (phosphatidylglycerol polar head), at differente molar ratio.

The CD results evidenced that the peptide was essentially structureless in aqueous solution, but acquired an $\alpha$ - helical conformation in the presence of charged large unillamellar vesicles LUVs. The $\alpha$ - helical content is dependent on the negative charge amount on membrane surface.

The tryptophan fluorescence revealed a significant blue - shift of the maximium emission wavelength, up to $20 \mathrm{~nm}$ for the membranes composed of $100 \mathrm{~mol} \%$ of PG in respect to the peptide fluorescence in the aqueous solution. This indicates that part of the aminoacid residues, that contains the tryptophan, must be buried into the hydrophobic medium of the lipid membrane.

Leakage experiments using fluorescence spectroscopy of carboxyfluorescein encapsulated in LUVs demonstrated the lytic action of the peptide, inducing the pore formation in the membrane, regardless of lipid membrane composition. However, it should be stressed that the peptide:lipid molar ratio necessary to induce probe leakage was smaller for lipid membranes made up of large PG amounts. Such evidence points out the key role of the electrostatic interaction between a positively charged peptide and the negatively charged membrane, mediated by hydrophobic contribution.

To gain further insight into the lytic mechanism of the peptide, we performed single vesicle experiments using giant unilamellar vesicles under optical microscopy observations. We conclude that the peptide provokes a total membrane desestabilization, with pore formation, followed by a membrane disruption and its transformation into smaller and not well defined complexes of phospholipids and peptides.
\end{abstract}




\section{Introdução}

\subsection{Peptídeos antimicrobianos: o que são e por que estudá-los?}

Peptídeos, assim como proteínas, são constituídos por uma seqüência de $\alpha$-aminoácidos. É comum na literatura definir-se peptídeos ou polipeptídeos como moléculas formadas por até 100 aminoácidos. Acima dessa quantidade, as moléculas são chamadas de proteínas [1,2].

Os aminoácidos são moléculas orgânicas, compostas por uma estrutura comum (átomos de hidrogênio, nitrogênio, carbono e oxigênio) e um radical, representado pela letra $\mathrm{R}$ na figura 1 , que diferencia os 20 distintos aminoácidos. Estes são apresentados na figura 2. Nessa figura também estão apresentados os códigos de uma e três letras para o nome dos aminoácidos. Por exemplo, o primeiro aminoácido é a Alanina, que, pelo código de três letras, é Ala e pelo de uma letra é $A$.

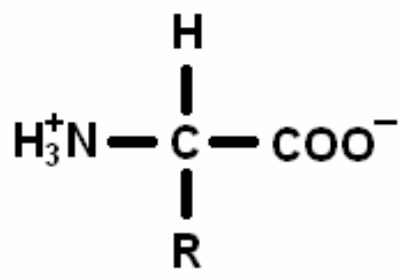

Figura 1 - Estrutura comum entre os aminoácidos.

Os aminoácidos são classificados de diversas formas, sendo que uma delas é através de sua afinidade por água, pois os radicais (R) podem ser polares ou apolares. Uma forma de também caracterizá-los é através da carga que eles possuem, de acordo com o $\mathrm{pH}$ do meio, podendo ser neutros, positivos ou negativos. A tabela 1 apresenta valores de hidrofilicidade [3], que classifica cada um dos aminoácidos entre hidrofílicos e hidrofóbicos e sua respectiva carga em $\mathrm{pH} 7,0$. 


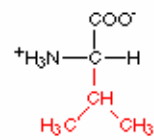

Valina (ValN)

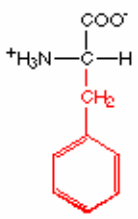

Fenilalanina (Fen, F)<smiles>[NH3+][C@H](CS)C(=O)[O-]</smiles>

Cisteina (Cisic)<smiles>[NH3+]C(CCC(=O)[O-])C(=O)[O-]</smiles>

Ácido glutâmico (GluiE)

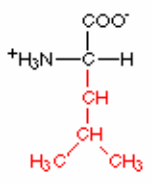

Leucina (Leun)<smiles>CC(N)C(=O)[O-]</smiles>

Alanina (Ala/A)

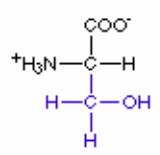

Serina (Seris)

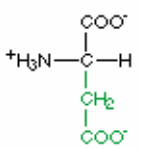

Ácido aspártico (AspN)
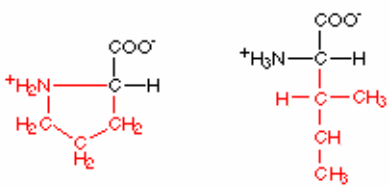

Prolina

Triptofano (TrpM)
Isoleucina

(llen)

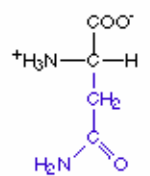

Asparagina

(AsnN)

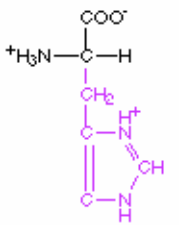

Histidina (His.H)

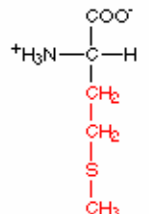

Metionina (MetM)

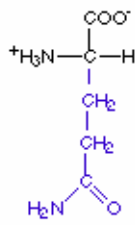

Glutamina (GIn/Q)

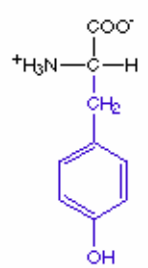

Tirosina (TirM)

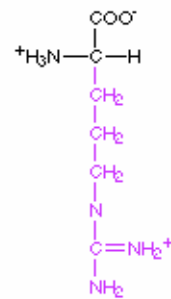

Arginina (ArgR)

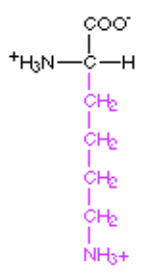

Lisina (Lis/)

Figura 2 - Os vinte diferentes aminoácidos que compõem a estrutura primária de peptídeos e proteínas e o código de uma e três letras, comumente utilizado no meio científico. Figura extraída e modificada de [4]. 


\begin{tabular}{|c|c|c|c|c|c|}
\hline Aminoácido & $\begin{array}{c}\text { Valor da } \\
\text { hidrofilicidade }\end{array}$ & $\begin{array}{c}\text { Carga em } \\
\text { pH 7,0 }\end{array}$ & Aminoácido & $\begin{array}{c}\text { Valor da } \\
\text { hidrofilicidade }\end{array}$ & $\begin{array}{c}\text { Carga em } \\
\text { pH 7,0 }\end{array}$ \\
\hline Arginina & 3,0 & Positiva & Alanina & $-0,5$ & Neutra \\
\hline Ácido Aspártico & 3,0 & Negativa & Histidina & $-0,5$ & Positiva \\
\hline Ácido Glutâmico & 3,0 & Negativo & Cisteína & $-1,0$ & Neutra \\
\hline Lisina & 3,0 & Positiva & Metionina & $-1,3$ & Neutra \\
\hline Serina & 0,3 & Neutra & Valina & $-1,5$ & Neutra \\
\hline Asparagina & 0,2 & Neutra & Isoleucina & $-1,8$ & Neutra \\
\hline Glutamina & 0,2 & Neutra & Leucina & $-1,8$ & Neutra \\
\hline Glicina & 0 & Neutra & Tirosina & $-2,3$ & Neutra \\
\hline Prolina & 0 & Neutra & Fenilalanina & $-2,5$ & Neutra \\
\hline Treonina & $-0,4$ & Neutra & Triptofano & $-3,4$ & Neutra \\
\hline
\end{tabular}

Tabela 1 - Escala de hidrofilicidade dos 20 aminoácidos, relacionando-os do mais hidrofílico (arginina), até o mais hidrofóbico (triptofano). Tabela extraída de [3].

Neste trabalho focaremos nossa atenção nos peptídeos antimicrobianos. Estes são pequenos (podem conter entre 12 e 100 aminoácidos), geralmente catiônicos (carga total entre +2 e +9 ), possuem mais de $50 \%$ de resíduos (aminoácidos) hidrofóbicos, podem ser produzidos e isolados a partir de vários organismos (insetos, plantas, animais e até mesmo de microorganismos unicelulares), ou ainda podem ser sintetizados em laboratórios [5].

Mas, por que estudá-los? Atualmente, peptídeos catiônicos estão cada vez mais em evidência, pois são reconhecidos como potenciais agentes antimicrobianos. Eles são produzidos pela maioria das espécies de seres vivos e possuem grande importância no processo de defesa do organismo [5]. A relevância atinge diversas áreas, como a indústria farmacêutica e alimentícia. Atualmente, a indústria farmacêutica possui urgência na descoberta de novas classes de antibióticos, pois apenas três foram desenvolvidas nos últimos 40 anos. Além do interesse no poder que alguns peptídeos possuem de matar bactérias que são resistentes a várias drogas comerciais, existe ainda a possibilidade de utilizá-los em combinação com os antibióticos comerciais já conhecidos, com o objetivo de se obter um efeito sinergético [6]. O interesse da indústria alimentícia se baseia no fato de que os peptídeos podem inibir o crescimento de algumas bactérias, permitindo, assim, a fabricação de produtos mais saudáveis e naturais [7]. Um dos peptídeos mais estudados até hoje é um antibiótico, chamado de nisina [8]. Ele é produzido por 
Lactococcus lactis e é utilizado pela indústria alimentícia há mais de 50 anos como conservante alimentar. A nisina age em uma grande variedade de bactérias gram-positivas, sendo utilizado em uma concentração muito baixa, da ordem de $10^{-9}$ molar [5].

Embora existam vários bons motivos que justificam o interesse em utilizar os peptídeos antimicrobianos comercialmente, isto não ocorre. Hoje são conhecidos mais de 600 peptídeos que, além de matar microorganismos patogênicos, possuem um papel importante na defesa do organismo. Porém, ainda existem vários obstáculos no uso desses peptídeos e o principal deles é o alto custo de sua síntese em relação ao custo de um antibiótico já comercial. O preço, por grama, de um antibiótico convencional, como os da classe dos aminoglicosídeos (utilizado para o tratamento de cistite e pneumonias, por exemplo), é de $\$ 0,80$, enquanto que para um peptídeo antimicrobiano pode chegar a $\$ 400,00$. Outro ponto importante é que vários peptídeos exibem uma grande atividade in vitro, mas não as exibem sob condições fisiológicas. A possível causa é a presença de sal nesse meio [9]. Um outro grande obstáculo é a determinação da toxicidade desses peptídeos, pois poucos estudos foram realizados nessa área, uma vez que a grande maioria dos trabalhos focam na interação entre peptídeos e membranas, com o objetivo de determinar o mecanismo de ação dos peptídeos. Ou seja, focam no modo como eles atuam nas bactérias, vírus e fungos [6], sendo que isto deve ocorrer, ou se iniciar, a partir da interação do peptídeo com a membrana celular.

Os peptídeos antimicrobianos podem ser divididos entre antivirais, antibactericidas, antifúngicos e antiparasitas. Existem, na literatura, diferentes modos de ação propostos para cada um desses grupos. Como o peptídeo estudado nesse trabalho é um bactericida (veja seção 1.1.4), o foco será dado apenas ao mecanismo de ação desse tipo de peptídeo. Na seção 1.1.1 a seguir, apresentaremos um breve resumo sobre os possíveis modos de ação de peptídeos bactericidas.

\subsubsection{Modos de Ação de Peptídeos Bactericidas}

Existem diversos modos de ação de mecanismos propostos para peptídeos bactericidas na literatura, que diferem entre si. Porém, a ação final se resume em três: formação de poros transientes na bicamada, solubilização em agregados tipo micela e translocação do peptídeo através da membrana [5].

Acredita-se que o primeiro passo da interação entre esses peptídeos e as membranas seja a atração eletrostática entre as cargas positivas dos peptídeos e as cargas negativas da superfície 
das membranas de bactérias. O segundo passo é dado pelo caráter anfipático do peptídeo. A porção hidrofóbica terá preferência por interagir com a parte apolar dos lipídeos, enquanto que a porção hidrofílica irá interagir com a cabeça polar ou ficará exposta à água, em uma possível formação de poro [5]. A figura 3 apresenta quatro possíveis modo de ação de peptídeos bactericidas, propostas na literatura. Nessa figura a bicamada lipídica está representada em amarelo, os peptídeos são os cilindros, onde as regiões hidrofóbicas estão em azul e em vermelho estão as regiões hidrofílicas. A proposta A é chamada de modelo agregado. Inicialmente os peptídeos se orientam e se ligam na membrana lipídica; em seguida eles se inserem na bicamada lipídica, formando canais, que não obedecem nenhum padrão de orientação e tamanho, e/ou eles fazem uma translocação pela membrana, passando da monocamada externa para a interna. Esse é um mecanismo proposto para alguns peptídeos que agem no interior de membranas celulares (impedindo, por exemplo, a síntese de DNA e RNA). A proposta B é chamada de poro toroidal. Nesse modo de ação os peptídeos se inserem na bicamada com uma orientação perpendicular aos lipídeos, para que ocorra a formação de um poro. Nesse mecanismo é necessário que a bicamada lipídica, ao redor dos peptídeos, adote uma curvatura positiva, e que a parte apolar do peptídeo, juntamente com as cabeças polares dos fosfolipídeos, formem uma parede mista. A proposta $\mathrm{C}$ é chamada de barril, onde cada peptídeo se comporta como uma ripa de um barril. Os peptídeos se orientam e ficam na forma de um barril, se inserindo na bicamada lipídica, formando um poro de tamanho bem definido, expondo as regiões hidrofóbicas do peptídeo às cadeias hidrocarbônicas dos lipídeos e as regiões hidrofílicas ao canal do poro. Já a proposta D é chamada de carpete. Acredita-se que, nesse mecanismo de ação, é necessário o acúmulo de uma certa quantidade de peptídeos na superfície da bicamada lipídica e, ao atingi-la, ocorre um tipo de ação detergente, causando a solubilização de fragmentos da bicamada (processo de micelização). 
(A)

(B)

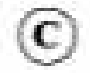

(D)
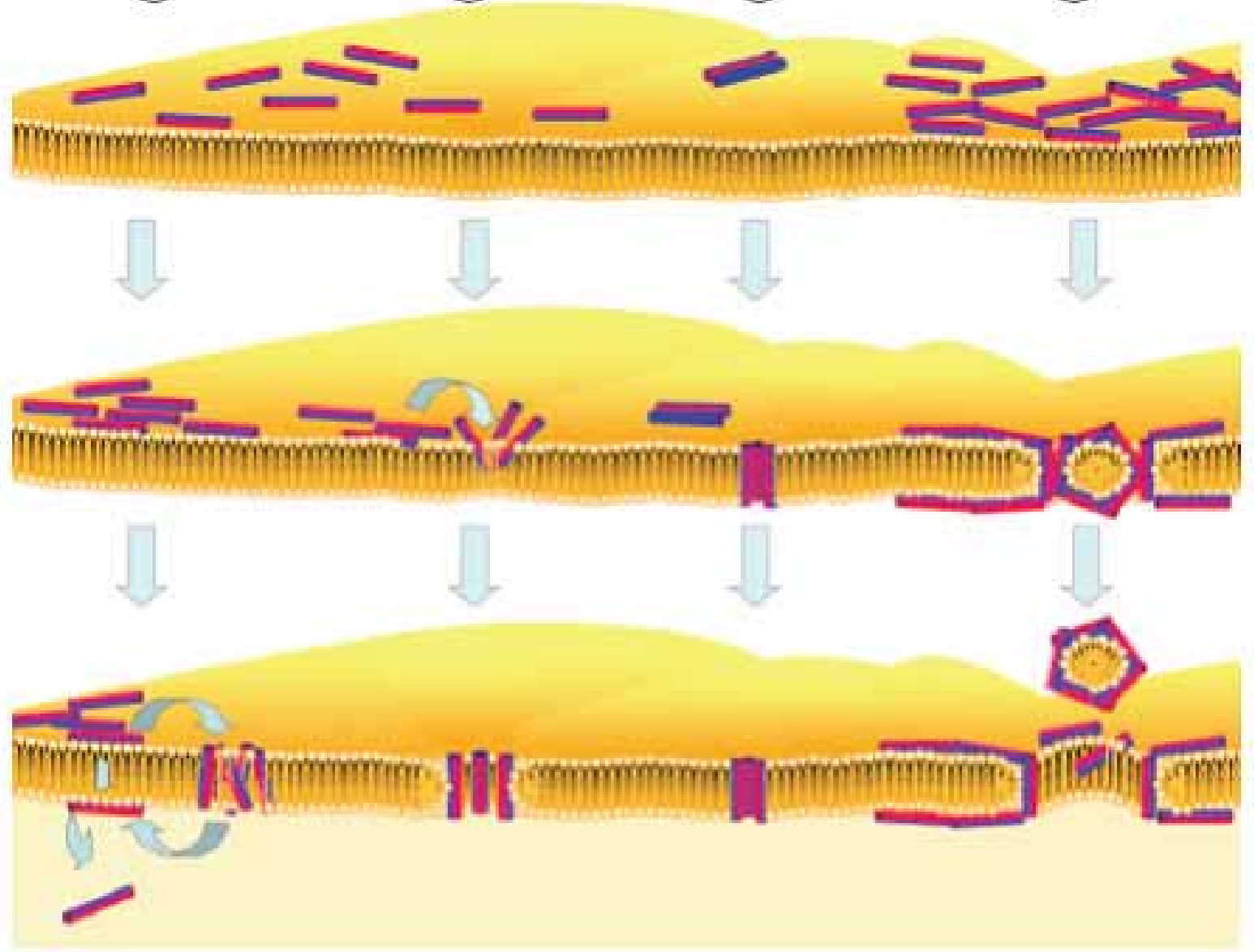

Figura 3 - Alguns dos possíveis mecanismos de ação de peptídeos bactericidas. Em amarelo está representada a bicamada lipídica, os peptídeos são os cilindros, formados de uma parte hidrofóbica (azul) e uma parte hidrofílica (vermelha). O mecanismo A é chamado de modo agregado, o B é o de poro toroidal, o C é o modelo de barril e o D é o carpete. Figura modificada de [5].

O peptídeo utilizado para esse estudo, que chamaremos apenas de peptídeo híbrido, será apresentado na seção 1.1.4. Esse peptídeo foi desenhado a partir das duas regiões mais ativas de dois outros peptídeos antimicrobianos: a plantaricina 149a e a pediocina A. Esses dois peptídeos serão apresentados nos itens a seguir.

\subsubsection{Plantaricina 149a (pln 149a)}

A plantaricina 149a é um peptídeo sintético análogo da plantaricina 149 (pln 149). Esse peptídeo é produzido pelo Lactobacillus plantarum NRIC149, isolado do abacaxi [10]. Ele possui 
22 aminoácidos, cuja seqüência é dada por YSLQMGATAIKQVKKLFKKKGG-a e seu peso molecular, estimado a partir dessa seqüência, é de $2424 \mathrm{~g} / \mathrm{mol}$.

A pln 149a sintética é ativa em duas espécies de bactérias: Listeria monocytogenes e Staphylococcus aureus, dois patógenos agressivos ao homem. Vale a pena ressaltar que a $L$. monocytogenes é resistente à nisina [8]. A concentração mínima de inibição (MIC) foi determinada através de diluição seriada em microplacas e foi considerada como sendo a concentração necessária para reduzir o crescimento das bactérias em 50\%. Para a Listeria monocytogenes a MIC determinada foi de $264 \mu \mathrm{M}$ e para o Staphylococcus aureus foi de 528 $\mu \mathrm{M}$. Esses valores são considerados muito altos e uma possível explicação é que o peptídeo tenha interagido fortemente com algum componente do meio de cultura das cepas [7].

Foram também utilizados eritrócitos humanos para testar a atividade hemolítica. Essas células foram incubadas com diversas concentrações do peptídeo, entre $10-165 \mu \mathrm{M}$. Os resultados mostraram que a pln 149a apresenta baixa atividade hemolítica, pois independentemente da concentração de peptídeo utilizada, a lise foi de apenas $16 \%$, após 1 hora de incubação.

Além disso, determinou-se que um dos modos de ação desse peptídeo é tipo bactericida, pois a quantidade de células viáveis por mililitro de S. aureus e de L. monocytogenes, após 6 horas de incubação com $75 \mu \mathrm{M}$ de peptídeo, é inferior a $10^{2}$, enquanto que o controle possui cerca de $10^{8}$ células viáveis por mililitro [7].

Determinou-se também um modelo molecular otimizado para a seqüência completa da plantaricina 149a [7]. Existem, basicamente, duas diferentes regiões nesse peptídeo: a região entre o $7^{\circ}$ e o $20^{\circ}$ aminoácido, que se apresenta na forma de $\alpha$-hélice anfipática, onde todos as lisinas (resíduos polares - tabela 1) estão ao longo de apenas um lado da hélice e os resíduos apolares (isoleucina, valina, leucina e fenilalanina - tabela 1) estão do outro lado da hélice. O restante dos peptídeos se apresentam na forma desordenada. A figura 4 apresenta a estrutura desse peptídeo, para uma melhor visualização do seu modelo molecular. 

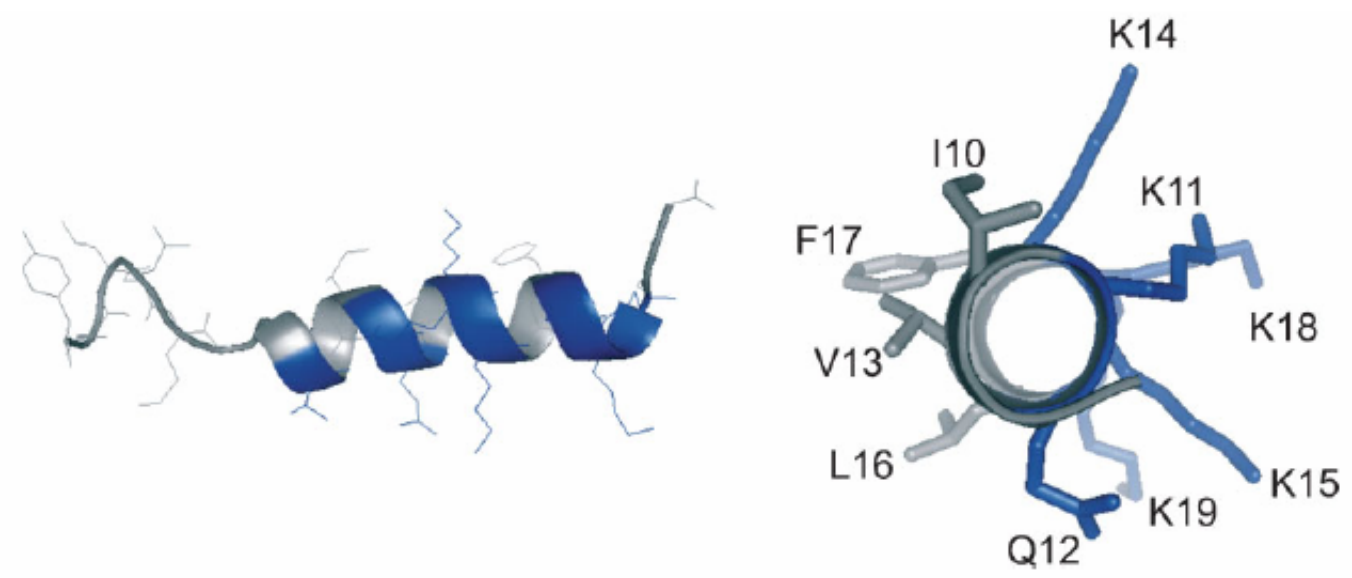

Figura 4 - Modelo molecular da plantaricina 149a. Do lado esquerdo está apresentada a estrutura secundária da pln 149a. Essa representação evidencia as duas diferentes regiões: a primeira em $\alpha$ hélice e a outra desordenada. Do lado direito temos apenas a região que forma $\alpha$-hélice, ficando clara a divisão de resíduos polares (lisinas, $K$ ) e dos apolares (isoleucinas, valinas, leucinas e fenilalaninas).

Figura extraída de [7].

Existem, ainda, sítios da internet que, com base em dados da literatura, fazem uma série de estimativas a partir da seqüência de aminoácidos do peptídeo. Entre eles está o sítio da Innovagen (http://www.innovagen.se) [11]. É possível obter uma série de informações sobre o peptídeo, através de sua seqüência de aminoácidos. São elas:

o O seu peso molecular;

o A carga total do peptídeo em função do $\mathrm{pH}$ da solução onde ele se encontra;

o O seu ponto isoelétrico, que é o valor de $\mathrm{pH}$ onde o peptídeo apresenta um balanço de carga nulo;

- A hidrofilicidade média, que é a soma dos valores de hidrofilicidade de cada uma dos resíduos (tabela 1), dividido pela quantidade total de resíduos e

o A relação entre a quantidade de resíduos hidrofílicos e a quantidade total de resíduos.

A figura 5, gerada pelo sítio acima citado, apresenta todas essas informações a partir da seqüência de aminoácidos da pln 149a. Essa figura apresenta um gráfico teórico da carga total do peptídeo em função do $\mathrm{pH}$ da solução. Esse peptídeo possui carga de $+7 \mathrm{em} \mathrm{pH} \mathrm{7,} \mathrm{que} \mathrm{é} \mathrm{muito}$ próximo do $\mathrm{pH}$ escolhido para o trabalho, de 7,4 (pH fisiológico). Essa curva teórica ainda mostra que o ponto isoelétrico é 11,2. Outra informação que essa figura nos fornece é a distribuição dos resíduos hidrofílicos e hidrofóbicos da cadeia peptídica. 


\begin{tabular}{l|l|l|}
$\begin{array}{l}\text { Peptide } \\
\text { N-terminus } \quad \text { Sequence (in either 1- or 3-letter-code) }\end{array}$ & \multicolumn{1}{c|}{ Request quotation! } \\
\hline (NH2-) $\vee$ YSLQMGATAIKQVKKLFKKKGG & C-terminus \\
\hline
\end{tabular}

Please denote modified amino acids by enclosing them in parentheses; e.g. (pS) or (pSer) for a phosphorylated Serine.

Interpreted sequence

1-letter code: YSLQMGATAIKQVKKLFKKKGG

3-letter code: Tyr-Ser-Leu-Gln-Met-Gly-Ala-Thr-Ala-lle-Lys-Gln-Val-Lys-Lys-Leu-Phe-Lys-Lys-Lys-Gly-Gly

\section{Number of residues: 22 Molecular weight, MW: \\ 2424}

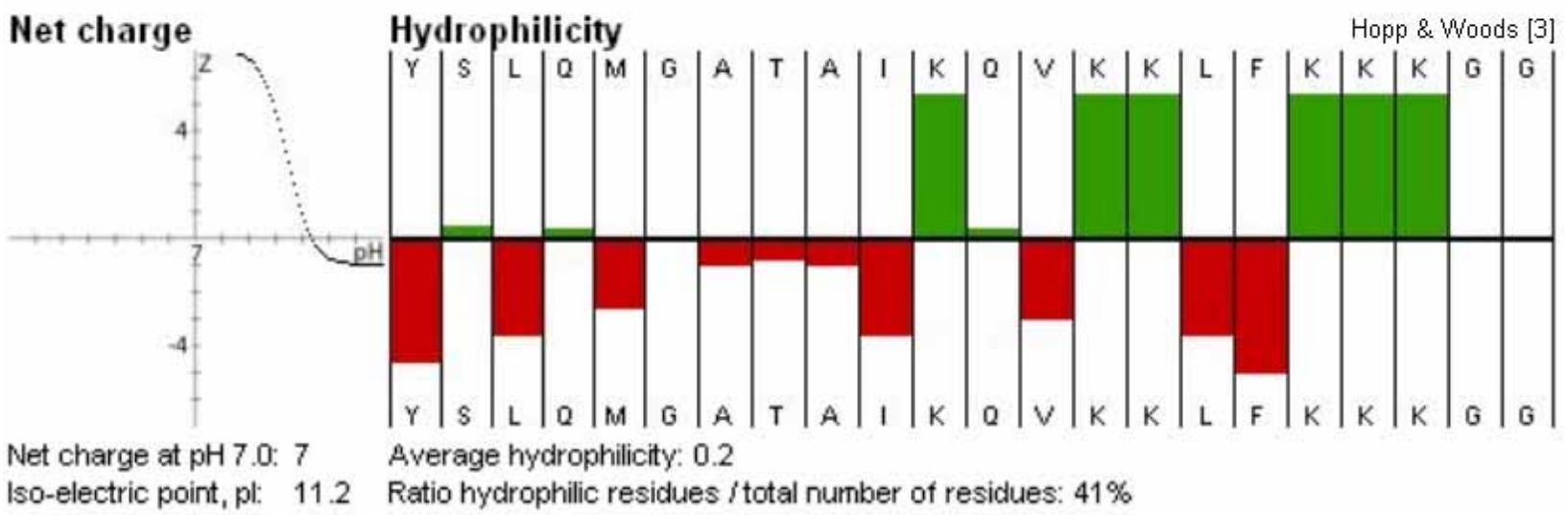

Figura 5 - Quadro com informações sobre a plantaricina 149a. Esse quadro foi gerado por [11] a partir da seqüência de aminoácidos da cadeia peptídica.

\subsubsection{Pediocina A (PA-1)}

A pediocina A é um peptídeo produzido por Pediococcus acidilactici. Sua seqüência de aminoácidos é KYYGNGVTCGKHSCSVDWGKATTCIINNGAMAWATGGHQGNHKC, com 44 resíduos. Seu peso molecular, estimado a partir dessa seqüência, é de 4628,2 g/mol.

Esse peptídeo possui uma grande atividade em bactérias gram-positivas, se destacando na ação contra a Listeria monocytogenes. Ela já é utilizada comercialmente na indústria alimentícia, pois é responsável por aumentar o tempo de conservação de alguns alimentos, inibindo o crescimento dessa bactéria, em particular em carnes prontas para consumo [12]. A concentração mínima de inibição para cepas de Listeria monocytogenes é de, aproximadamente, $25 \mathrm{nM}$ e ela não apresenta atividade hemolítica [13]. Portanto, a Pediocina mostra-se muito mais potente contra L. monocytogenes que a Plantaricina 149a.

Acredita-se que a pediocina A age nas membranas de bactérias através de algumas etapas. A primeira etapa é a ligação do peptídeo na membrana, seguida de sua inserção na bicamada 
lipídica e, por fim, a formação de poro [14]. Como o primeiro passo desse processo de rompimento da membrana é considerado fundamental para todo o mecanismo de ação, esse passo foi estudado mais especificamente. Um modelo de estrutura foi proposto para a região $\mathrm{N}$ terminal da pediocina A (resíduos 1 a 18) [14]. Acredita-se que essa porção assume uma conformação de folha $\beta$, contendo duas lisinas $(\mathrm{K})$, aminoácidos polares carregados positivamente (tabela 1), que, provavelmente, são importantes para a ligação inicial do peptídeo à membrana. Ainda nessa região se encontra a seqüência de aminoácidos YGNGV que, hipoteticamente, é a região do peptídeo que faz o reconhecimento da membrana da Listeria monocytogenes [14]. Experimentos de fluorescência do triptofano (aminoácido fluorescente) com o fragmento pediocina N15 (que possui os 14 primeiros resíduos da PA-1, a não ser pela troca de uma tirosina (Y) por um triptofano (W) e que possui a seguinte seqüência: WKYGNGVTCGKHSCS) mostraram que essa região realmente se liga à superfície da membrana, pois o máximo de emissão do espectro de fluorescência do triptofano sofre um aumento de intensidade e um deslocamento para o azul (blue shift) quando uma dispersão de membranas lipídicas aniônicas é adicionada à solução contendo o peptídeo. Resultado muito semelhante foi encontrado quando esse mesmo experimento foi realizado com a pediocina A. Isso mostra que a pediocina A e o fragmento N15 devem se ligar à bicamada lipídica de maneira semelhante. Além disso, experimentos de cinética de vazamento de carboxifluoresceína evidenciaram que o fragmento N15 da Pediocina A não é o responsável pelo rompimento de membranas lipídicas, diferentemente do que ocorre com a pediocina A. Esses dois resultados reforçam a hipótese de que praticamente todo o N-terminal da pediocina A é responsável pela ancoragem do peptídeo na superfície da bicamada lipídica [14].

A figura 6 apresenta algumas informações da Pa-1. Esse peptídeo possui carga total de $+3,1$ a pH 7,0, muito menor que a plantaricina, que apresenta uma carga total de +7 , neste mesmo pH (seção 1.1.2). Seu ponto isoelétrico é 8,7. A pediocina A possui uma grande quantidade de resíduos hidrofóbicos e é por isso que sua hidrofilicidade média é negativa. 
peptídeos nem sempre é uma tarefa simples e envolve um grande custo. Portanto, quanto menor a quantidade de resíduos que ele possuir, menor será a dificuldade, custo e tempo para sintetizá-lo.

Esse peptídeo possui 35 resíduos, sendo constituído pela região $\mathrm{N}$ - terminal da pediocina A (resíduos 1 a 18) que, como vimos na seção anterior, seria responsável pelo ancoramento inicial do peptídeo na membrana, e pela região C - terminal da plantaricina 149 (resíduos 6 a 22). As seqüências desses dois peptídeos e a do peptídeo híbrido estão apresentadas abaixo. Em vermelho estão os resíduos da região $\mathrm{N}$ - terminal da pediocina $\mathrm{A}$ e em azul, a região que constitui o C - terminal da plantaricina 149. A seqüência do peptídeo híbrido, constituída a partir das regiões vermelha e azul, está apresentada logo a seguir.

\section{KYYGNGVTCGKHSCSVDWGKATTCIINNGAMAWATGGHQGNHKC}

$$
\text { Pediocina A (PA-1) - } 44 \text { aminoácidos }
$$

\section{YSLQMGATAIKQVKKLFKKKGG}

Plantaricina 149 (pln 149) - 22 aminoácidos

\section{KYYGNGVTCGKHSCSVDWGATAIKQVKKLFKKKGG}

Peptídeo híbrido linear (híbrido) - 35 aminoácidos

O peso molecular do peptídeo híbrido, estimado a partir da seqüência de aminoácidos é de 3787,5 g/mol. O peptídeo estudado nesse trabalho está em sua versão linear, ou seja, seus dois resíduos de cisteínas (C) estão bloqueados, impedindo a formação de pontes S-S entre eles. Sua versão cíclica não foi estudada neste trabalho devido à grande dificuldade em sintetizá-la, pois, quando as cisteínas não estão bloqueadas, as pontes S-S se formam ao acaso e é muito comum que elas sejam formadas entre as cisteínas de dois peptídeos distintos, formando agregados [16].

Foi determinado pelo grupo da Professora Dra. Georgina Tonarelli que esse peptídeo é ativo em alguns tipos de bactérias, em especial em L. monocytogenes e L. seeligeri. A MIC desse peptídeo foi determinada através da mesma técnica utilizada para a obtenção da MIC da plantaricina $149 \mathrm{a}$, sendo de $338 \mu \mathrm{M}$ para L. monocytogenes. Novamente esse valor foi muito superior ao esperado e a justificativa se mantém a mesma da MIC da plantaricina 149a [7, 15]. Os testes realizados com eritrócitos mostraram que esse peptídeo não possui atividade hemolítica em concentrações entre 25 e $80 \mu \mathrm{M}$, o que novamente evidencia uma seletividade desse peptídeo frente a membranas de bactérias. O modo de ação também foi avaliado para esse peptídeo, através de experimentos de quantidade de células viáveis da bactéria L. monocytogenes. 
Resultados similares aos da plantaricina 149a (item 1.1.2) foram obtidos, mostrando que esse peptídeo também é bactericida [15].

Através de um sítio de predição de estrutura secundária de proteínas (http://www.predictprotein.org) [18] foram obtidas as probabilidades de cada região desse peptídeo formar $\alpha$-hélice, folha $\beta$ ou uma outra estrutura. Como as duas cisteínas estão bloqueadas e esse programa não permite esse tipo de inferência, elas foram trocadas por duas serinas (S). Essa é uma troca bastante utilizada quando se pretende linearizar um peptídeo cíclico, pois esses dois aminoácidos possuem estruturas similares [17]. A figura 7 apresenta essa predição, onde a escala de probabilidade, que cada aminoácido apresenta de possuir uma dada estrutura secundária, varia entre 0 e 1 . A escala em vermelho $\left(\mathrm{pH}_{-} \mathrm{sec}\right)$ está relacionada com a probabilidade de formação de $\alpha$-hélice, a escala azul (pE_sec), com a probabilidade de formação de folha $\beta$ e a escala verde ( $\mathrm{pL} \_$sec), com a probabilidade de formação de estrutura que não é nem $\alpha$-hélice e nem folha $\beta$.

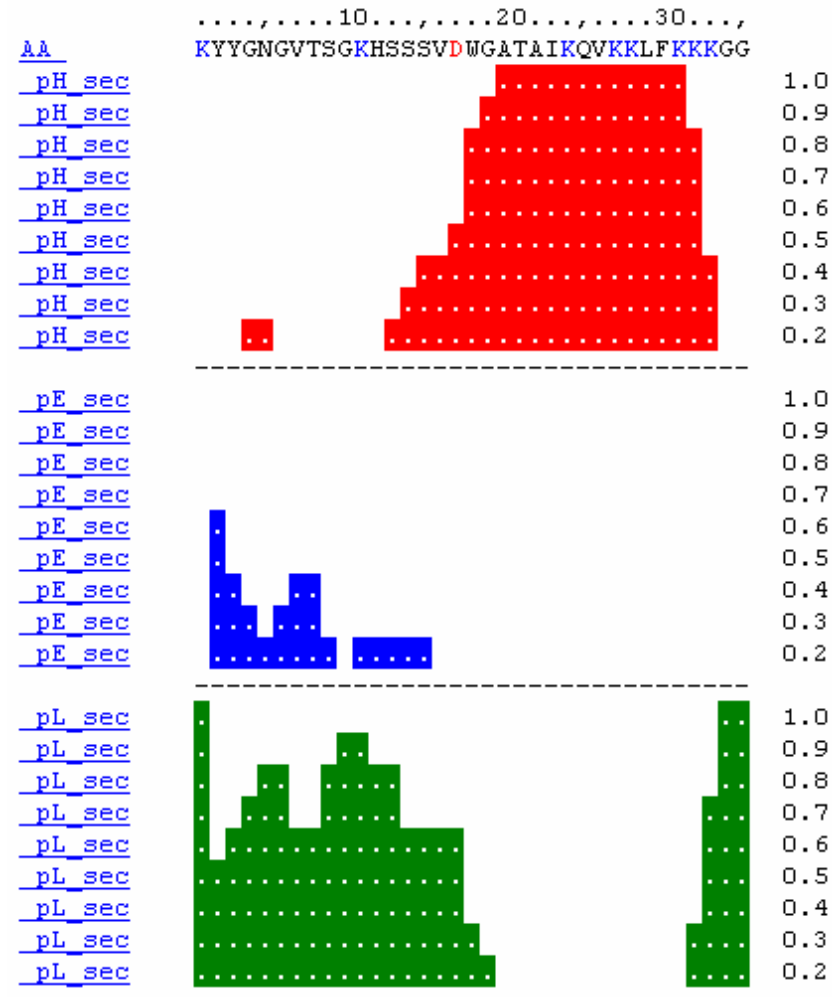

Figura 7 - Predição da estrutura secundária do peptídeo híbrido. Nessa seqüência de aminoácidos as duas cisteínas foram substituídas por serinas, para linearizar o peptídeo. A escala varia entre 0 e 1,0 e quanto maior for esse número, maior é a probabilidade de cada aminoácido estar em determinada conformação. A escala em vermelho é referente à formação de $\alpha$-hélice e é indicado, também, pelas 
siglas $p H \_s e c$. A escala em azul(pE_sec) está relacionada com a probabilidade de formação de folha $\beta e$ a verde ( $\left.p L \_s e c\right)$, com a formação de outras estruturas. Nessa representação os aminoácidos em azul (K) são positivos e o em verme lho (D) é negativo. Figura gerada e extraída de [18].

Portanto, percebemos novamente que a seqüência de aminoácidos extraída da plantaricina tem grande probabilidade de formar $\alpha$ - hélice, enquanto que a da pediocina tem probabilidade de formar folha $\beta$ ou outras estruturas secundárias.

Por fim, a figura 8 apresenta um quadro com diversas informações do peptídeo híbrido. $\mathrm{O}$ interessante é notar que o peptídeo híbrido possui maior valor de carga total, sendo de $+8 \mathrm{em} \mathrm{pH}$ 7, em relação a plantaricina 149a e pediocina A, sendo que suas características são mais parecidas com as da plantaricina 149a.

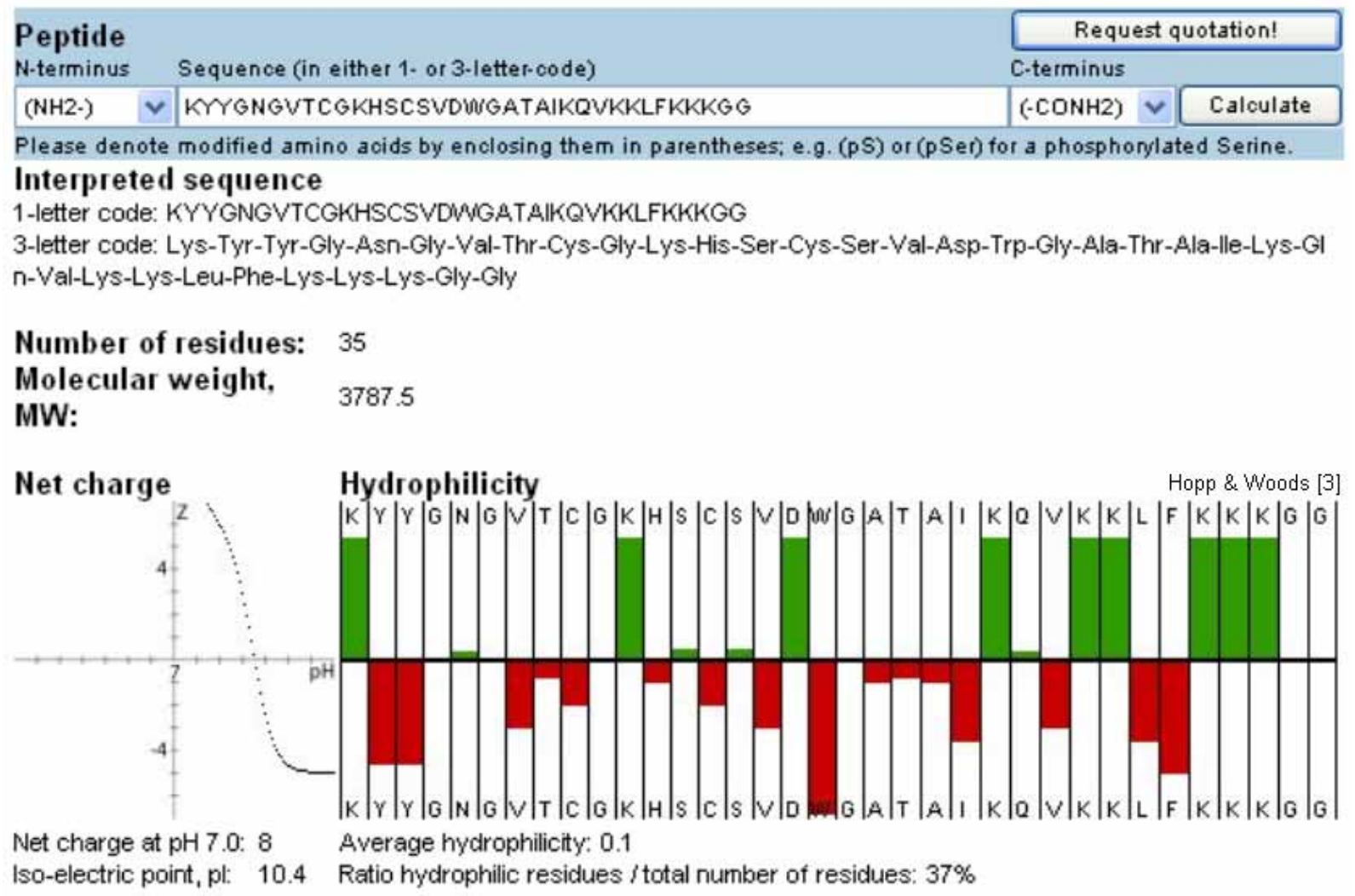

Figura 8 - Informações diversas sobre o peptídeo híbrido linear. Esse quadro foi gerado por [11] a partir da seqüência de aminoácidos da cadeia peptídica. 


\subsection{Membranas modelo: quais tipos são relevantes para o estudo?}

As membranas celulares são consideradas um marco histórico no processo seletivo, além de mediar a comunicação celular. Por esses motivos elas têm sido alvo de vários estudos da moderna biologia celular, que vão desde a determinação da composição de sua estrutura [19], interações com proteínas de membrana [20], transporte extra e intracelular [21] e outros sistemas fundamentais como a fusão entre as membranas [22].

Os processos biológicos geralmente envolvem vários eventos complexos. Por isso, é preferível estudar eventos independentes e controlados, utilizando sistemas simplificados, que contenham características fundamentais e conhecidas. O modelo mais simples de uma membrana biológica é uma bicamada lipídica, formando uma vesícula lipídica.

As vesículas lipídicas podem ser preparadas de diversas maneiras e, dependendo do método de preparo, elas podem ter diâmetro entre $10 \mathrm{~nm}$ e $100 \mu \mathrm{m}$. Muitos estudos relevantes foram realizados utilizando vesículas unilamelares pequenas (SUVs - diâmetro inferior a 100 $\mathrm{nm}$ ) e grandes (LUVs - diâmetro entre 100 e $500 \mathrm{~nm}$ ). Porém, na última década, as vesículas unilamelares gigantes (GUVs - diâmetro entre 10 e 100 m) ganharam atenção crescente [23].

As LUVs e GUVs apresentam muitas diferenças entre si, além da diferença óbvia no tamanho. A quantidade de fosfolipídeos utilizada para a fabricação de LUVs é muito maior que para a fabricação de GUVs. Utilizar muito lipídeo pode ser visto como algo negativo, principalmente devido ao gasto que isso pode gerar. Porém, são as LUVs que possibilitam a realização de várias medidas espectroscópicas e a obtenção de dados quantitativos, como por exemplo, a relação lipídeo/peptídeo em uma solução. Para a fabricação de GUVs, por outro lado, é necessário uma quantidade muito pequena de lipídeo ( 16 $\mu \mathrm{L}$ de uma solução $\mathrm{a} \sim 2 \mathrm{mM}$ ). Apesar da dificuldade de obter dados quantitativos com GUVs, sua grande vantagem é a possibilidade de visualizá-las através de um microscópio óptico, observando, por exemplo, o que ocorre com a membrana lipídica no momento da injeção de uma solução de peptídeos ou detergentes em suas vizinhanças.

Essas vesículas, na maioria dos casos, podem ser fabricadas com diferentes composições lipídicas. Isto é fundamental quando o interesse é mimetizar membranas reais, que são compostas por uma mistura de vários lipídeos. O objetivo deste trabalho é entender a interação entre o peptídeo híbrido, que possui carga total positiva, e as membranas lipídicas. Para isso, foram 
utilizados, na maior parte dos experimentos, lipídeos com cabeça polar zwiteriônica (PC fosfatidilcolina), negativa ( $\mathrm{PG}$ - fosfatidilglicerol) e neutra (colesterol). Com esses fosfolipídeos foi possível estudar membranas com diferentes porcentagens de cargas na superfície, possibilitando, assim, investigar o efeito de diferentes quantidades de cargas superficiais no processo de interação peptídeo - membrana. Além disto, membranas de bactérias possuem cerca de $25 \%$ de lipídeos negativos em sua superfície [24, 25], e as membranas de eritrócito de mamíferos são compostas, majoritariamente, por PC e colesterol.

\subsection{Objetivos}

Objetivo geral: estudar a interação de um peptídeo híbrido, sintetizado a partir da plantaricina 149 e pediocina A, com membranas fosfolipídicas.

Objetivos específicos:

- Estudar diferentes modelos de membranas lipídicas, para testar o possível efeito de carga negativa na superfície da membrana, além de mimetizar membranas celulares;

- Utilizar a técnica de dicroísmo circular para avaliar a possível interação do peptídeo híbrido com membranas lipídicas, através das modificações da estrutura secundária do peptídeo híbrido;

- Utilizar a técnica de fluorescência do triptofano para avaliar a interação do peptídeo híbrido com membranas lipídicas;

- Quantificar a relação peptídeo/lipídeo mínima para a formação de poros em diferentes membranas lipídicas através do acompanhamento da cinética de vazamento da carboxifluoresceína (molécula fluorescente) encapsuladas em LUVs;

- Investigar a ação desse peptídeo em membranas lipídicas através da visualização de GUVs por um microscópio óptico.

\subsection{Estrutura da Dissertação}

O capítulo inicial deste trabalho introduz o tema da dissertação ao leitor. Nele foram tratados dois assuntos centrais: peptídeos e membranas lipídicas. Foi feita uma introdução geral 
sobre peptídeos antimicrobianos e sobre o peptídeo a ser estudado neste trabalho. Em relação às membranas lipídicas, foram apresentados quais tipos de vesículas serão estudadas nesse trabalho.

O segundo capítulo descreve os materiais e toda a metodologia utilizada para o desenvolvimento da dissertação. Nele é descrito como foram feitas as GUVs e LUVs, além da explicação das quatro diferentes técnicas utilizadas nesse trabalho. São elas: dicroísmo circular, fluorescência, cinética de vazamento de carboxifluoresceína e microscopia óptica.

Os resultados experimentais, com subseqüente discussão, foram organizados em dois capítulos: dados obtidos com as técnicas espectroscópicas no terceiro capítulo, e observações realizadas com o microscópio óptico no quarto capítulo. Este último também contém estudos com detergentes e GUVs, realizados para aprendizado e testes iniciais com o sistema de micropipetas acoplado ao microscópio óptico que será descrito ao longo da dissertação.

O quinto capítulo apresenta as conclusões desse trabalho e as perspectivas futuras. 


\section{Materiais e Métodos}

\subsection{Materiais}

\subsubsection{Materiais e Equipamentos Utilizados}

Segue abaixo uma lista de materiais e equipamentos utilizados durante o trabalho. Eles estão separados por técnicas utilizadas:

\section{a. Para as medidas de Dicroísmo Circular}

Lipídeos para a fabricação de LUVs: DPPC e DPPG

Mini extrusor Avanti Polar Lipids (kit 610000)

Seringas de vidro Hamilton ${ }^{\circledR}$

Solução tampão: Hepes $(10$ mM, pH 7,4)

Cubeta de quartzo retangular de caminho óptico de $1 \mathrm{~mm}$

Jasco J-815 CD Spectrometer - Equipamento do Grupo de Biofísica Molecular "Sérgio Mascarenhas", IFSC, sob a responsabilidade da profa. Dra. Leila Beltramini

b. Para as medidas de fluorescência compreendendo a cinética de vazamento da carboxifluoresceína e sondagem de triptofano

Lipídeos para a fabricação de LUVs: Egg-PC, Egg-PG e colesterol

Solução tampão: Tris-HCl (10 mM, pH 7,4)

Carboxifluoresceína (Sigma Aldrich)

Coluna de Sephadex - G25

Espectrofluorímetro Hitachi F-2000 - Equipamento do Laboratório de Sistemas Biomiméticos, IQUSP, sob responsabilidade da Professora Dra. Iolanda Cuccovia

c. Medidas de Microscopia óptica

Lipídeos para a fabricação de GUVs: POPC, POPG e colesterol

Glicose e sacarose

Marcador fluorescente de membrana DilC $_{18}-1,1^{\prime}$-dioctadecyl-3,3,3',3'tetramethylindocarbocyanine perchlorate (Molecular Probes)

Multímetro digital 
Placas condutoras de FTO (fluor titanium oxide - óxido de fluor-titânio) da FlexiTec Eletronica Orgânica

Gerador de funções digital, MFG 4202, Minipa

Microscópio invertido Zeiss Axiovert 200, equipado com diferentes objetivas (aumento de 10, 20, 40 e 63X) e com filtros para excitação em 365, 395, 450 - 490 e 546 nm e câmera Zeiss AxioCam HS (High Speed) - Equipamento instalado no Laboratório de Cristalografia do IFUSP

Microscópio Leica DMR, equipado com duas objetivas (aumento de 10 e 63X) e câmera digital: Diagnostic Instruments, NDIAG 1800 - Equipamento do grupo $\mathrm{M}^{3}$ : Membranes and Microforces, Institut Charles Sadron, Strasbourg, França, sob responsabilidade do Dr. Carlos Marques

Porta amostra com entrada lateral e espaçadores de teflon, fabricado pela oficina do Departamento de Física Aplicada do IFUSP

Micropipetas de vidro

Lâminas e lamínulas de vidro

Micropipetadores (10 e $1000 \mu \mathrm{L}$ - Nichyrio) e ponteiras

\subsubsection{Fosfolipídeos}

Diversos lipídeos foram utilizados para a fabricação das membranas modelo. Eles foram comprados da Avanti Polar Lipids (http://www.avantilipids.com) [26], com exceção do Egg-PC, que foi extraído da gema do ovo e gentilmente cedido pela Professora Dra. Iolanda Midea Cuccovia, do Laboratório de Sistemas Biomiméticos, no Instituto de Química da USP.

Os lipídeos escolhidos possuem cabeças zwiteriônicas (PC), carregados negativamente (PG) ou neutros (colesterol). A escolha por esses lipídeos se deu a partir da composição de membranas celulares de mamíferos (compostas, basicamente, por PC e colesterol) e da composição de membranas de bactérias (que contém cerca de 25\% de lipídeos negativos).

Nas figuras abaixo estão apresentados os lipídeos utilizados nesse trabalho. Os dois primeiros lipídeos apresentados são o DPPC e o DPPG. Eles foram utilizados para as a fabricação de LUVs de diferentes composições, para as medidas de dicroísmo circular, descritas na seção 2.2.4. 


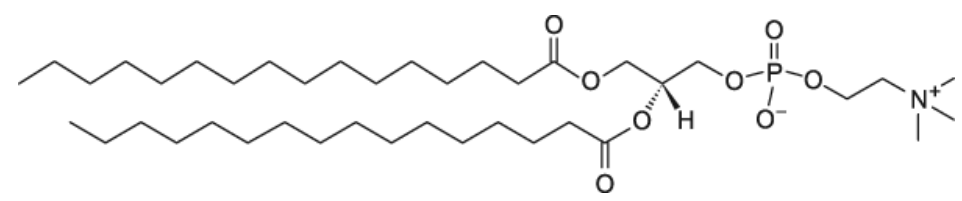

Figura 9 - Estrutura de DPPC (1,2-Dipalmitoil-sn-Glicero-3-Fosfatidilcolina). Figura extraída de [26].

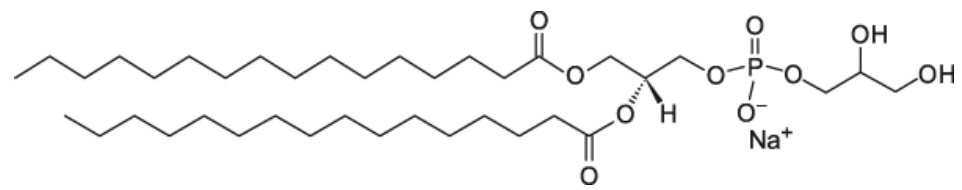

Figura 10 - Estrutura de DPPG (1,2-Dioleoil-sn-Glicero-3-[Fosfo-rac-(1-glicerol)]). Figura extraída de [26].

Os três próximos lipídeos são o POPC, POPG e o colesterol. Eles foram utilizados para a fabricação de GUVs e o colesterol também foi utilizado para a preparação de LUVs para medidas de vazamento de carboxifluoresceína, explicado a seguir na seção 2.2.1.

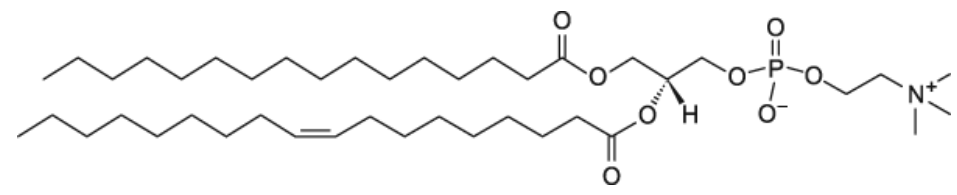

Figura 11 - Estrutura do POPC (1-Palmitoil-2-Oleoil-sn-Glicero-3-Fosfatidilcolina)). Figura extraída de [26].

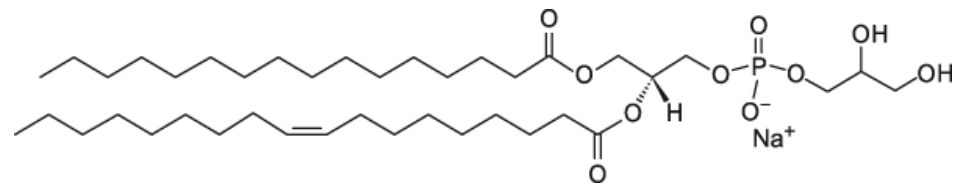

Figura 12 - Estrutura do POPG (1-Palmitoil-2-Oleoil-sn-Glicero-3-[Fosfo-rac-(1-glicerol)]). Figura extraída de [26].

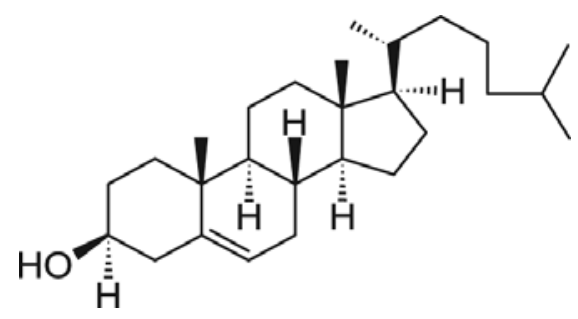

Figura 13 - Estrutura do colesterol. Figura extraída de [26]. 
Os dois últimos lipídeos são o egg-PC e o egg-PG. Eles são constituídos por uma mistura de lipídeos, que possuem a mesma cabeça polar, mas diferentes cadeias acilas. Majoritariamente eles apresentam caudas de palmitoil (16 carbonos com nenhuma insaturação) e de oleoil (18 carbonos e uma insaturação). Assim, são compostos, em sua grande maioria por DPPC, DPPG, POPC, POPG, DOPC, DOPG. As vesículas constituídas com esse fosfolipídeo são as membranas que melhor mimetizam as membranas biológicas, pois elas também são constituídas por uma mistura de diferentes lipídeos.

A tabela 2 apresenta dados de temperatura de transição de fase da fase gel para a líquida cristalina (ou fluida) e peso molecular dos lipídeos utilizados nesse trabalho. Esses dados foram retirados do sítio do fabricante dos lipídeos (http://www.avantilipids.com) [26].

\begin{tabular}{|c|c|c|}
\hline Lipídeos & $\begin{array}{c}\text { Peso Molecular } \\
(\mathrm{g} / \mathrm{mol})\end{array}$ & $\begin{array}{c}\text { Temperatura de } \\
\text { Transição de fase }\left({ }^{\circ} \mathrm{C}\right)\end{array}$ \\
\hline DPPC & 734,05 & 41 \\
\hline DPPG & 744,96 & 41 \\
\hline POPC & 760,09 & -2 \\
\hline POPG & 771,00 & -2 \\
\hline Colesterol & 386,65 & - \\
\hline Egg-PC & $760,09 *$ & - \\
\hline Egg-PG & $771,00 * *$ & - \\
\hline
\end{tabular}

Tabela 2 - Temperatura de transição da fase gel para a fase fluída e peso molecular dos lipídeos utilizados nesse trabalho, os valores em branco significam temperaturas muito baixas. *Valor atribuído com base no peso molecular do POPC $e^{* *}$ Valor atribuído com base no peso molecular do POPG. Valores extraídos de [26].

Embora tenham sido utilizados diferentes lipídeos para a realização dos experimentos, nós acreditamos que a interação inicial ocorra devido à atração eletrostática entre o peptídeo, que é positivo, e a cabeça polar dos lipídeos, que pode ser zwiteriônica (PC) ou negativa (PG). 


\subsection{Métodos}

\subsubsection{Preparação das Vesículas Unilamelares Grandes (LUVs)}

O processo de obtenção de LUVs consiste em algumas etapas (figura 14). Ele se inicia com a formação de um filme lipídico no fundo de um tubo de ensaio através da evaporação de uma soluçãosão de lipídeos em solvente orgânico, normalmente o clorofórmio.

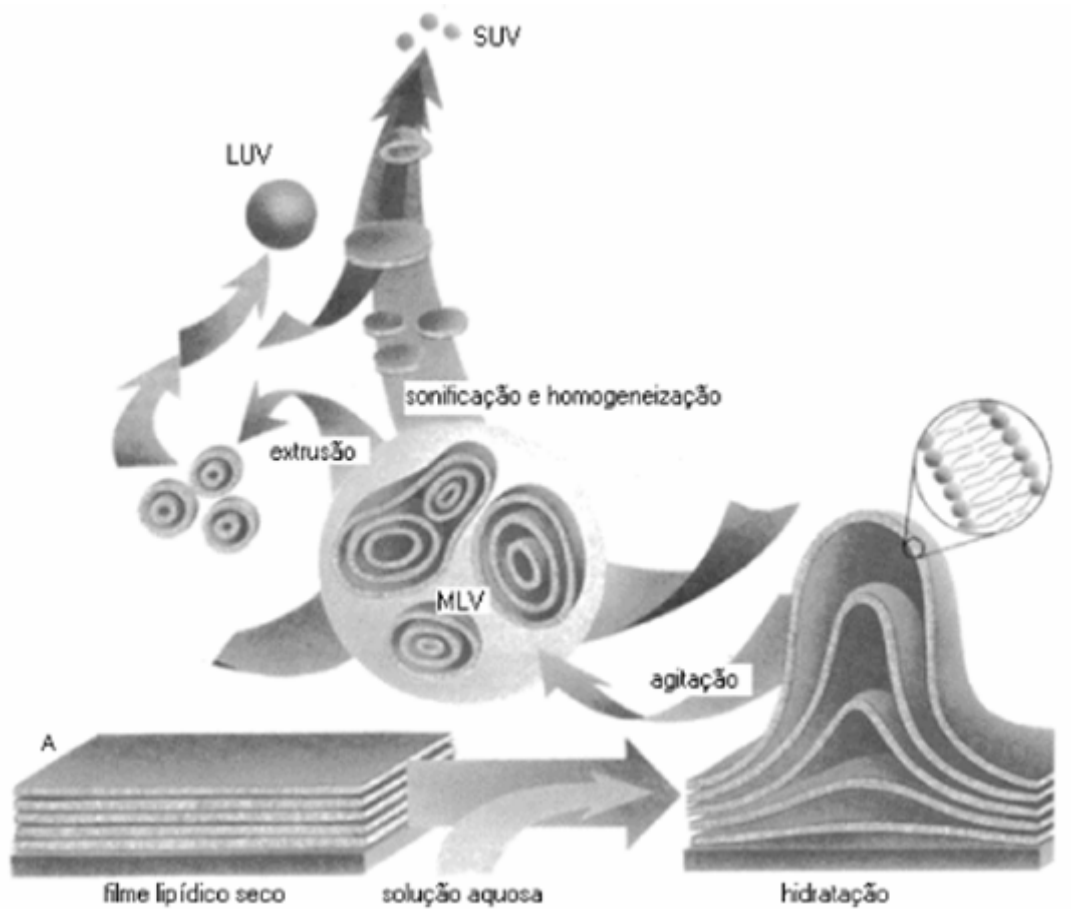

Figura 14 - Representação esquemática da obtenção de LUVs e SUVs. Figura extraída de [26].

Para que não haja resíduo do solvente, o filme permanece no vácuo por cerca de 12 horas. Logo em seguida é feita a sua suspensão em uma solução aquosa - nesse trabalho foram utilizados dois tampões: o Hepes e o Tris $\mathrm{HCl}$, ambos a $10 \mathrm{mM}$ e $\mathrm{pH} 7,4 \mathrm{pH}$ do meio físiológico). Nessa etapa as vesículas são multilamelares. Para que as membranas se tornem unilamelares e de tamanho definido (com uma certa dispersão) a solução deve ser extrusada [27]. Para isso, a solução é colocada em uma seringa e forçada a atravessar uma membrana sintética que tem a função de um filtro. Essa montagem permite o controle da temperatura, que deve ser superior à temperatura de transição de fase do lipídeo. O extrusor utilizado neste trabalho foi o da Avanti Polar Lipids Inc., como o da figura 15, com membranas de $100 \mathrm{~nm}$. No caso de medidas com $\mathrm{CD}$, utilizamos o tampão Hepes $(10 \mathrm{mM}, \mathrm{pH} 7,4)$, pois na concentração utilizada e na faixa 
de comprimento de onda em que as medidas foram realizadas $(190-250 \mathrm{~nm})$, ele não interfere nas medidas de $\mathrm{CD}$ [32]. As amostras foram extrusadas a $45{ }^{\circ} \mathrm{C}$, acima da temperatura de transição de fase do DPPC e do DPPG (tabela 2).

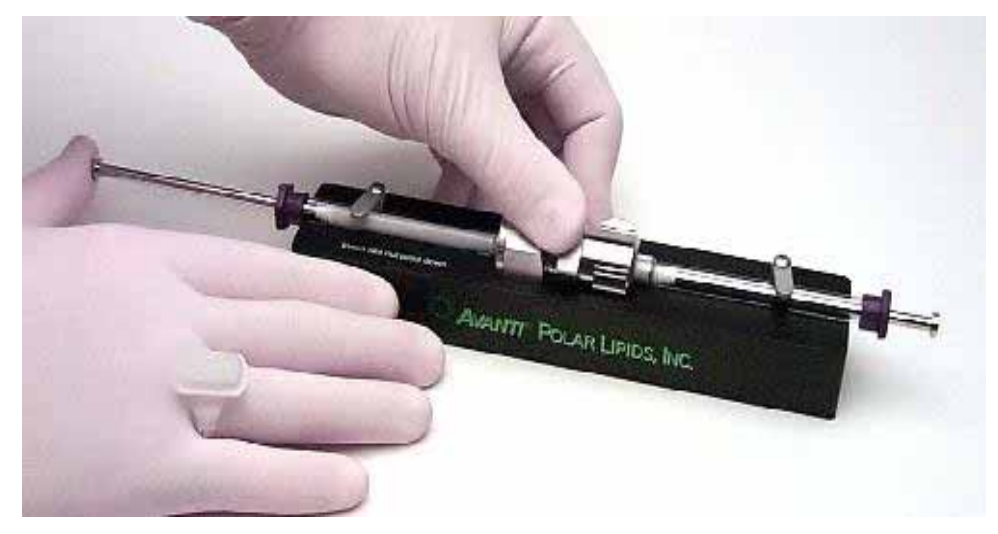

Figura 15 - Extrusor utilizado para a obtenção de LUVs. Figura extraída da referência [26].

Após a passagem da solução, por cerca de 11 vezes, pela membrana do extrusor, as LUVs estão prontas. Foram realizadas medidas de espalhamento de luz dinâmico confirmando um diâmetro médio de $100 \mathrm{~nm}$.

Em determinada etapa do estudo (seção 2.2.5.2) encapsulamos carboxifluoresceína (CF obtida de Sigma Aldrich, com estrutura apresentada na figura 16), em diferentes LUVs, para acompanhar sua cinética de vazamento nas membranas e inferir sobre a seletividade na interação das mesmas com o peptídeo.

\section{Equação 1}

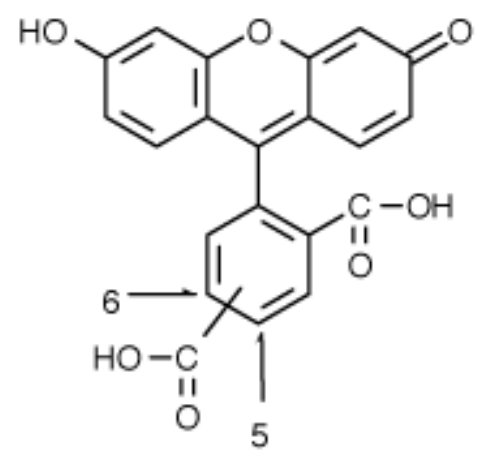

Figura 16 - Estrutura da 5(-6)Carboxifluoresceína (CF).Figura extraída de [28] 
Para encapsular a CF é necessário que ela seja adicionada à solução tampão no momento da hidratação do filme. Após a extrusão é necessário que a CF livre (não encapsulada) seja retirada através da passagem da solução em uma coluna de Sephadex - G25, hidratada com o mesmo tampão utilizado na hidratação do filme [29]. As membranas são retiradas no volume vazio $\left(\mathrm{V}_{0}\right)$ da coluna (dimensão: $0,8 \mathrm{~cm}$ de diâmetro e $20 \mathrm{~cm}$ de altura), que deve ser inicialmente saturada com o tampão utilizado. No nosso caso, utilizamos Tris $\mathrm{HCl}(10 \mathrm{mM}, \mathrm{pH} 7,4)$ como tampão, com $300 \mathrm{mM}$ de $\mathrm{NaCl}$. Isto porque além de mimetizarmos o meio fisiológico, que contém cerca de $150 \mathrm{mM}$ de sal, ele também é necessário para manter o balanço de força iônica, evitando o rompimento da membrana devido à diferença de pressão osmótica entre sua parte interior e exterior [29]. No estudo de fluorescência do triptofano, as LUVs também foram preparadas com a solução tampão Tris $\mathrm{HCl}$. Todo este procedimento foi realizado no Laboratório de Sistemas Biomiméticos, no Instituto de Química da USP, sob a supervisão da Dra. Katia Regina Perez Daghastanli.

\subsubsection{Preparação das Vesículas Unilamelares Gigantes (GUVs)}

A técnica utilizada para a preparação das GUVs é a eletroformação [30]. Esse processo se inicia com o espalhamento de cerca de 16 microlitros da solução lipídica em clorofórmio $(2 \mathrm{mg} / \mathrm{mL})$ em duas placas de vidros condutoras, recobertas com ITO (indium tin oxide - óxido de índio estanho), como na figura 17a. O substrato é deixado por algumas horas no vácuo para a total remoção do solvente orgânico. Em seguida, com um espaçador de teflon $(\sim 2 \mathrm{~mm})$ e graxa de silicone (b), a cela é fechada (c) e o espaço livre preenchido com uma solução de interesse (d). Para acelerar o crescimento das vesículas o arranjo é submetido a um campo AC de $1 \mathrm{~V}$ de amplitude e uma freqüência de $10 \mathrm{~Hz}$ (e). Em pouco tempo (entre uma e três horas) as vesículas estão formadas e possuem uma dispersão grande no tamanho, com uma variação no diâmetro entre 10 e $100 \mu \mathrm{m}$. 

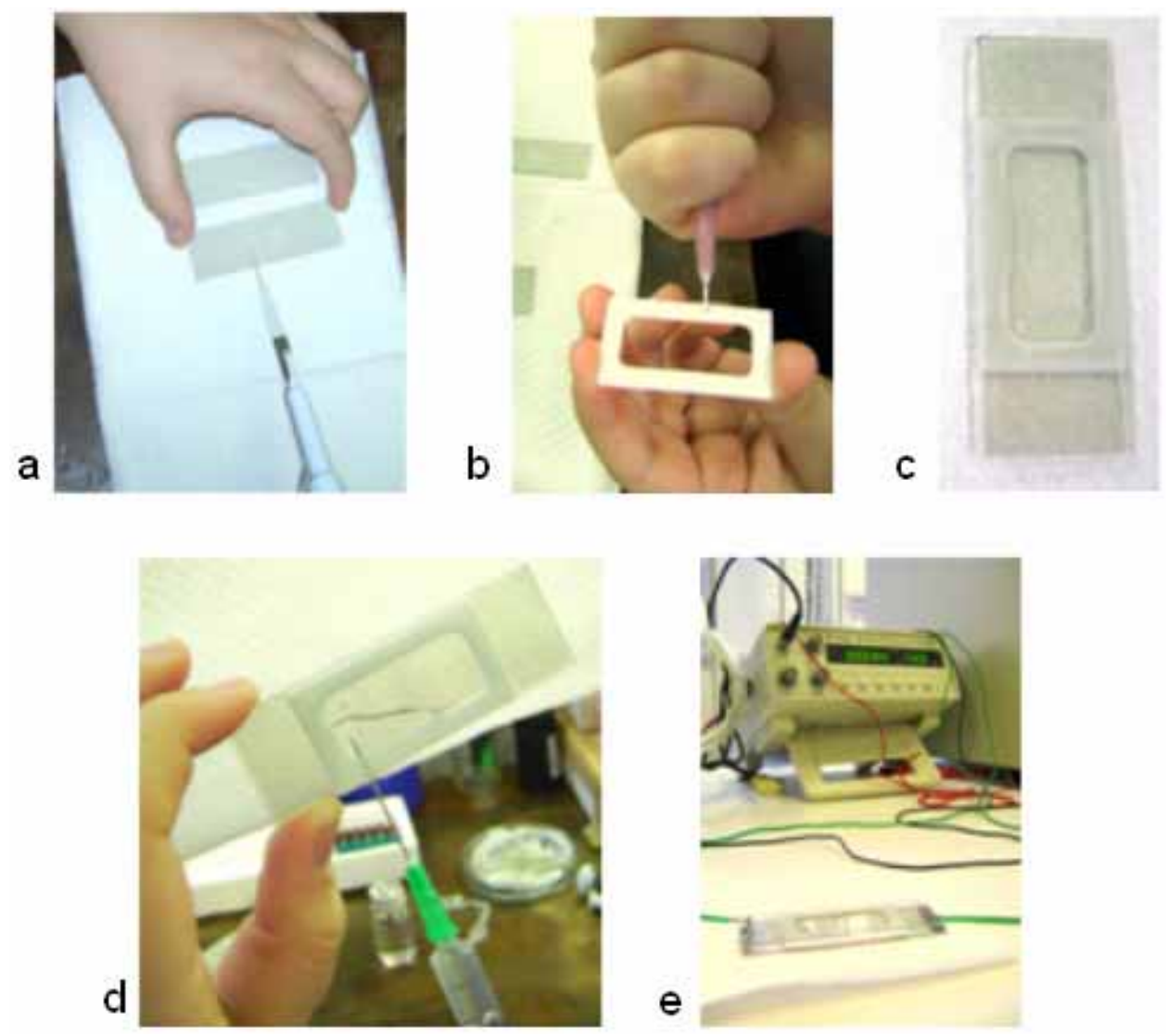

Figura 17 - Esquema das etapas da fabricação de GUVs pelo método de eletroformação.

As vesículas são crescidas em uma solução de tampão Hepes-glicose/sacarose e diluídas cerca de 10 vezes em uma solução de tampão Hepes-sacarose/glicose; essas soluções devem ser isotônicas para evitar poros na bicamada devido à diferença de pressão osmótica. A assimetria de açúcar, além de facilitar a visualização das GUVs no microscópio, devido à diferença entre seus índices de refração, é responsável pela estabilização das vesículas no fundo da cela de visualização do microscópio invertido, pois a glicose e a sacarose possuem densidades diferentes. A sacarose é um dissacarídeo, ou seja, é mais denso que a glicose, que é um monossacarídeo. Para as medidas com um microscópio invertido, onde a amostra é visualizada pela parte de baixo, é necessário que as GUVs sejam crescidas em uma solução contendo sacarose e diluídas em uma solução contendo sacarose, assim elas ficarão mais pesadas que o meio onde estão e irão se assentar no fundo da cela de observação. A concentração de açúcar utilizada em todas as experiências foi de 0,2 molar. 
As GUVs podem ser observadas por um microscópio óptico através de diferentes modos de visualização (seção 2.2.3). Em um desses modos, o de fluorescência, é necessário que uma molécula fluorescente esteja presente na solução ou na membrana, para possibilitar a visualização pelo microscópio óptico. Nesse trabalho foi utilizado um marcador de membrana, o $\mathrm{DilC}_{18},\left(1,1^{\prime}\right.$ dioctadecyl-3,3,3',3' -tetramethylindocarbocyanine perchlorate - obtido de Molecular Probes). Este marcador de membrana tem seu máximo de absorção em $544 \mathrm{~nm}$ e emite em $565 \mathrm{~nm}$. O DilC $_{18}$ foi incorporado em pequena quantidade ( $1 \mathrm{~mol} \%$ ) na solução lipídica que foi colocada na placa de ITO, antes de ocorrer o crescimento das GUVs. Por possuir uma estrutura similar à estrutura de um lipídeo (figura 18), o DilC 18 terá preferência por ficar na bicamada lipídica. No experimento utilizamos um filtro que possui $\lambda_{e x}=546 \mathrm{~nm}$ e observamos em um comprimento de onda superior a $560 \mathrm{~nm}$.

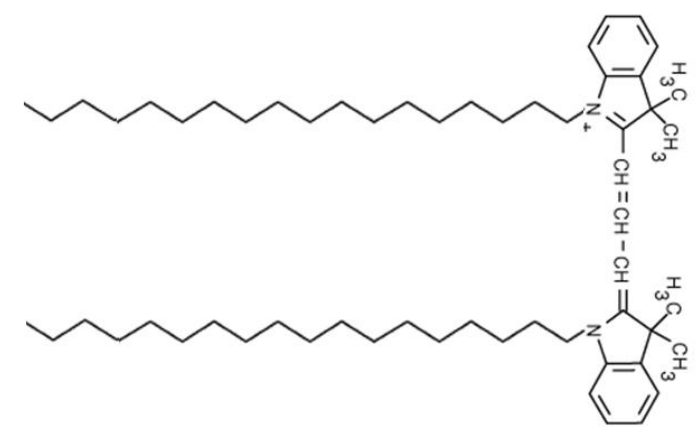

Figura 18 - Estrutura do DilC18. Marcador fluorescente de membranas lipídicas que tem seu máximo de absorção em um comprimento de onda de $544 \mathrm{~nm}$ e de emissão em $565 \mathrm{~nm}$.

\subsubsection{Microscopia Óptica}

Neste trabalho foram utilizados dois microscópios ópticos diferentes. Um Zeiss Axiovert 200 invertido, utilizado nas medidas do Brasil e um microscópio direto Leica DMR, que foi utilizado nas medidas realizadas no ICS - Institut Charles Sadrom, (Strasboug, França), sob a responsabilidade dos Drs. Carlos Marques e André Schroder, dois pesquisadores do grupo $M^{3}$ : Membranes and Microforces. Apesar desses dois microscópios possuírem algumas diferenças, o princípio de funcionamento é o mesmo. Eles usam luz halógena e um sistema de lentes que possibilitam a visualização de uma imagem ampliada da amostra. Esse é o modo de visualização chamado de transmissão. Porém, eles ainda permitem outras formas de visualização da amostra, 
como, por exemplo, o contraste óptico, a fluorescência e o RICM (Reflection Interference Contrast Microscopy - Microscopia de Interferência Reflexiva).

Os quatro modos de visualização citados acima foram utilizados neste trabalho. As imagens que esses modos permitem realizar são bem diferentes (figura 19). A figura 19a mostra uma GUV vista pelo modo de transmissão campo claro. É importante notar que, apesar de serem preparadas com a assimetria de açúcares, a cor de dentro e de fora da membrana é a mesma. Já a figura 19b mostra a GUV visualizada pelo modo de contraste de fase, onde os tons de cinza de dentro e de fora das GUVs são diferentes. A figura 19c mostra a imagem de uma GUV que foi marcada com o $\mathrm{DilC}_{18}$, e visualizada no modo fluorescência $\lambda_{e x}=546 \mathrm{~nm}$. Note que apenas a membrana apresenta fluorescência, o que indica que o marcador realmente tem preferência pela bicamada lipídica. Nesses três modos de visualização, a imagem obtida pelo microscópio óptico é do equador das membranas (linhas tracejadas da figura 20). E, por fim, a figura 19d mostra a imagem de um GUV vista pelo modo de RICM. Utilizando esse modo de visualização o que conseguimos analisar é a interface GUV - lamínula. A imagem é feita através do uso de interferência óptica: a GUV é iluminada através da superfície com que tem contato, ou seja, através da lamínula; os raios que são refletidos pela GUV interferem com os raios que são refletidos pela lamínula e as franjas de interferência podem ser visualizadas, dando origem aos anéis de Newton [31], quando a GUV está rígida e esférica.
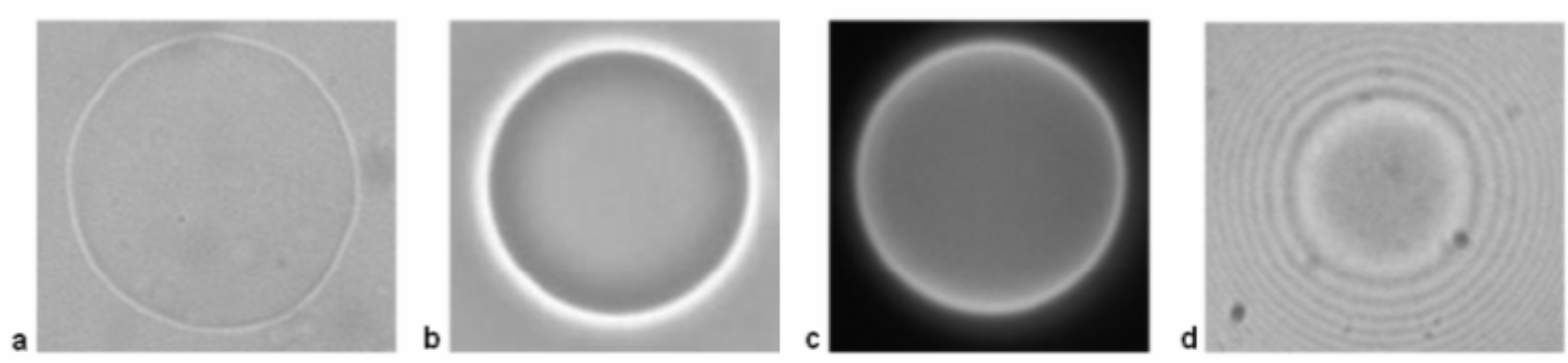

Figura 19 - Diferentes modos de visualização de vesículas gigantes com um microscópio óptico. Em (a) temos uma GUV visualizada pelo modo de transmissão, em (b) temos a visualização pelo modo de contraste de fase, em (c) o modo de fluorescência e em (d) o RICM. 


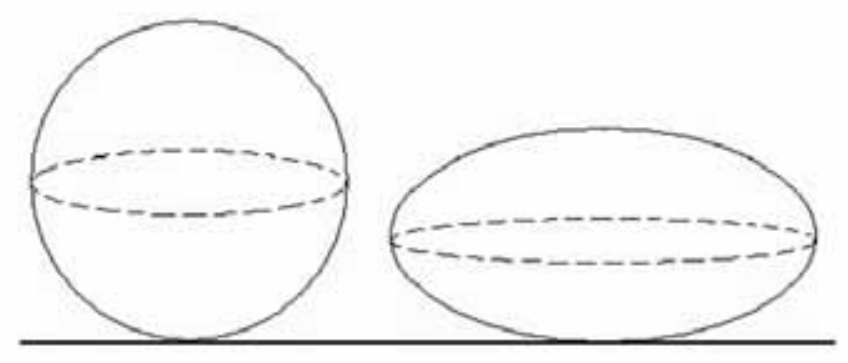

Figura 20 - O microscópio óptico visualiza o equador das GUVs, ele é indicado pela linha tracejada dessa figura.

O microscópio Zeiss, utilizado neste trabalho, possui um sistema de micropipeta acoplado (Sutter Instrument), que foi implementado ao longo do ano de 2007. Esse sistema permite que, através de uma micropipeta de vidro, uma solução seja injetada nas vizinhanças das GUVs, enquanto que estas são observadas pelo microscópio óptico. Isso permite que qualquer alteração na bicamada lipídica, devido a essa injeção, seja observada e gravada. O sistema de injeção está representado na figura 21.
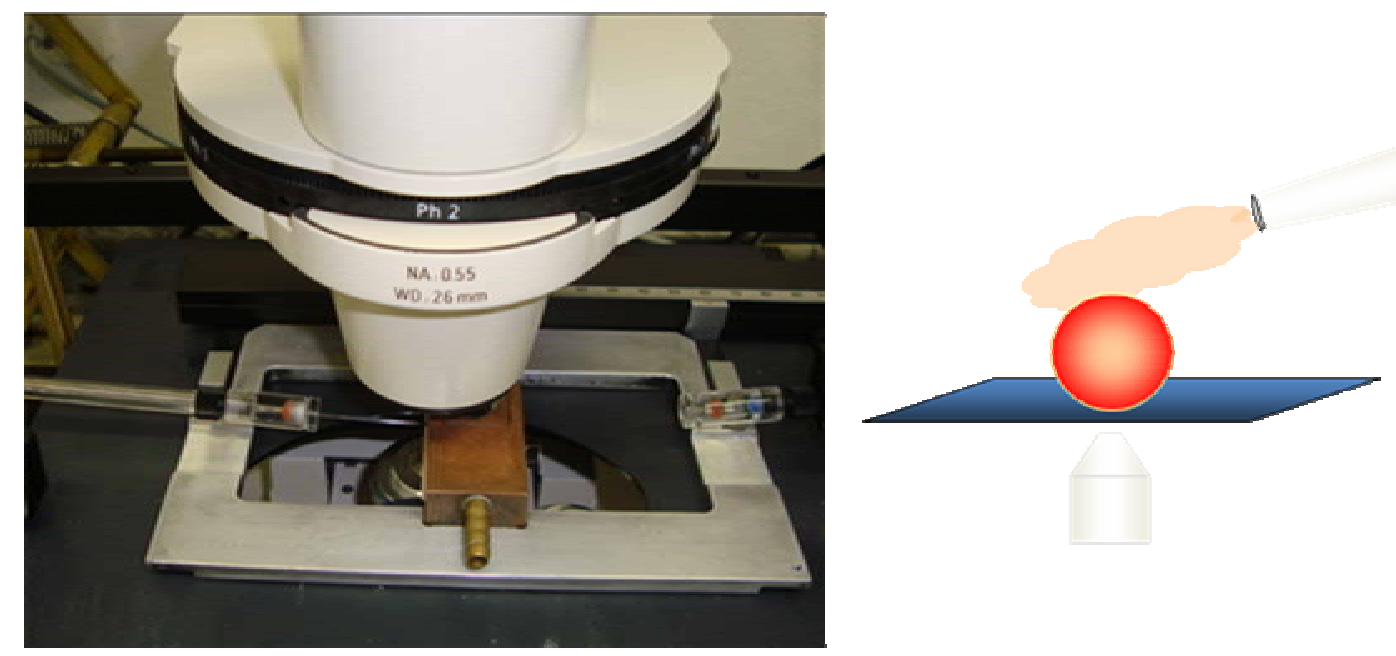

Figura 21 - Representação esquemática da injeção de solução ao redor das GUVs. A GUV é representada pelo circulo vermelho, a solução está em laranja, a lamínula em azul, a micropipeta em cinza e a objetiva em verde.

Como o sistema de micropipetas foi implementado pelo grupo, foram realizados vários testes com detergentes (SDS e Triton X-100) antes da utilização do peptídeo. Esses testes resultaram em um trabalho paralelo a esse. Os resultados obtidos estão apresentados na seção 4.2. 


\subsubsection{Dicroísmo Circular}

O dicroísmo circular (CD) é uma técnica estrutural valiosa. Através dela é possível obter informações sobre a estrutura secundária de macromoléculas, como proteínas, peptídeos e ácidos nucléicos [32]. Essas macromoléculas são compostas por muitos centros quirais, que são unidades opticamente ativas que interagem com a luz incidente e alteram sua polarização.

O dicroísmo é o fenômeno onde a absorção da luz circularmente polarizada por um centro quiral é diferente para diferentes direções de polarização. Uma luz plana polarizada pode ser vista como a união de duas componentes circularmente polarizadas, de magnitudes iguais e que giram em sentidos opostos: uma no sentido anti-horário (left handed, L) e outra no sentido horário (right handed, R), como ilustrado na figura 22. Quando essa luz passar pela amostra, dois fenômenos podem acontecer:

a) as componentes $\mathrm{R}$ e $\mathrm{L}$ não são absorvidas ou são absorvidas com as mesmas proporções. Isto fará com que a recombinação entre $\mathrm{R}$ e L esteja no plano original e nenhum sinal de CD seja registrado;

b) existirá uma diferença entre a absorção das duas componentes e isso fará com que o sinal de CD seja diferente de zero. A figura 22 ilustra a diferença entre os itens a) e b).
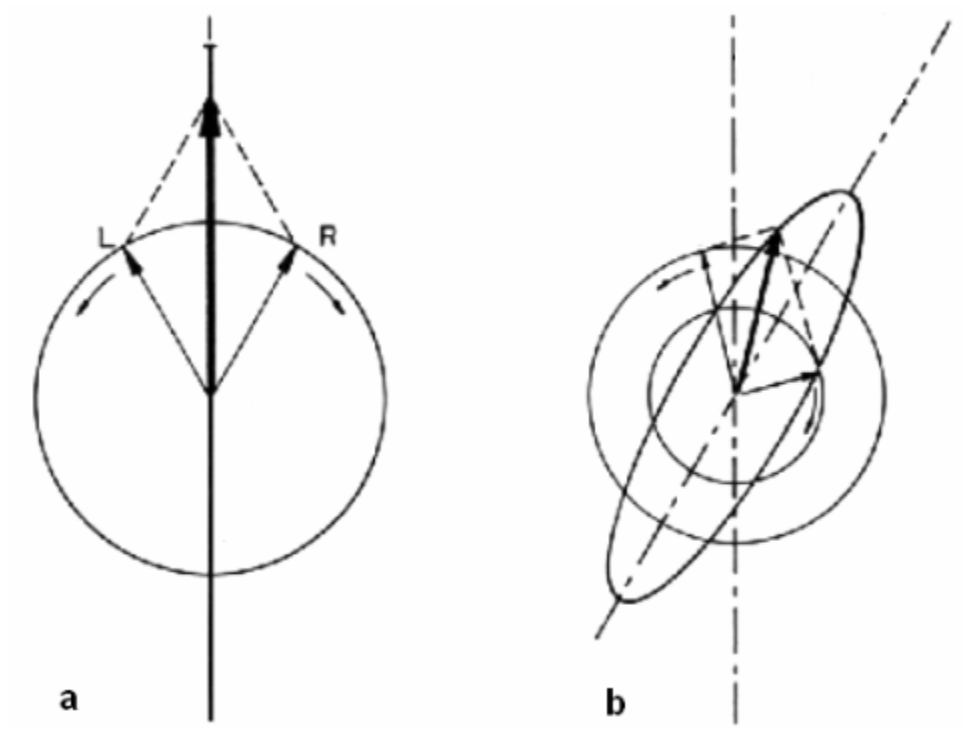

Figura 22 - A origem do sinal de CD. Em a) não há diferença nas amplitudes entre as componentes $L$ e $R$. Em b) essa diferença existe devido à absorção preferencial por uma das componentes, o que resultará em um sinal de CD diferente de zero. Figura extraída de [33]. 
Alguns equipamentos de CD medem a diferença na absorção (A) entre as duas componentes R e L, expressa pela equação 1, onde os índices são referentes a cada componente da luz circularmente polarizada [34]. Porém, outros equipamentos já apresentam os dados em termo da elipticidade dicróica $([\theta])$. Esta pode ser definida pela seguinte relação: $\tan ^{-1} \theta=b / a$, onde a razão $b / a$ é a relação entre o menor e o maior eixo da elipse da Figura 22.b.

$$
\Delta A(\lambda)=A_{L}(\lambda)-A_{R}(\lambda) \quad \text { Equação } 2
$$

Os dados de CD podem ser apresentados tanto em diferença de absorbância quanto em elipticidade dicróica. O mais comum é apresentá-los normalizados, em termos das unidades repetidas do peptídeo, como apresentado na equação 2, onde L é o caminho óptico da cubeta, em $\mathrm{cm}$, c é a concentração de peptídeo utilizada, em mg/mL e PMR é dado pela razão entre o peso molecular do peptídeo e a quantidade de ligações peptídicas [32]. Esse valor para o peptídeo híbrido é de $\sim 111 \mathrm{~g} / \mathrm{mol}$.

$$
[\theta]_{P M R}=\frac{P M R \cdot[\theta]}{\text { L.C. } 10} \quad \text { Equação } 3
$$

Através de alguns algoritmos, tais como o Selcon, CDSSTR e Contin, que constituem o pacote CDPro [35], é possível estimar a estrutura secundária de proteínas a partir do espectro experimental de CD [36]. Esses softwares fazem a comparação entre o espectro experimental e os espectros de um banco de dados, que são de proteínas com estruturas resolvidas. Mas um ponto que deve ser levado em consideração para este trabalho é que nenhum banco de dados possui espectros de peptídeos com estrutura resolvida. Este fato impede a utilização desses algoritmos para a análise das curvas, a não ser que o espectro seja predominantemente de alguma estrutura secundária [32].

As diferentes formas do espectro de $\mathrm{CD}$, que são referentes às possíveis diferentes estruturas secundárias de proteínas, estão apresentadas na Figura 23. A curva apresentada com a linha contínua representa o espectro característico de estrutura tipo $\alpha$ - hélice, apresentando duas bandas negativas em 208 e $222 \mathrm{~nm}$ e uma banda positiva em $198 \mathrm{~nm}$. O espectro que representa estrutura desordenada está em linhas tracejadas pequenas, apresentando uma banda negativa com mínimo em torno de $198 \mathrm{~nm}$. 
O equipamento utilizado para a realização desse experimento é um JASCO J-815. As medidas foram realizadas com uma cubeta de quartzo, de caminho óptico de $1 \mathrm{~mm}$, em temperatura controlada de $25^{\circ} \mathrm{C}$. Todos os espectros apresentados nesta seção foram gravados depois do acúmulo de 16 scans, de 190 a $250 \mathrm{~nm}$. O espectro das vesículas em solução tampão (branco) foi subtraído de todas as curvas.

Este trabalho foi realizado com a colaboração do Sr. José Luiz de Souza Lopes e da Profa . Dra. Leila Beltramini, do Grupo de Biofísica Molecular "Sérgio Mascarenhas", do Instituto de Física de São Carlos.

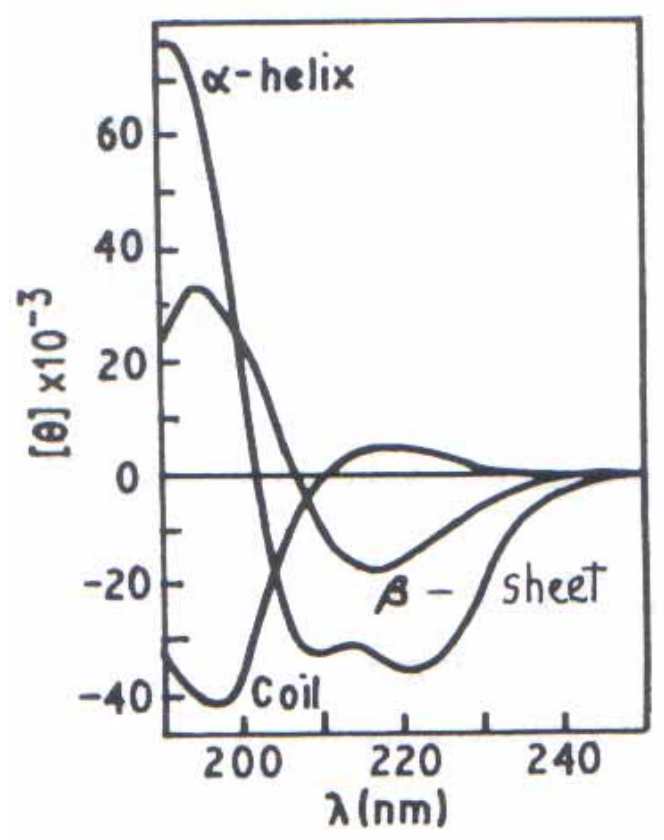

Figura 23 - Espectro de CD de $\alpha$ - hélice ( $\alpha$ - helix), folha - $\beta$ ( $\beta$-sheet) e estrutura desordenada (Randon - Coil ou Coil) formadas pelo polipeptídio poli-L-lisina. Figura extraída de [37].

\subsubsection{Espectroscopia de Fluorescência}

Fluorescência é a técnica que detecta a radiação emitida por uma molécula quando esta passa do primeiro estado singlete excitado $\left(S_{1}\right.$ - representado na figura 24) para o estado fundamental. Quando se excita uma molécula, que está no seu estado fundamental $\left(\mathrm{S}_{0}\right)$, ela irá para qualquer nível vibracional de um estado excitado. Em seguida essa molécula começará a perder energia, na forma de calor, passando pelos níveis vibracionais ou fazendo conversões 
internas (setas amarelas), até atingir o vibracional de menor energia. Quando ela se encontra nesse estado, três fenômenos podem ocorrer:

a) A molécula perderá energia suficiente, através da emissão de um fóton, para voltar ao estado fundamental. Este é o fenômeno da fluorescência, representado pela seta vermelha.

b) A molécula passará para um estado tripleto excitado $\left(T_{1}\right)$, através de um cruzamento intersistema (seta azul escura), sendo que quando atingir o nível vibracional de menor energia $\left(\mathrm{T}_{1}\right)$ ela poderá fosforescer (seta rosa) ou perder energia de uma forma não radiativa (seta azul clara). Nos dois casos a molécula voltará para o estado fundamental $\left(\mathrm{S}_{0}\right)$.

c) A molécula perderá energia de uma forma não radiativa, ou seja, não emitirá nenhum fóton e retornará para o estado fundamental (seta laranja).

Esses três fenômenos competem entre si e o que se espera é que prevaleça o que possuir o menor tempo de vida [38]. Todos esses fenômenos estão representados no diagrama de Jablonski (figura 24), que também nos fornece a informação de tempo de vida de cada um deles.

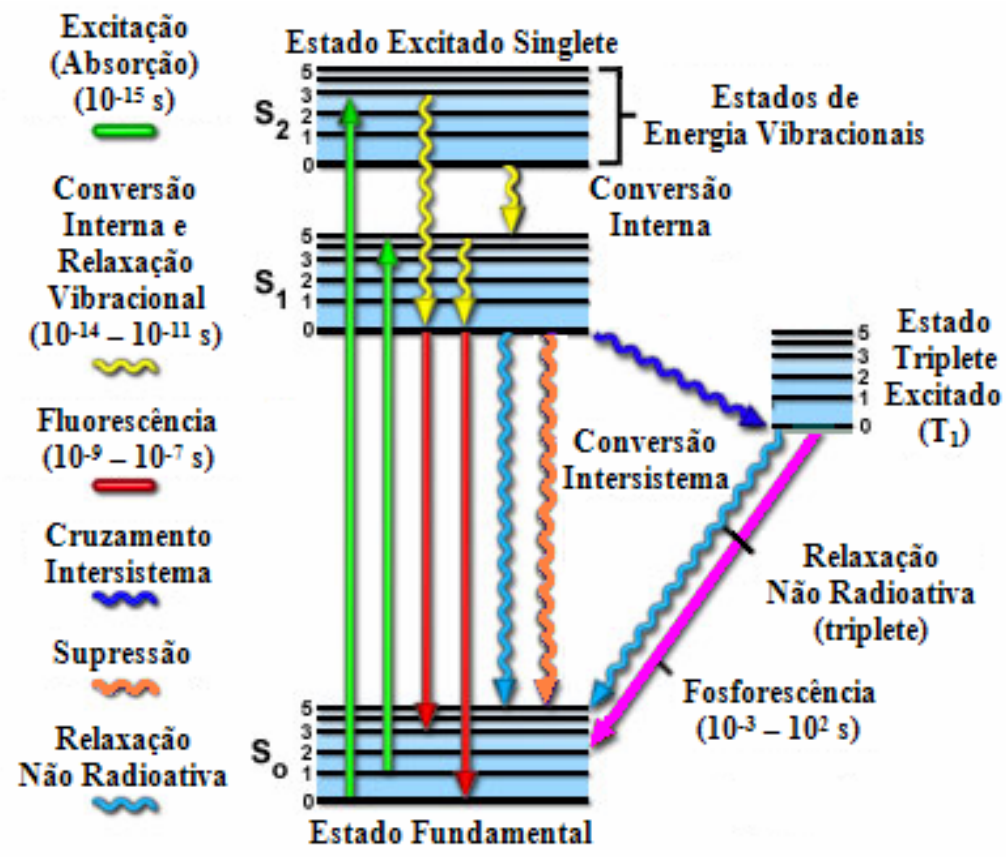

Figura 24 - Diagrama de Jablonski. Estão representados os processos de absorção e relaxação de uma molécula e seus tempos característicos. Figura extraída e modificada de [39].

Neste trabalho, a espectroscopia de fluorescência foi utilizada com dois diferentes enfoques. No primeiro, ela foi utilizada para sondar a fluorescência do triptofano (aminoácido 
fluorescente presente no peptídeo híbrido), na presença de LUVs de diferentes composições lipídicas. No segundo, ela foi utilizada para acompanhar a cinética de vazamento da carboxifluoresceína, quando encapsulada em diferentes tipos de membranas. Esses dois casos estão descritos abaixo.

\subsubsection{Sondagem da Fluorescência do Triptofano (W)}

O triptofano é um aminoácido fluorescente que está presente no peptídeo híbrido estudado neste trabalho (ver seção 1.1.4). Quando excitado em $\lambda_{\mathrm{ex}}=280 \mathrm{~nm}$ ( $\lambda$ de máxima absorção), ele emitirá um espectro muito bem determinado, com seu máximo de emissão em $\lambda_{e m}=353 \mathrm{~nm}$ (água, $\mathrm{pH}$ neutro) [38].

O comprimento de onda referente ao máximo de emissão da fluorescência de um fluoróforo nos dá informação sobre sua vizinhança. Um fenômeno conhecido é o deslocamento da banda de emissão de fluorescência de fluoróforos dependendo do meio em que ele se encontra. De um modo bem simples, esse fenômeno ocorre também devido à mudança de constante dielétrica $(\varepsilon)$ do meio onde o fluoróforo se encontra. A constante dielétrica de um solvente é uma medida relativa de sua polaridade. Por exemplo, a água, que é um solvente muito polar, possui constante dielétrica relativa de $\sim 80$, enquanto que o clorofórmio, que é muito mais apolar que a água, possui constante dielétrica relativa de $\sim 5$ [38]. Quando o fluoróforo passa de um meio para outro (com constante dielétrica diferente), essa diferença irá refletir na diferença de energia de absorção e emissão e, conseqüentemente, no comprimento de onda de emissão do fluoróforo. $\mathrm{Na}$ prática quando uma molécula fluorescente está em um meio aquoso (muito polar, $\varepsilon$ alto) e é levada para um meio com polaridade mais baixa ( $\varepsilon$ baixo), o espectro de emissão de fluorescência sofrerá um desvio para $\lambda$ menores. Esse fenômeno é conhecido por deslocamento para o azul (blue shift). Caso a molécula passe de um meio apolar para um meio polar (ou menos apolar), o efeito que será observado é conhecido como desvio para o vermelho (red shift), ou seja, o espectro de emissão de fluorescência sofrerá um deslocamento para comprimento de onda maior. Também é esperado que quanto mais rígida for a estrutura do peptídeo (contendo triptofano), maior seja a intensidade de sua fluorescência. Com a estrutura mais rígida os aminoácidos perdem menos energia vibrando ou rotacionando, por exemplo, refletindo, assim, em um aumento da intensidade de fluorescência do triptofano [38]. 
Essa técnica é utilizada para investigar a afinidade de ligação (binding) entre o peptídeo e a membrana, além de possibilitar a inferência sobre o meio do triptofano do peptídeo [40].

A emissão da fluorescência do triptofano foi monitorada entre 295 e $450 \mathrm{~nm}$, a uma temperatura controlada de $25^{\circ} \mathrm{C}$, por um espectrômetro de fluorescência Hitachi F - 2000. As LUVs utilizadas foram de egg-PC puro, 25:75 egg-PC:egg-PG, 50:50 egg-PC:egg-PG, 75:25 egg-PC:egg-PG, e egg-PG puro, fabricadas em tampão Tris-HCl, $10 \mathrm{mM}$, ph 7,4. A experiência foi realizada com uma cubeta de quartzo, específica para fluorescência, de caminho óptico de 10 $\mathrm{mm}$.

Esse trabalho foi realizado com a colaboração da Dra. Katia Regina Perez Daghastanli, do Laboratório de Sistemas Biomiméticos, no Instituto de Química da USP.

\subsubsection{Cinética de Vazamento de Carboxifluoresceína}

A carboxifluoresceína é uma molécula fluorescente (figura 16) que foi encapsulada em LUVs de diferentes composições lipídicas. Essa molécula se auto suprime em concentrações elevadas ( $>50 \mathrm{mM}$ ) e deve ser excitada em $\lambda_{e x}=490 \mathrm{~nm}$ e monitorada em $\lambda_{e m}=512 \mathrm{~nm}$ [41].

Com esse experimento é possível monitorar o vazamento de $\mathrm{CF}$ do interior de membranas lipídicas, pois é esperado que o peptídeo forme poros em membranas, levando-as a lise. Portanto, se isso ocorrer, o volume interno da membrana vazará para o meio externo, a concentração de CF diminuirá $(<50 \mathrm{mM})$ e a intensidade de fluorescência aumentará. Para obter a informação de porcentagem de vazamento de CF, é necessário conhecer a fluorescência máxima, ou seja, a fluorescência quando todas as membranas são rompidas. Para isso foi adicionado, ao final da experiência, $10 \mu \mathrm{L}$ de uma solução aquosa de 10\% (peso/peso) de polidodecanol, para que seja certificado o rompimento de todas as membranas. A porcentagem de vazamento da $\mathrm{CF}$ foi determinada de acordo com a equação 3 , onde $I_{f}$ é a intensidade de fluorescência final, $I_{0}$ é a intensidade de fluorescência inicial e $I_{\max }$ é a intensidade máxima, obtida após a adição do dodecanol.

$$
\text { vazamento }(\%)=\frac{I_{f}-I_{0}}{I_{\max }-I_{0}} .100 \quad \text { Equação } 4
$$

Através das curvas de porcentagem de vazamento de $\mathrm{CF}$ em função do tempo é possível obter informações sobre a dose-resposta do peptídeo híbrido. Esse gráfico consiste em relacionar, 
em um determinado tempo, a porcentagem de vazamento de CF em função da razão molar peptídeo/lipídeo. Fazendo algumas dessas curvas, em tempos diferentes, é possível avaliar a evolução do vazamento de CF das diferentes LUVs. A razão peptídeo/lipídeo será determinada como descrito abaixo, através da dosagem de fosfato.

Como já mencionado na seção 2.2.1, as vesículas passam por uma coluna Sephadex G-25 para que toda a CF não encapsulada seja retirada da solução. Neste procedimento a solução de vesículas extrusadas é diluída em um volume maior, devido às dimensões da coluna. Como apenas a solução que fica no volume vazio é retirada e utilizada, não é possível estimar a concentração final de vesículas na solução. Por isso, para que seja determinada a quantidade de lipídeos que temos na solução, é necessária a realização da dosagem de fosfato, já que as cabeças polares (PC e PG) possuem um fósforo (P) cada uma. Esta é uma técnica muito utilizada nesse tipo de situação e o protocolo está exposto no capítulo de Material e Métodos. [42]. O primeiro passo é fazer a solução padrão de fosfato $\left(\mathrm{KH}_{2} \mathrm{PO}_{4}\right)$ a $1 \mathrm{mM}$ em água. Para que seja determinada a curva padrão é necessário escolher diferentes quantidades dessa solução e proceder da seguinte forma:

- Secar a amostra (solução de vesículas) e as diferentes quantidades da solução padrão de fosfato em tubos pirex, em uma estufa a $120^{\circ} \mathrm{C}$;

- Adicionar em cada tubo 0,4 mL de ácido perclórico. Deixar por uma hora em um bloco quente a $180^{\circ}$. Esse é o tempo necessário para mineralizar totalmente o fosfato;

- Esfriar a amostra e adicionar $1 \mathrm{~mL}$ de água, 0,4 $\mathrm{mL}$ de molibdato de amônia a $1,25 \%(\mathrm{p} / \mathrm{v})$ e agitar o tubo com um vórtex;

- Em seguida, adicionar 0,4 mL de ácido ascórbico a 3\% (p/v) e novamente misturar a solução com um vórtex;

- Colocar todos os tubos em banho-maria fervente, por 10 minutos;

- Esfriar a solução e ler a absorbância em 797 nm;

Com as absorbâncias em $797 \mathrm{~nm}$ das diferentes quantidades de solução padrão de fosfato é possível levantar uma curva padrão, como exemplificado na figura 25. A equação apresentada nessa figura foi obtida através de um ajuste linear aos pontos experimentais, forçando a passagem pela origem do gráfico. A concentração de fosfato nas LUVs é determinada a partir da substituição do valor de sua absorbância em 797 nm nessa equação. 


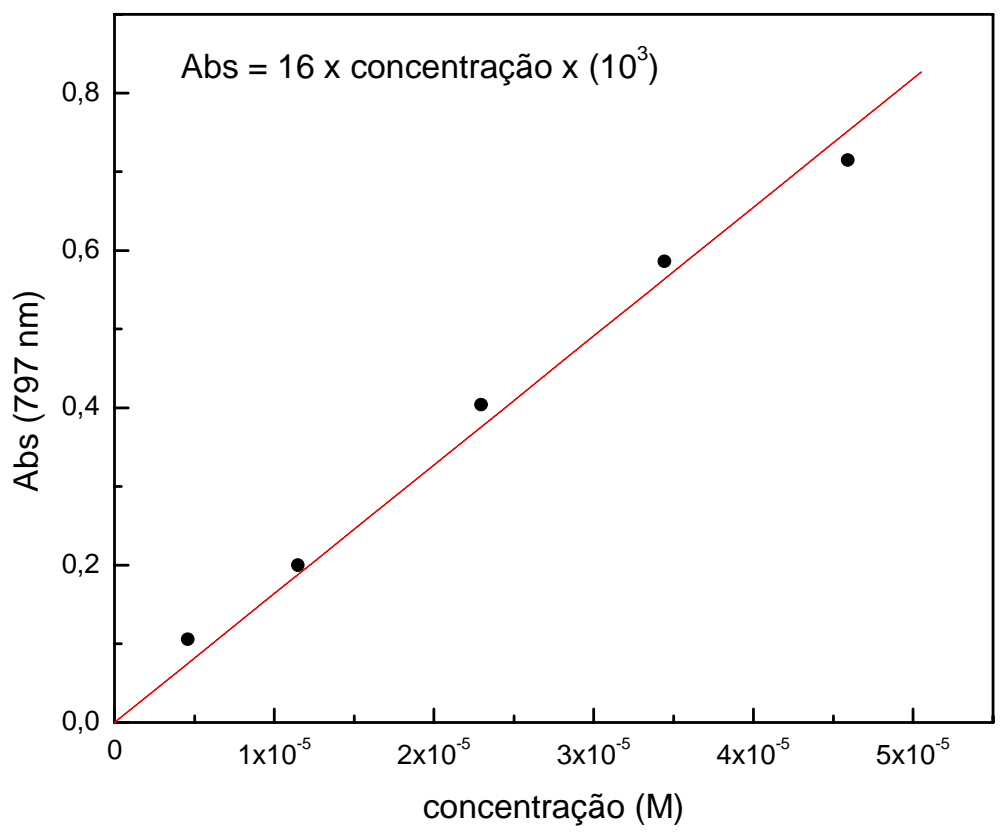

Figura 25 - Gráfico que exemplifica a curva padrão da dosagem de fosfato. A equação é ajustada aos dados experimentais, com o vínculo que a mesma deve passar pela origem das coordenadas.

A cinética de vazamento da carboxifluoresceína foi monitorada em função do tempo, por cerca de $1800 \mathrm{~s}$, a uma temperatura de $25^{\circ} \mathrm{C}$, por um espectrofluorímetro Hitachi $\mathrm{F}-2000$. A cubeta utilizada para as medidas é a mesma utilizada no item anterior: uma cubeta de quartzo, específica para fluorescência, de caminho óptico de $10 \mathrm{~mm}$.

Esse trabalho foi realizado com a supervisão da Dra. Katia Regina Perez Daghastanli, do Laboratório de Sistemas Biomiméticos, no Instituto de Química da USP. 


\section{Resultados dos Métodos Espectroscópicos e Discussões}

\subsection{Dicroísmo Circular}

O espectro de dicroísmo circular do peptídeo híbrido foi monitorado, à temperatura ambiente, na presença de cinco diferentes tipos de LUVs. Essas vesículas eram compostas por DPPC (figura 9) e DPPG (figura 10). A concentração de lipídeo utilizada foi de $\sim 2 \mathrm{mM}$. Elas foram hidratados em solução tampão Hepes, 10 mM, pH 7,4 e extrusadas para formar LUVs. A concentração de peptídeo utilizada foi de $0,2 \mathrm{mg} / \mathrm{mL}$, o que corresponde a uma concentração de $50 \mu \mathrm{M}$. Portanto, a relação peptídeo:lipídeo em todas as experiências é de $\sim 0,025$.

O primeiro passo da experiência foi medir o espectro de CD da solução tampão com vesículas (branco), que apresentou um sinal desprezível, mas mesmo assim foi subtraído de todas as curvas apresentadas abaixo. A próxima medida realizada foi a do peptídeo livre em solução tampão. Uma solução de $500 \mu \mathrm{L}$ contendo $\sim 50 \mu \mathrm{M}$ de peptídeo foi adicionada à cubeta de quartzo e mediu-se o espectro de $\mathrm{CD}$. As próximas medidas realizadas foram na presença de diferentes membranas lipídicas. Em todas elas a solução final foi de $500 \mu \mathrm{L}$, contendo $\sim 2 \mathrm{mM}$ de lipídeos e $\sim 50 \mu \mathrm{M}$ de peptídeo. As membranas utilizadas para essa experiência foram: DPPC puro, 75:25 DPPC:DPPG, 50:50 DPPC:DPPG, 25:75 DPPC:DPPG e DPPG puro.

A figura 26 apresenta os espectros de CD para o peptídeo híbrido na presença dessas diferentes LUVs. Nesta figura estão apresentados diferentes espectros, indicando que o peptídeo híbrido adota diferentes conformações em função das diferentes LUVs presentes no meio onde ele se encontra. 


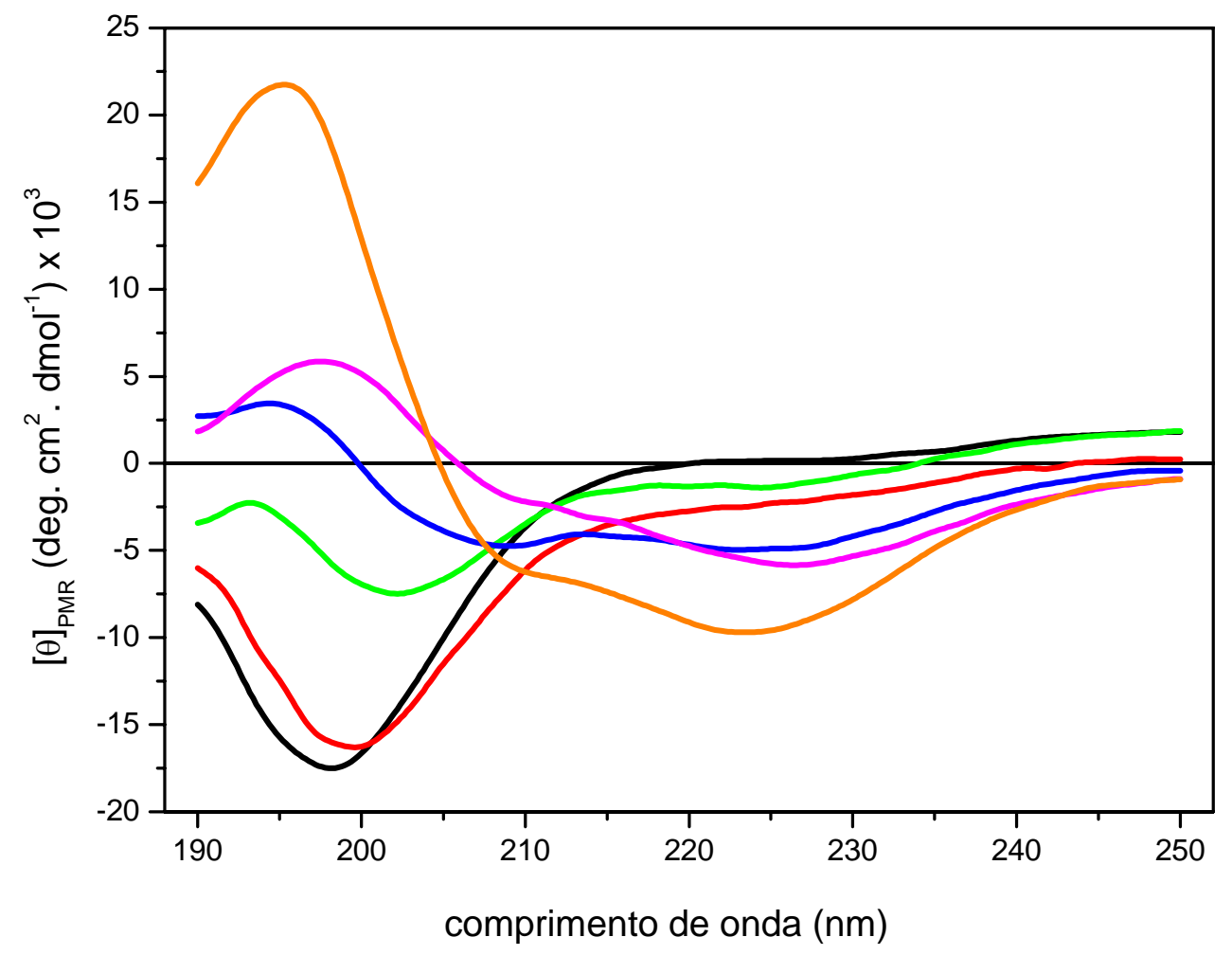

Figura 26 - Espectro de CD para a interação entre o peptídeo hibrido([50 $\mu \mathrm{M}])$ e diferentes membranas lipídicas ([2 mM]). As relações lipídicas estão apresentadas em mol\%: (一) peptídeo híbrido livre em solução tampão, (-) DPPC, (-) 75: 25 DPPC:DPPG, (-) 50:50 DPPC:DPPG, (-) 25:75 DPPC:DPPG, (-) DPPG.Relação peptídeo/lipídeo: 0,025.

Esse resultado nos mostra que a estrutura secundária do peptídeo híbrido é sensível ao tipo de membrana com a qual ele interage, pois há diferenças significativas nos espectros apresentados na figura 26. Quando em tampão, o peptídeo híbrido adota uma conformação estendida, com o espectro de CD apresentando uma banda negativa em torno de $198 \mathrm{~nm}$ (curva preta), que é característica de estrutura secundária randômica. A adição de membranas de DPPC (curva vermelha) não proporciona uma grande alteração nesse espectro. Ele ainda apresenta essa banda negativa, porém um pouco deslocada para comprimentos de onda maiores, com seu mínimo em torno de $200 \mathrm{~nm}$, além de se observar uma pequena diminuição do sinal de $[\theta]_{\mathrm{NMR}}$. Por outro lado, ao adicionarmos membranas que contém DPPG, um lipídeo negativo, o espectro muda sua forma, refletindo uma mudança conformacional de estrutura secundária desse peptídeo. O espectro de CD do peptídeo na presença de membranas compostas com $25 \mathrm{~mol} \%$ de DPPG apresenta duas bandas negativas, uma mais intensa centrada em $202 \mathrm{~nm}$ e outra a $225 \mathrm{~nm}$, mostrando que o peptídeo começa a adotar uma conformação menos flexível nestas condições 
experimentais [43, 44]. O início da banda negativa em $225 \mathrm{~nm}$ sugere que o peptídeo está iniciando a enovelar-se. Sendo assim, a presença dessas duas bandas negativas sugere a presença de duas populações, uma estendida e outra parcialmente enovelada [43, 44]. Com o aumento da quantidade de PG na membrana, a banda negativa em $225 \mathrm{~nm}$ torna-se mais pronunciada, sofrendo um deslocamento para o azul (blue shift) para membranas compostas apenas por DPPG. Neste caso o sinal de CD observado é característico de estrutura com grande quantidade de conformação helicoidal, apresentando uma banda positiva em torno de $195 \mathrm{~nm}$ e duas bandas negativas, em torno de 209 e $223 \mathrm{~nm}$. Esse espectro está próximo ao esperado para o sinal de $\alpha-$ hélice, que tipicamente apresenta uma banda positiva em $190 \mathrm{~nm}$ e duas bandas negativas em 208 e $222 \mathrm{~nm}$ [34].

Portanto, estes resultados nos dão suporte para inferir que o peptídeo adquire uma maior porcentagem de conformação helicoidal quanto maior for a carga superficial disponível na membrana, passando de uma conformação desordenada (em solução e na presença de membranas compostas por DPPC), para predominantemente helicoidal quando exposta à membranas compostas apenas por DPPG.

\subsection{Sondagem da fluorescência do triptofano}

O espectro de emissão de fluorescência do triptofano presente no peptídeo híbrido foi monitorado na presença de LUVs com diferentes cargas superficiais, à temperatura ambiente. Foram produzidas membranas compostas unicamente por egg-PC e egg-PG e três membranas mistas compostas por diferentes proporções molares desses lipídeos, nas mesmas proporções utilizadas nas medidas de CD. Todas elas foram feitas em solução tampão Tris-HCl, 10 mM, ph 7,4 .

O triptofano do peptídeo híbrido foi excitado em $280 \mathrm{~nm}$, ou seja, no seu máximo de absorção. Nesse comprimento de onda a tirosina (outro aminoácido fluorescente, presente no peptídeo híbrido), também apresenta banda de absorção. Porém sua emissão não é visualizada em nenhum dos dados apresentados, possivelmente devido à tranferência de energia da tirosina para o triptofano. [38].

O primeiro passo da experiência foi medir a fluorescência do triptofano livre na solução tampão. Na cubeta foram colocados $500 \mu \mathrm{L}$ de uma solução de peptídeo híbrido, a $1 \mu \mathrm{M}$, em tampão Tris-HCl. Após essa medida inicial foi inserida uma alíquota de $1 \mu \mathrm{L}$ de vesículas 
lipídicas, a uma concentração de $\sim 15 \mathrm{mM}$. A concentração final destas vesículas na solução de $500 \mu \mathrm{L}$ é de $\sim 30 \mu \mathrm{M}$. Em seguida mediu-se o espectro de fluorescência, sendo subtraído o espectro do tampão Tris-HCL (branco). A seguir, adicionou-se mais uma alíquota de $1 \mu \mathrm{L}$ de vesículas, perfazendo um total das mesmas em solução de $\sim 60 \mu \mathrm{M}$. Novamente mediu-se o espectro de fluorescência.

As figuras abaixo apresentam os espectros de fluorescência do triptofano na presença das diferentes membranas utilizadas. Em todos os gráficos a curva em preto representa o peptídeo livre em solução tampão. A curva em vermelho foi obtida após o inserção de $1 \mu \mathrm{L}$ de vesículas. A curva verde representa a emissão de fluorescência após a segunda inserção de vesículas.

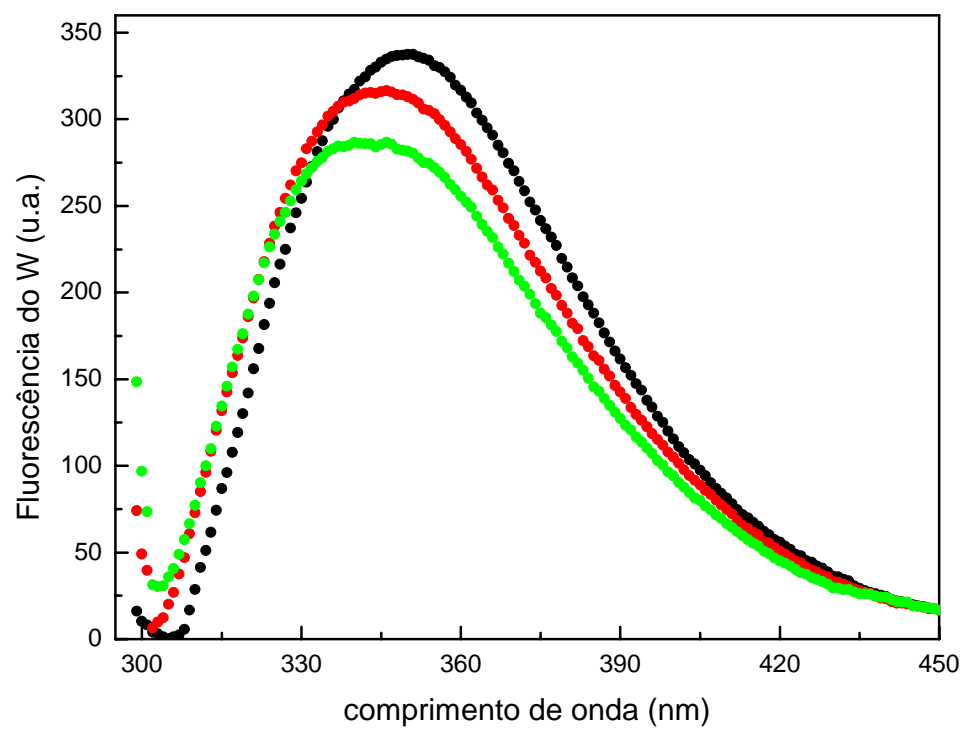

Figura 27 - Espectro de emissão de fluorescência do triptofano, presente no peptídeo híbrido linear, na presença de membranas compostas por egg-PC. Em preto está o peptídeo híbrido livre em solução tampão. A curva vermelha foi obtida após a inserção de $30 \mu \mathrm{M}$ de vesículas na solução e a verde após a inserção de $60 \mu \mathrm{M}$. 


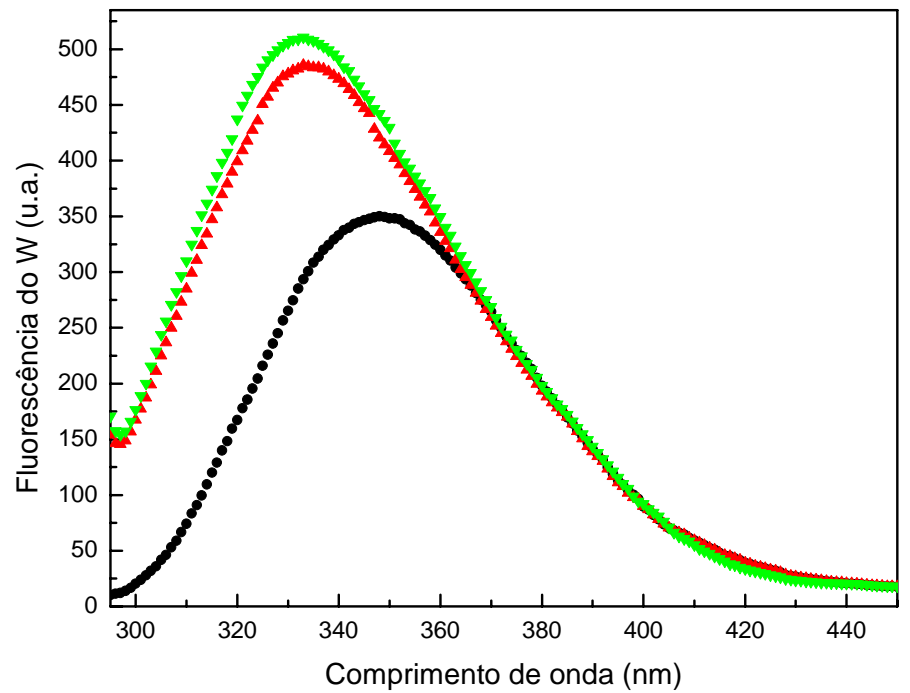

Figura 28 - Espectro de emissão de fluorescência do triptofano, presente no peptídeo híbrido linear, na presença de membranas compostas por 25:75 mol\% egg-PG:egg-PC. Em preto está o peptídeo híbrido livre em solução tampão. A curva vermelha foi obtida após a inserção de $30 \mu \mathrm{M}$ de vesículas na solução e a verde após a inserção de $60 \mu \mathrm{M}$.

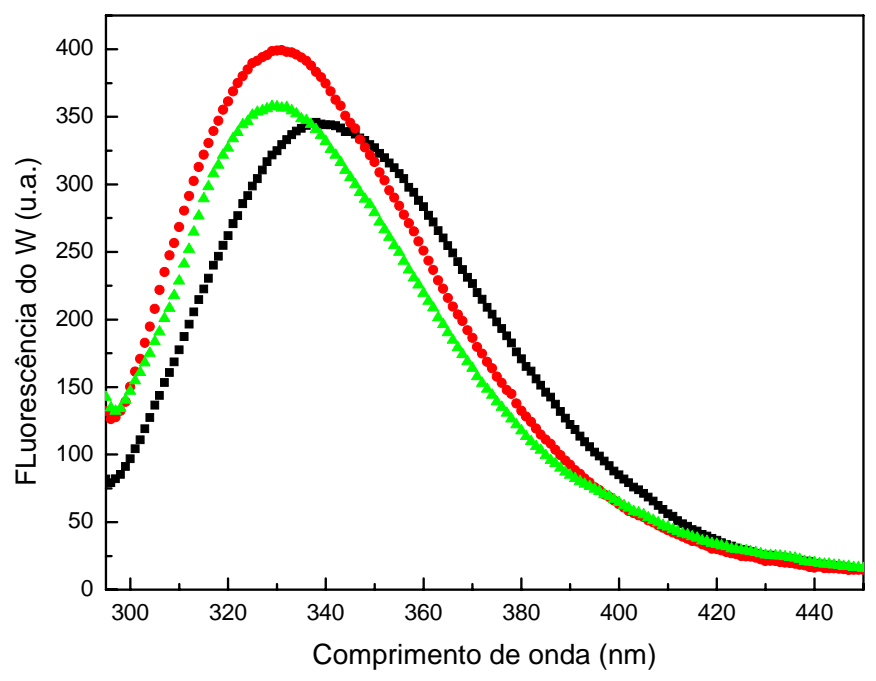

Figura 29 - Espectro de emissão de fluorescência do triptofano, presente no peptídeo híbrido linear, na presença de membranas compostas por 50:50 mol\% egg-PG:egg-PC. Em preto está o peptídeo híbrido livre em solução tampão. A curva vermelha foi obtida após a inserção de $30 \mu \mathrm{M}$ de vesículas na solução e a solução e a verde após a inserção de $60 \mu \mathrm{M}$. 


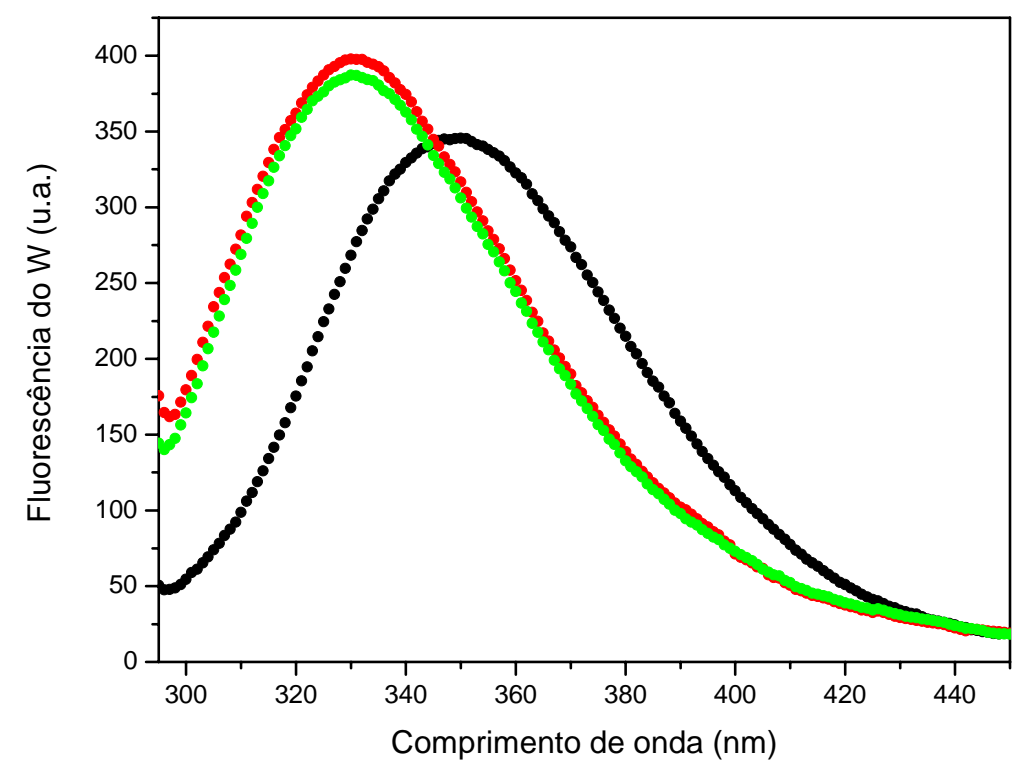

Figura 30 - Espectro de emissão de fluorescência do triptofano, presente no peptídeo híbrido linear, na presença de membranas compostas por 75:25 mol\% egg-PG:egg-PC. Em preto está o peptídeo híbrido livre em solução tampão. A curva vermelha foi obtida após a inserção de $30 \mu \mathrm{M}$ de vesículas na solução $e$ a solução e a verde após a inserção de $60 \mu \mathrm{M}$.

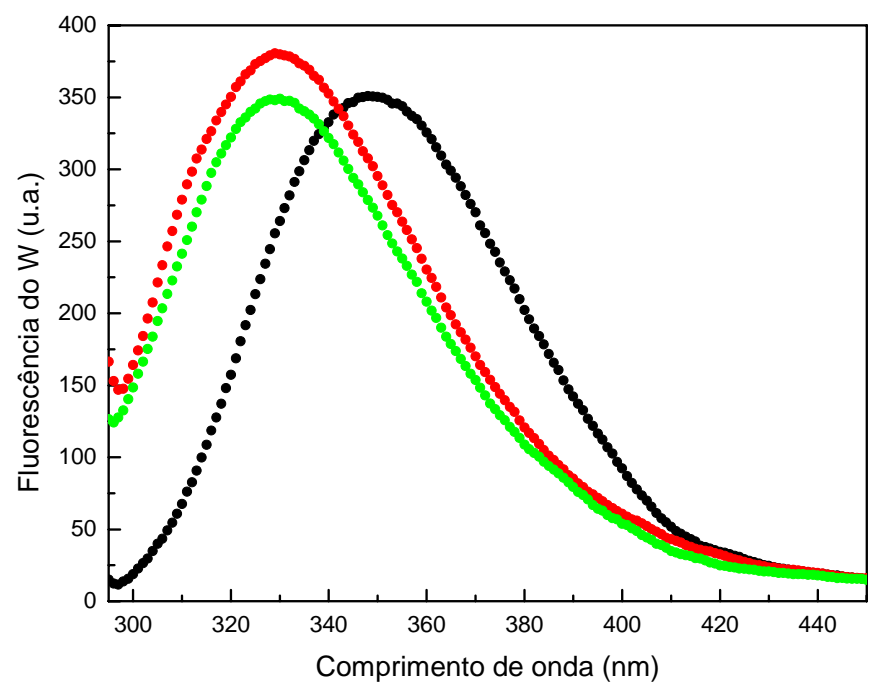

Figura 31 - Espectro de emissão de fluorescência do triptofano, presente no peptídeo híbrido linear, na presença de membranas compostas por egg-PG. Em preto está o peptídeo híbrido livre em solução tampão. A curva vermelha foi obtida após a inserção de $30 \mu \mathrm{M}$ de vesículas na solução e a solução e a verde após a inserção de $60 \mu \mathrm{M}$.

A tabela 3 apresenta o comprimento de onda do máximo de emissão de fluorescência do peptídeo híbrido livre em solução tampão, chamado de comprimento de onda inicial, o 
comprimento de onda final, referente ao menor comprimento de onda alcançado pelo máximo de emissão de fluorescência, cujos valores foram similares tanto para a adição de $1 \mu \mathrm{L}$ quanto de 2 $\mu \mathrm{L}$ de vesículas (veja figura 33 adiante).

\begin{tabular}{|c|c|c|c|}
\hline LUVs (mol\%) & $\lambda$ inicial (nm) & $\lambda$ final (nm) & Blue shift (nm) \\
\hline 100 PC & 348,0 & 342,0 & 6,0 \\
\hline 25 PG : 75 PC & 348,0 & 335,0 & 12,0 \\
\hline 50 PG : 50 PC & 348,0 & 333,0 & 15,0 \\
\hline 75 PG : 25 PC & 348,0 & 330,0 & 18,0 \\
\hline 100 PG & 348,0 & 328,0 & 20,0 \\
\hline
\end{tabular}

Tabela 3 - Tabela que relaciona comprimento de onda inicial, final e o deslocamento para o azul (blue shift) do pico de fluorescência do peptídeo híbrido para as diferentes membranas lipídicas.

A figura 32 apresenta um gráfico que relaciona o blue shift do máximo de emissão da fluorescência em relação à concentração de carga negativa $(\mathrm{PG})$ na superfície das membranas lipídicas utilizadas para esses experimentos. 


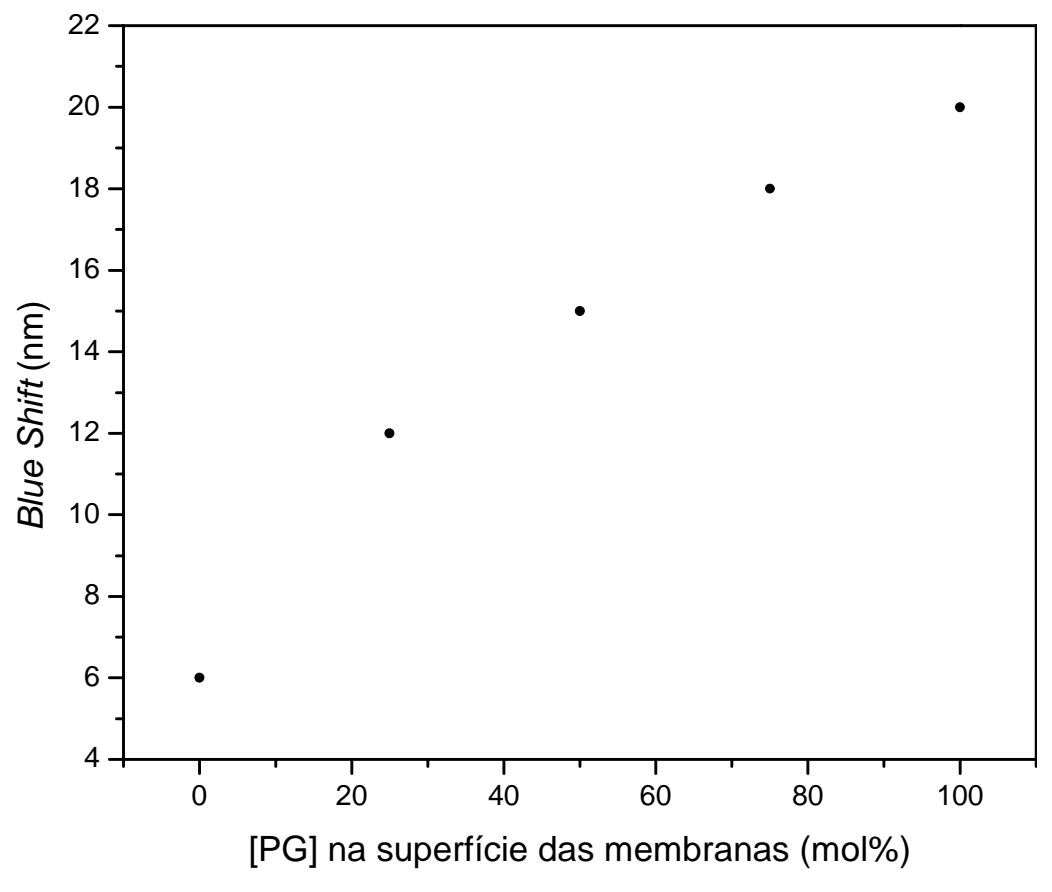

Figura 32 - Deslocamento para o azul (blue shift) do pico de fluorescência do triptofano monitorado na presença de diferentes membranas lipídicas. $O$ eixo x representa as diferentes concentrações de PG nas membranas lipídicas.

A figura 33 apresenta um gráfico que relaciona o blue shift do máximo de emissão da fluorescência em função da razão lipídeo/peptídeo, onde a primeira adição de vesículas corresponde a uma razão de 30 e a segunda adição da alíquota de vesículas é representada pela razão de 60. Os pontos pretos representam membranas de egg-PG, os vermelhos representam membranas compostas por 75:25 egg-PG:egg-PC (mol\%), os verdes representam as membranas compostas por 50:50 egg-PG:egg-PC (mol\%), os pontos azuis representam membranas compostas por 25:75 egg-PG:egg-PC (mol\%) e os pontos em ciano representam membranas compostas apenas por egg-PC. 


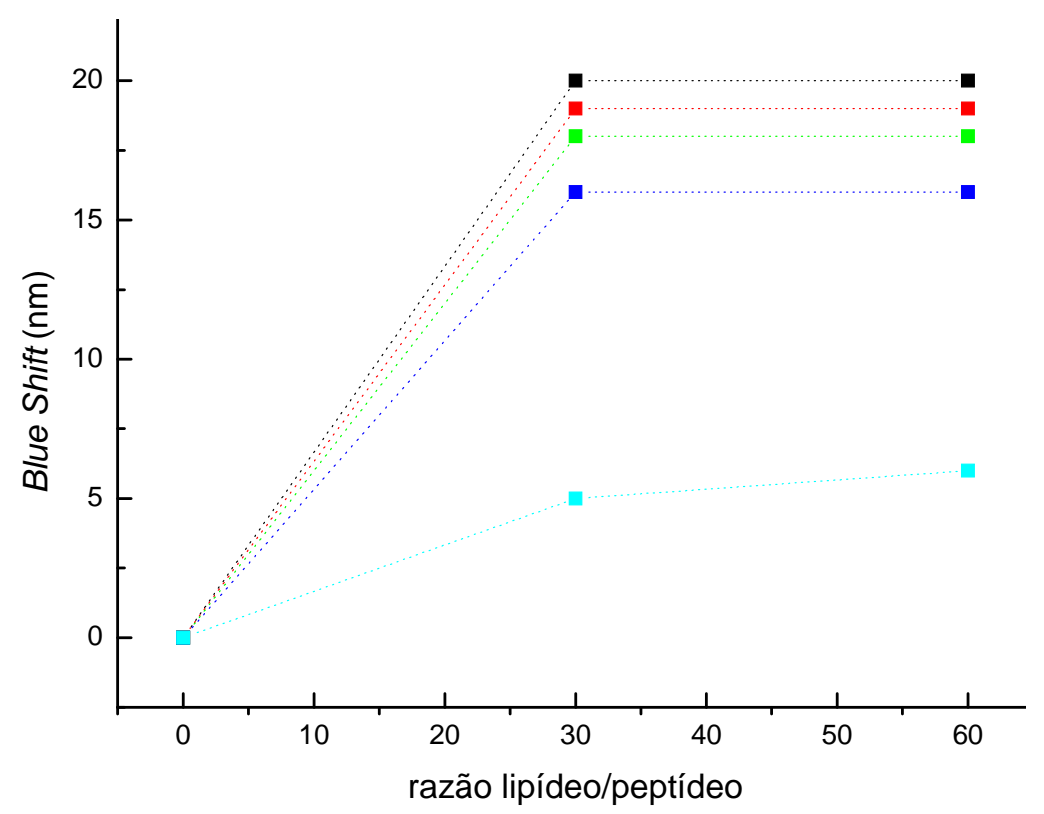

Figura 33 - Blue shift do pico de fluorescência do triptofano em função da razão lipídeo/peptídeo. Os pontos pretos representam membranas compostas por egg-PG, os vermelhos representam membranas compostas com 75 mol\% de egg-PG e 25 mol\% de egg-PC, os pontos verdes representam membranas constituídas por 50:50 mol\% de egg-PG:egg-PC, os pontos azuis representam membranas compostas por 25:75 mol\% de egg-PG:egg-PC e os pontos em ciano representam membranas compostas exclusivamente por egg-PC. As linhas pontilhadas representam guias de olho.

Portanto, os resultados de fluorescência de triptofano do peptídeo híbrido linear, apresentados nessa seção, mostram que quando o peptídeo está na solução tampão, ele apresenta um máximo de emissão de fluorescência em $348 \mathrm{~nm}$, um valor próximo de $353 \mathrm{~nm}$, que é o valor esperado para triptofano livre em água [38]. Foi também observado que quando esse peptídeo interage com membranas lipídicas o máximo de emissão de fluorescência sofre um deslocamento para comprimentos de onda menores, o chamado deslocamento para o azul ou blue shift, e um aumento da intensidade de fluorescência, quando vesículas contendo PG são adicionadas à solução de peptídeo.

O deslocamento para o azul comprova a mudança de meio em que o triptofano se encontra, passando de um meio polar, com uma constante dielétrica alta (solução tampão) para um de menor polaridade ( $\varepsilon$ menor). Isto nos indica que o peptídeo está interagindo com a membrana, uma vez que as cadeias hidrocarbônicas têm polaridade cerca de 10 vezes menor que a água [38]. Os diferentes deslocamentos para o azul apresentados como resultado da interação do peptídeo com as diferentes membranas, expostos na tabela 3 e também no gráfico da figura 
32, sugerem que existe uma preferência por parte desse peptídeo por interagir com membranas que possuem maior quantidade de carga negativa em sua superfície. O blue shift de apenas 6,0(7) $\mathrm{nm}$, ocorrido devido à interação do peptídeo com membranas de egg-PC, sugere que o resíduo de triptofano não está tão profundamente ancorado na região hidrofóbica dessas membranas. Já os valores de blue shift devido à interação entre o peptídeo e membranas que possuem lipídeos carregados são bem maiores, chegando até a 20,0(7) nm. Esse fato indica que o triptofano deve estar ancorado em uma região muito hidrofóbica dessa membrana, possivelmente perto das cadeias acilas dos lipídeos.

$\mathrm{O}$ aumento de intensidade de fluorescência é um indício de que o peptídeo tomou uma forma menos flexível. Quando o triptofano está em um meio onde ele possui grande mobilidade (solução tampão), ou seja, consegue vibrar, rotacionar, etc., parte da energia recebida para excitálo pode ser perdida nesses processos, antes de ele decair para o estado fundamental e emitir um fóton. Porém, quando ele está em um meio com uma organização maior (ancorado em uma membrana, por exemplo), isso diminui sua mobilidade e a perda por energia por vibração é menor, o que reflete em um aumento de intensidade de fluorescência.

Com base nesses resultados, nos de CD (lembrando que a razão lipídeo/peptídeo é de 40) e com a predição da estrutura secundária do peptídeo híbrido (figura 7), podemos fazer algumas considerações. A primeira delas é que, quando o peptídeo interage com membranas compostas unicamente por egg-PC, ele apresenta estrutura secundária desordenada e um blue shift de apenas 6,0(7) $\mathrm{nm}$. Isso sugere que o peptídeo carregado positivamente esteja interagindo apenas com a superfície da bicamada lipídica, uma vez que o triptofano não deve estar muito inserido nas vesículas e o peptídeo ainda se apresenta na forma desordenada. Com o aumento da quantidade de carga negativa na superfície da bicamada lipídica dois fenômenos ocorrem ao mesmo tempo: o peptídeo carregado positivamente interage mais fortemente com a membrana, havendo indução gradativa para uma conformação tipo helicoidal do peptídeo, acompanhado por um blue shift também gradativo nos espectros de fluorescência. Isso sugere que, possivelmente, os aminoácidos da região entre os resíduos 16 e 32 formem $\alpha$ - hélice, assim como é sugerido com a predição da estrutura secundária do peptídeo híbrido exposta na figura 7. Como o blue shift do peptídeo é maior, quanto maior for a quantidade de PG na superfície das membranas, pode-se também sugerir que a região helicoidal, contendo o triptofano, esteja cada vez mais inserida na bicamada lipídica. 
Portanto, nossos resultados sugerem que a conformação helicoidal adotada pelo peptídeo (resíduos 16 a 32) e sua inserção na membrana, como influência da quantidade de carga negativa da mesma, devem ser o primeiro passo para o mecanismo de ação desse peptídeo. Como veremos a seguir, o peptídeo induz, de fato, poros na membrana. Fazendo um paralelo com a seqüência da plantaricina 149a (figura 4 - resíduos 7 a 20) da hélice anfipática, as lisinas (K) devem preferir ficar expostas para regiões hidrofílicas, enquanto que os outros aminoácidos devem preferir ficar expostos ao meio hidrofóbico.

Nesse experimento não foi realizada a dosagem de fosfato para obter o valor exato da concentração de lipídeo em cada experimento. Porém, se admitirmos que todo o lipídeo utilizado na formação do filme lipídico no fundo do tubo de ensaio é mantido constante até o final da extrusão, ou seja, que não ocorra perda de lipídeo durante o processo de preparação de LUVs, é possível fazer algumas estimativas. Nesse caso, estima-se que a concentração final de lipídeos em cada adição de membranas é de $30 \mu \mathrm{M}$. Como a concentração de peptídeo é de $1 \mu \mathrm{M}$ em todas as experiências, temos que a relação peptídeo/lipídeo após a adição de $1 \mu \mathrm{L}$ de vesículas é de $1 / 30$ $(\sim 0,03)$ e após a segunda adição de vesículas é de 1/60 ( 0,017). Esses valores são muito próximos ou iguais aos valores obtidos no item a seguir, onde a dosagem de fosfato foi realizada e a razão peptídeo/lipídeo e sua relação com o rompimento de membranas foram discutidas. Isso significa que a quantidade de peptídeo utilizada nessas experiências é capaz de romper (totalmente ou parcialmente) as membranas lipídicas. Isso indica que todas as medidas foram realizadas com membranas lipídicas (compostas por egg-PC) e também com fragmentos de bicamada lipídica (mistas com egg-PG).

\subsection{Cinética de vazamento da CF}

A cinética de vazamento da carboxifluoresceína, encapsulada em diferentes vesículas compostas por egg-PC, egg-PG e colesterol, foi monitorada em função do tempo. As membranas utilizadas para essa experiência possuem a mesma composição lipídica que as utilizadas no item anterior, porém membranas constituídas de $57 \mathrm{~mol} \%$ de egg-PC e $43 \mathrm{~mol} \%$ de colesterol também foram fabricadas para essa experiência. Elas foram produzidas em tampão Tris-HCL, $10 \mathrm{mM}, \mathrm{pH}$ 7,4 e $300 \mathrm{mM}$ de $\mathrm{NaCl}$. O NaCl além de mimetizar o meio fisiológico, que contém cerca de 150 $\mathrm{mM}$ de sal, é também necessário para manter o balanço de força iônica [29]. 
O primeiro passo da experiência foi monitorar a fluorescência da carboxifluoresceína que ocorre devido ao vazamento espontâneo das membranas. Uma alíquota de $2,5 \mu \mathrm{L}$ de vesículas foi adicionada $0,5 \mathrm{~mL}$ da solução tampão. A concentração de lipídeos nessa experiência é difícil de ser estimada, pois o processo de retirada da carboxifluoresceína não encapsulada nas LUVs requer uma diluição da solução de vesículas e nem toda a solução é aproveitada no final. Por isso, nessa experiência, foi realizada a dosagem de fosfato, para que a concentração de lipídeos e a relação lipídeo/peptídeo sejam bem determinadas.

$\mathrm{O}$ segundo passo da experiência foi acompanhar o vazamento da CF encapsulada nas LUVs devido à adição de peptídeo na solução contendo membranas lipídicas. Para isso, diferentes quantidades do peptídeo foram adicionadas, apenas uma vez por experiência, na solução que contém $500 \mu \mathrm{L}$ de tampão e $2,5 \mu \mathrm{L}$ de vesículas. Esse vazamento foi acompanhado por cerca de $1750 \mathrm{~s}$. Após tal período, todas as vesículas foram rompidas com $10 \mu \mathrm{L}$ de uma solução de polidocanol em água MiliQ (10\% peso/peso), para que o máximo de fluorescência da CF fosse observada.

Todas as curvas de cinética de vazamento da CF estão apresentadas abaixo. Elas foram normalizadas utilizando a equação 3, e considerando o valor máximo de fluorescência da $\mathrm{CF}$, após a adição do polidocanol, como sendo $100 \%$ de vazamento. 


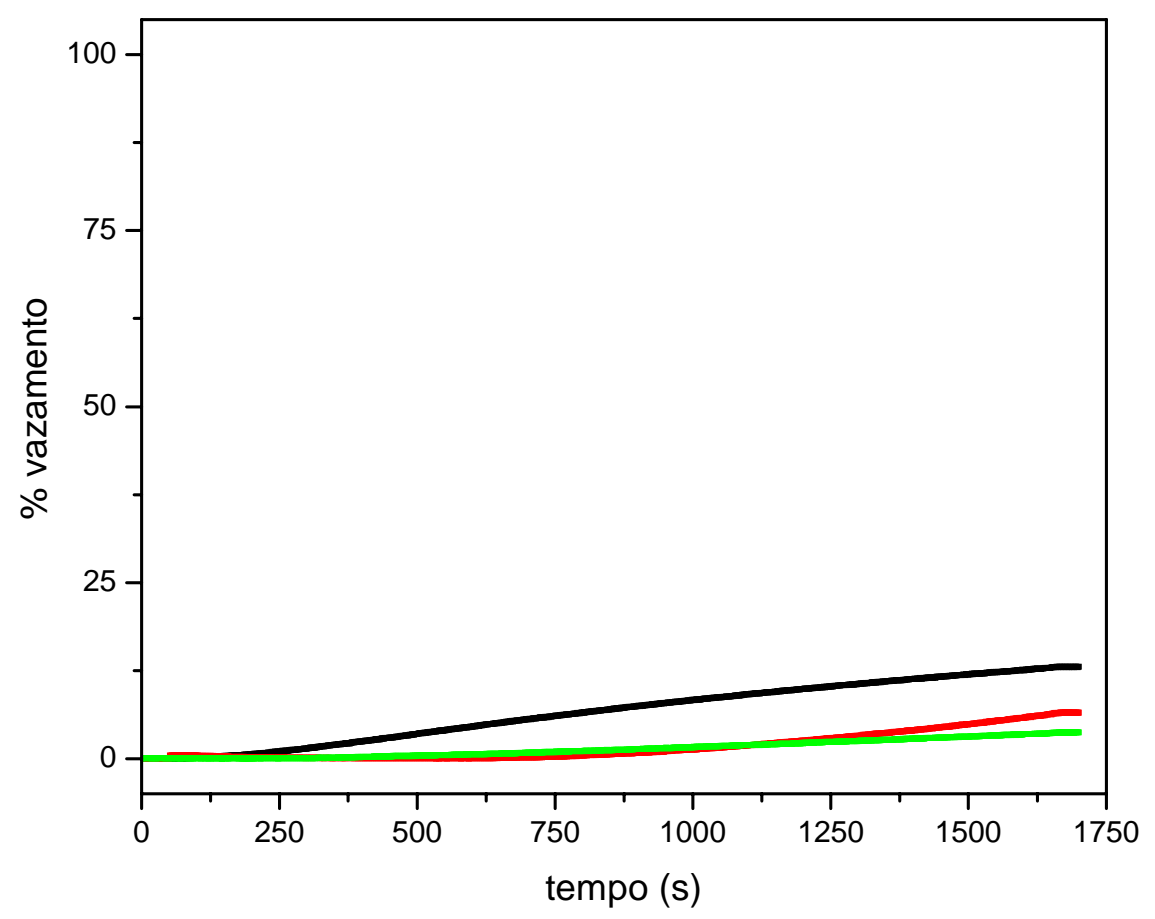

Figura 34 - Cinética de vazamento da CF para o peptídeo híbrido e membranas de 57:43 eggPC:colesterol (mol\%). $(-)$ lipossomo controle, $(-) 1 \mu \mathrm{Me}(-) 2 \mu \mathrm{M}$.

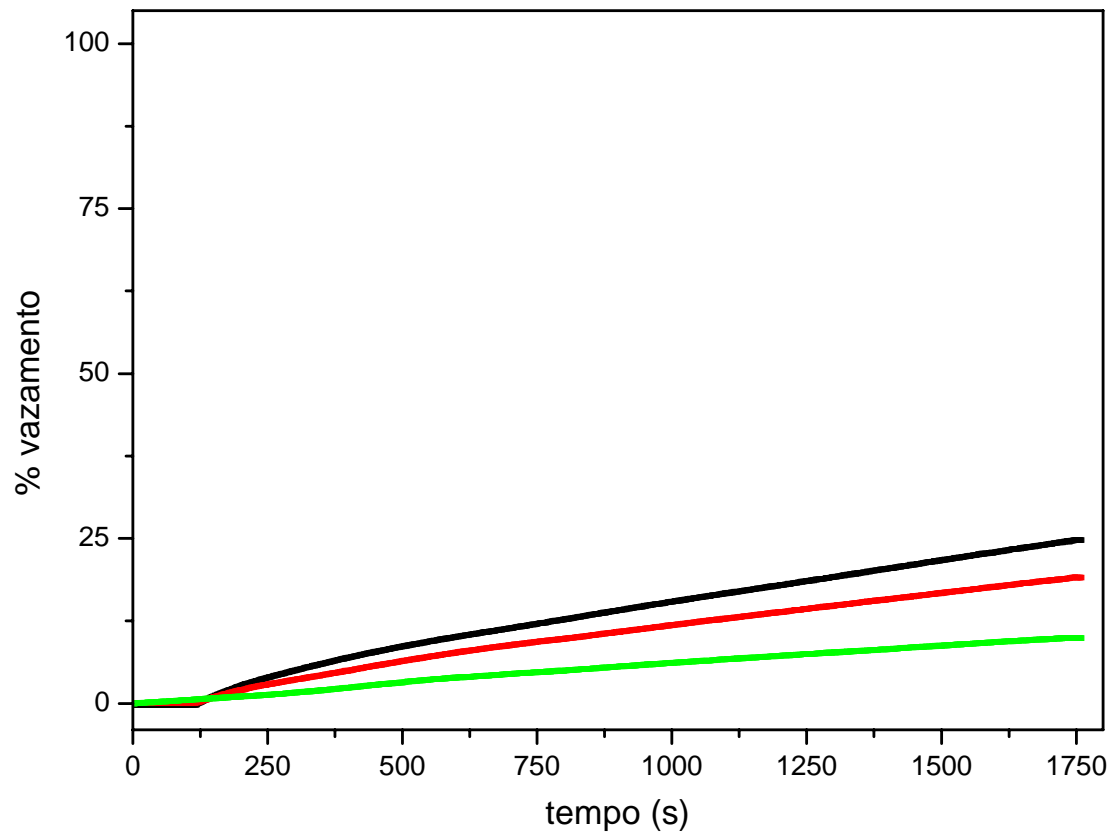

Figura 35 - Cinética de vazamento da CF para o peptídeo híbrido e membranas de 100 mol\% de egg-PC. (-) lipossomo controle, (-) 0,5 $\mu \mathrm{Me}$ (-) $1 \mu \mathrm{M}$ 


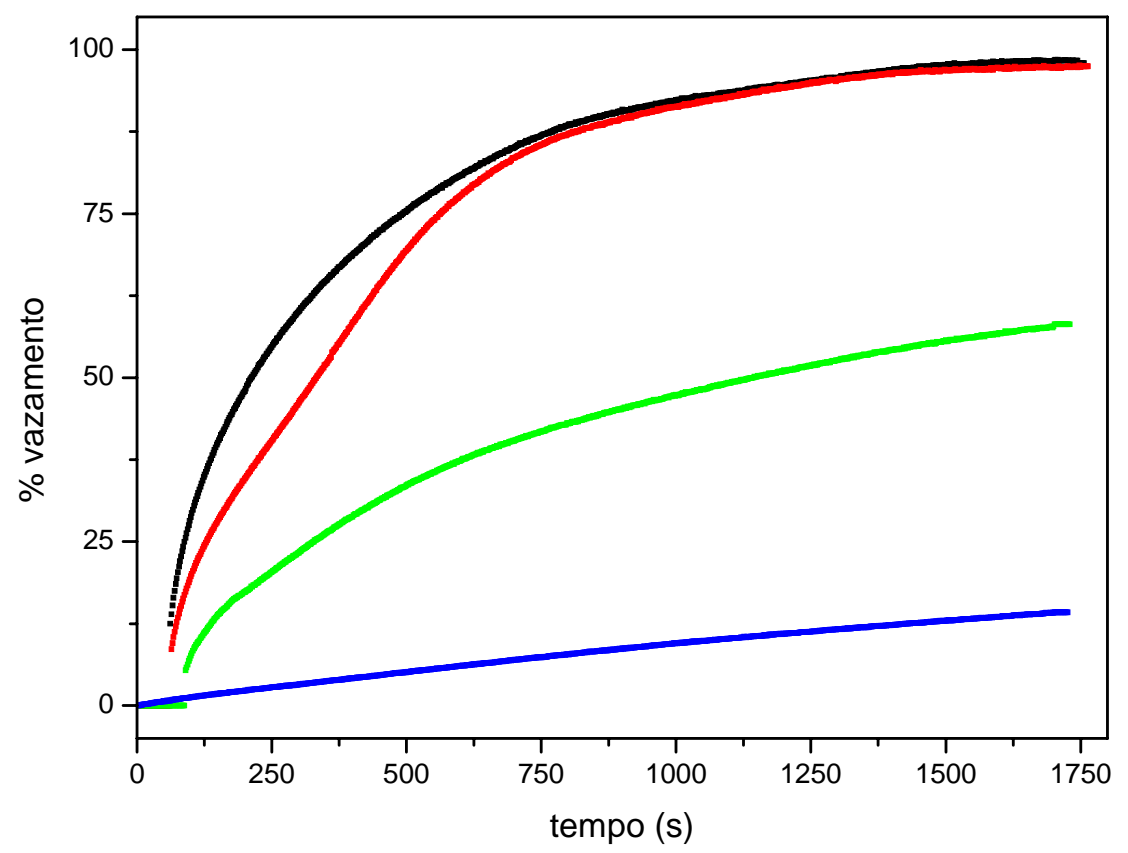

Figura 36 - Cinética de vazamento da CF para o peptídeo híbrido e membranas de 75:25 egg-PC:egg-PG (mol\%).(-) lipossomo controle, (-) 0,125 $\mu \mathrm{M}$, (一) 0,25 $\mu \mathrm{M}$ e (-) 0,5 $\mu \mathrm{M}$.

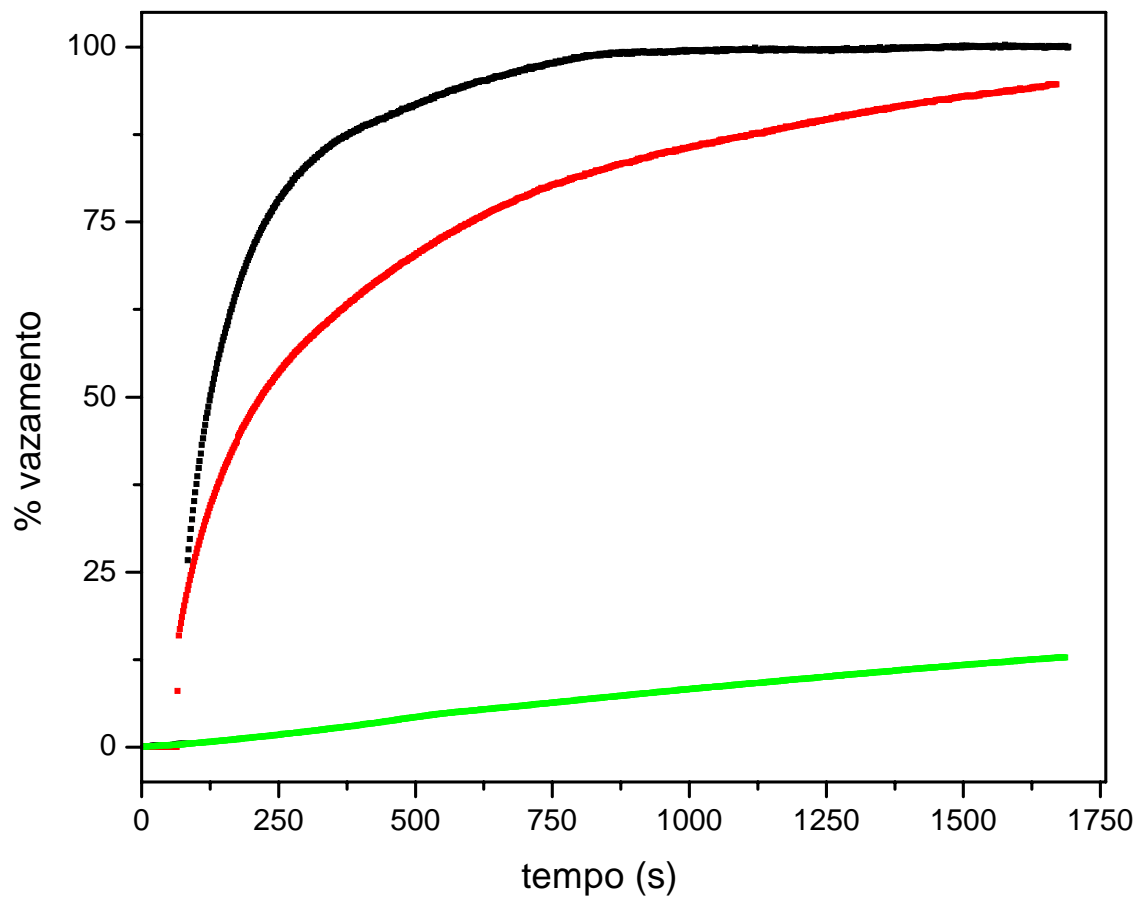

Figura 37 - Cinética de vazamento da CF para o peptídeo híbrido e membranas de 50:50 egg-PC:egg-PG (mol\%). (-) lipossomo controle, (-) 0,125 $\mu \mathrm{M}$ e (-) 0,25 $\mu \mathrm{M}$. 


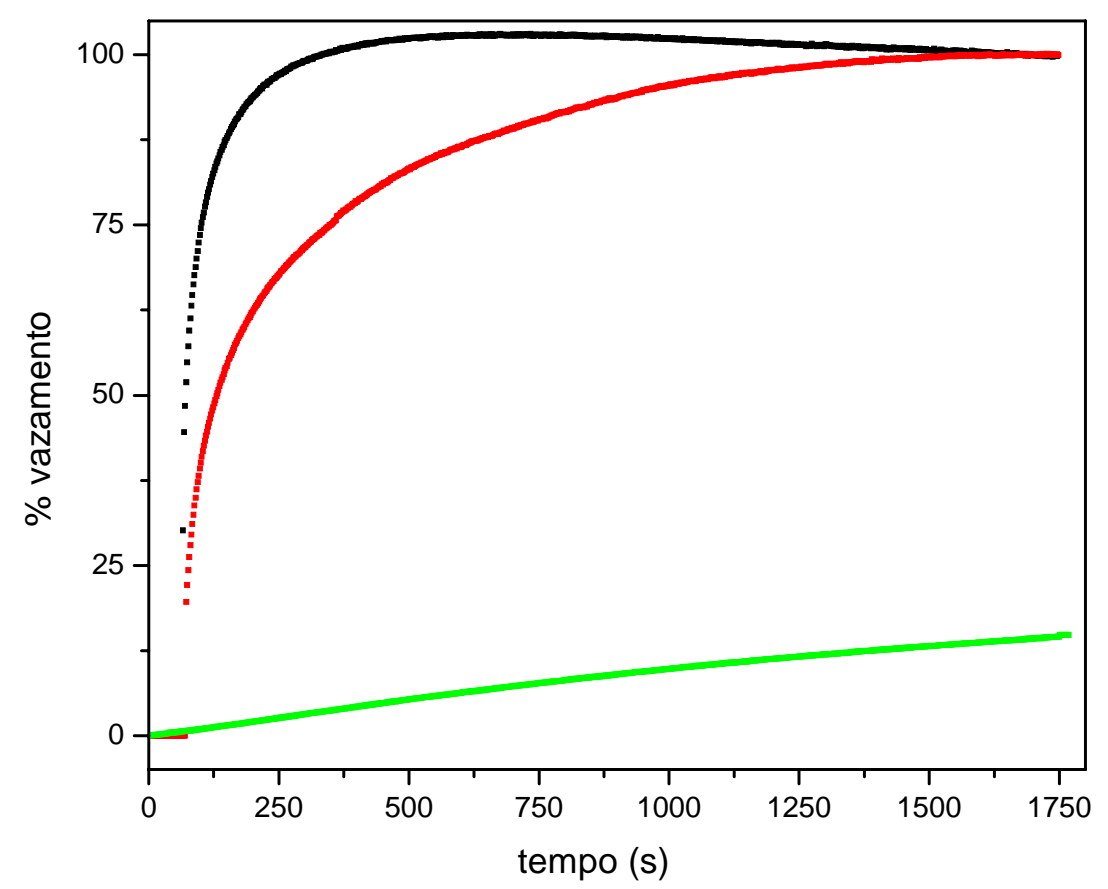

Figura 38 - Cinética de vazamento da CF para o peptídeo híbrido e membranas de 25:75 egg-PC:egg-PG (mol\%). ( ) lipossomo controle, (-) 0,125 $\mu \mathrm{Me}$ e (一) 0,25 $\mu \mathrm{M}$.

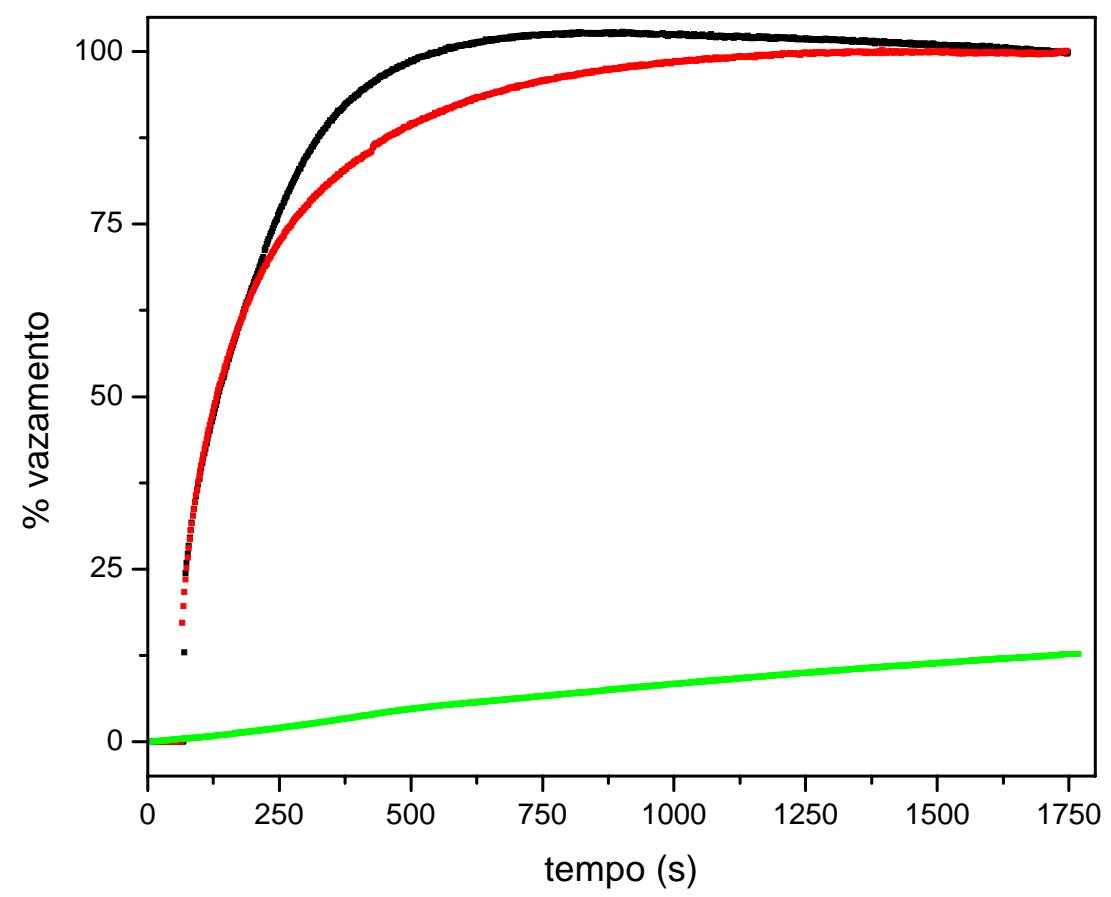

Figura 39 - Cinética de vazamento da CF para o peptídeo híbrido e membranas de 100 mol\% de egg-PG (mol\%). (-) lipossomo controle, (-) 0,060 $\mu \mathrm{Me}$ (-) 0,125 $\mu \mathrm{M}$. 
É comum, para a análise dos dados apresentados nas figura 34 a figura 39, ajustar uma curva exponencial para obter um tempo característico da cinética de vazamento. Porém esse procedimento não foi possível de ser adotado aqui, pois essa cinética é muito rápida e não conseguimos um bom ajuste para o conjunto de dados. Apenas para comparação, a relação \% de vazamento/s foi determinada para o início da cinética. Uma reta foi ajustada aos primeiros pontos experimentais de cada curva, com exceção das curvas de lipossomo controle, que todos os pontos foram utilizados para o ajuste. Os valores de velocidade do início da cinética estão apresentados na tabela 4.

\begin{tabular}{|c|c|c|}
\hline $\begin{array}{c}\text { Membranas } \\
(\mathrm{mol} \%)\end{array}$ & $\begin{array}{c}\text { [peptídeo híbrido] } \\
(\mu \mathrm{M})\end{array}$ & $\begin{array}{c}\text { Velocidade do início } \\
\text { da interação } \\
(\% \text { de vazamento/s })\end{array}$ \\
\hline 57 egg-PCl & 2,000 & 0,009 \\
43 colesterol & 1,000 & 0,004 \\
Controle & 0,002 \\
\hline & 1,000 & 0,014 \\
100 egg-PC & 0,500 & 0,011 \\
& Controle & 0,006 \\
\hline & 0,500 & 0,419 \\
75 egg-PCl & 0,250 & 0,299 \\
25 egg-PG & 0,125 & 0,134 \\
& Controle & 0,008 \\
\hline & 0,250 & 0,630 \\
50 egg-PCl & 0,125 & 0,344 \\
50 egg-PG & Controle & 0,008 \\
\hline & 0,250 & 1,748 \\
25 egg-PCl & 0,125 & 0,810 \\
75 egg-PG & Controle & 0,008 \\
\hline & 0,125 & 0,943 \\
100 egg-PG & 0,060 & 0,940 \\
& Controle & 0,007 \\
\hline
\end{tabular}

Tabela 4 - Velocidade do início da cinética de vazamento da CF para cada um dos experimentos. Esses valores foram obtidos através do ajuste de uma reta aos primeiros pontos da curva. 
A tabela 5 apresenta dados que relacionam tempo e porcentagem de vazamento. A coluna chamada de $t_{1 / 2}$ apresenta dados do tempo em que metade do vazamento total das membranas ocorreu e a coluna de \% de vazamento apresenta essa porcentagem no tempo de $1650 \mathrm{~s}$.

\begin{tabular}{|c|c|c|c|}
\hline $\begin{array}{l}\text { Membranas } \\
(\mathrm{mol} \%)\end{array}$ & $\begin{array}{c}\text { [peptídeo híbrido] } \\
(\mu \mathrm{M})\end{array}$ & $\mathrm{t}_{1 / 2}(\mathrm{~s})$ & $\begin{array}{l}\% \text { vazamento } \\
\mathrm{em} \mathrm{t}=1650 \mathrm{~s}\end{array}$ \\
\hline $\begin{array}{l}57 \text { egg-PC/ } \\
43 \text { colesterol }\end{array}$ & $\begin{array}{c}2,000 \\
1,000 \\
\text { Controle }\end{array}$ & $\begin{array}{l}- \\
- \\
-\end{array}$ & $\begin{array}{c}12,9 \\
6,3 \\
3,6\end{array}$ \\
\hline 100 egg-PC & $\begin{array}{c}1,000 \\
0,500 \\
\text { Controle }\end{array}$ & $\begin{array}{l}- \\
- \\
-\end{array}$ & $\begin{array}{c}23,6 \\
18,2 \\
9,5\end{array}$ \\
\hline $\begin{array}{l}75 \text { egg-PC/ } \\
25 \text { egg-PG }\end{array}$ & $\begin{array}{c}0,500 \\
0,250 \\
0,125 \\
\text { Controle }\end{array}$ & $\begin{array}{c}212 \\
334 \\
1148 \\
-\end{array}$ & $\begin{array}{l}98,3 \\
97,2 \\
57,4 \\
13,9\end{array}$ \\
\hline $\begin{array}{l}50 \text { egg-PC/ } \\
50 \text { egg-PG }\end{array}$ & $\begin{array}{c}0,250 \\
0,125 \\
\text { Controle }\end{array}$ & $\begin{array}{c}126 \\
218 \\
-\end{array}$ & $\begin{array}{l}99,9 \\
94,9 \\
12,6\end{array}$ \\
\hline $\begin{array}{l}25 \text { egg-PC/ } \\
75 \text { egg-PG }\end{array}$ & $\begin{array}{c}0,250 \\
0,125 \\
\text { Controle }\end{array}$ & $\begin{array}{c}72 \\
132 \\
-\end{array}$ & $\begin{array}{l}100 \\
99,9 \\
13,8\end{array}$ \\
\hline 100 egg-PG & $\begin{array}{c}0,125 \\
0,060 \\
\text { Controle }\end{array}$ & $\begin{array}{c}134 \\
132 \\
-\end{array}$ & $\begin{array}{l}100 \\
99,8 \\
12,1\end{array}$ \\
\hline
\end{tabular}

Tabela 5 - Relação entre tempos e porcentagens de vazamentos. A coluna $t_{1 / 2}$ apresenta o tempo em que metade do vazamento total de CF ocorreu e a coluna de \% de vazamento apresenta dados dos vazamentos de CF em um tempo definido de $1650 \mathrm{~s}$.

Como cada lipídeo utilizado possui um fósforo em sua cabeça polar, é possível determinar a concentração de lipídeos que foi utilizada em cada um dos experimentos, através da dosagem de fosfato orgânico (seção 2.2.5.2). A tabela 6 apresenta a concentração de fosfato presente em 2,5 $\mu \mathrm{L}$ de vesículas em um volume final de $500 \mu \mathrm{L}$ de solução tampão para cada tipo de membrana utilizada. 


\begin{tabular}{|c|c|}
\hline $\begin{array}{c}\text { Membranas } \\
(\text { mol } \%)\end{array}$ & $\begin{array}{c}\text { [fosfato] de 2,5 } \mu 1 \text { de vesículas } \\
\text { em } 500 \mu \text { de solução tampão } \\
(\mu \mathrm{M})\end{array}$ \\
\hline 57 egg-PC/43 colesterol & 5,9 \\
\hline 100 egg-PC & 7,3 \\
\hline 75 egg-PC:25 egg-PG & 14,3 \\
\hline 50 egg-PC:50 egg-PG & 23,9 \\
\hline 25 egg-PC:75 egg-PG & 18,5 \\
\hline 100 egg-PG & 14,7 \\
\hline
\end{tabular}

Tabela 6 - Concentração de fosfato presente em 2,5 $\mu$ de vesículas em um volume final de $500 \mu \mathrm{l}$ de solução tampão, utilizado para as medidas de cinética de vazamento de CF.

Uma importante relação é a razão peptídeo/lipídeo em cada experimento realizado. Através dela é possível estimar quantos peptídeos por lipídeos foram necessários para que determinado fenômeno ocorresse. Para obter essa relação basta calcular a razão entre a concentração de peptídeo e a concentração de fosfato das vesículas (tabela 6). A tabela 7 apresenta essa relação peptídeo/lipídeo para cada umas das medidas realizadas. 


\begin{tabular}{|c|c|c|c|c|c|}
\hline $\begin{array}{c}\text { Membranas } \\
(\mathrm{mol} \%)\end{array}$ & $\begin{array}{c}\text { [peptídeo] } \\
(\mu \mathrm{M})\end{array}$ & $\begin{array}{l}\text { Razão } \\
\text { pep/lip }\end{array}$ & $\begin{array}{c}\text { Membranas } \\
(\mathrm{mol} \%)\end{array}$ & $\begin{array}{c}\text { [peptídeo] } \\
(\mu \mathrm{M})\end{array}$ & $\begin{array}{l}\text { Razão } \\
\text { pep/lip }\end{array}$ \\
\hline $\begin{array}{c}57 \text { egg-PC/ } \\
43 \text { colesterol }\end{array}$ & $\begin{array}{c}2,000 \\
1,000 \\
\text { Controle }\end{array}$ & $\begin{array}{c}0,341 \\
0,171 \\
0\end{array}$ & $\begin{array}{l}50 \text { egg-PC/ } \\
50 \text { egg-PG }\end{array}$ & $\begin{array}{c}0,250 \\
0,125 \\
\text { Controle }\end{array}$ & $\begin{array}{c}0,010 \\
0,005 \\
0\end{array}$ \\
\hline 100 egg-PC & $\begin{array}{c}1,000 \\
0,500 \\
\text { Controle }\end{array}$ & $\begin{array}{c}0,137 \\
0,068 \\
0\end{array}$ & $\begin{array}{l}25 \text { egg-PC/ } \\
75 \text { egg-PG }\end{array}$ & $\begin{array}{c}0,250 \\
0,125 \\
\text { Controle }\end{array}$ & $\begin{array}{c}0,014 \\
0,007 \\
0\end{array}$ \\
\hline $\begin{array}{l}75 \text { egg-PC/ } \\
25 \text { egg-PG }\end{array}$ & $\begin{array}{c}0,500 \\
0,250 \\
0,125 \\
\text { Controle }\end{array}$ & $\begin{array}{c}0,035 \\
0,017 \\
0,009 \\
0\end{array}$ & 100 egg-PG & $\begin{array}{c}0,125 \\
0,060 \\
\text { Controle }\end{array}$ & $\begin{array}{c}0,009 \\
0,004 \\
0\end{array}$ \\
\hline
\end{tabular}

Tabela 7 - Razão peptídeo/lipídeo para cada uma das experiências realizadas. Essa relação foi obtida através da divisão da concentração de peptídeo pela concentração de fosfato das membranas (dados apresentados na tabela 6).

Através das curvas de cinética de vazamento de CF também é possível obter informações sobre dose-resposta do peptídeo em relação à quantidade de peptídeo e membranas utilizada. Para isso, a figura 40 apresenta um gráfico que relaciona a porcentagem de vazamento de CF em função da razão peptídeo/lipídeo em um tempo fixo de 150 segundos. Para a análise temporal desses dados outros tempos foram escolhidos: 300, 600, 1200 e 1650 s, pois assim, o início, o fim e três pontos intermediários da cinética foram analisados. Esses gráficos estão apresentados abaixo. 


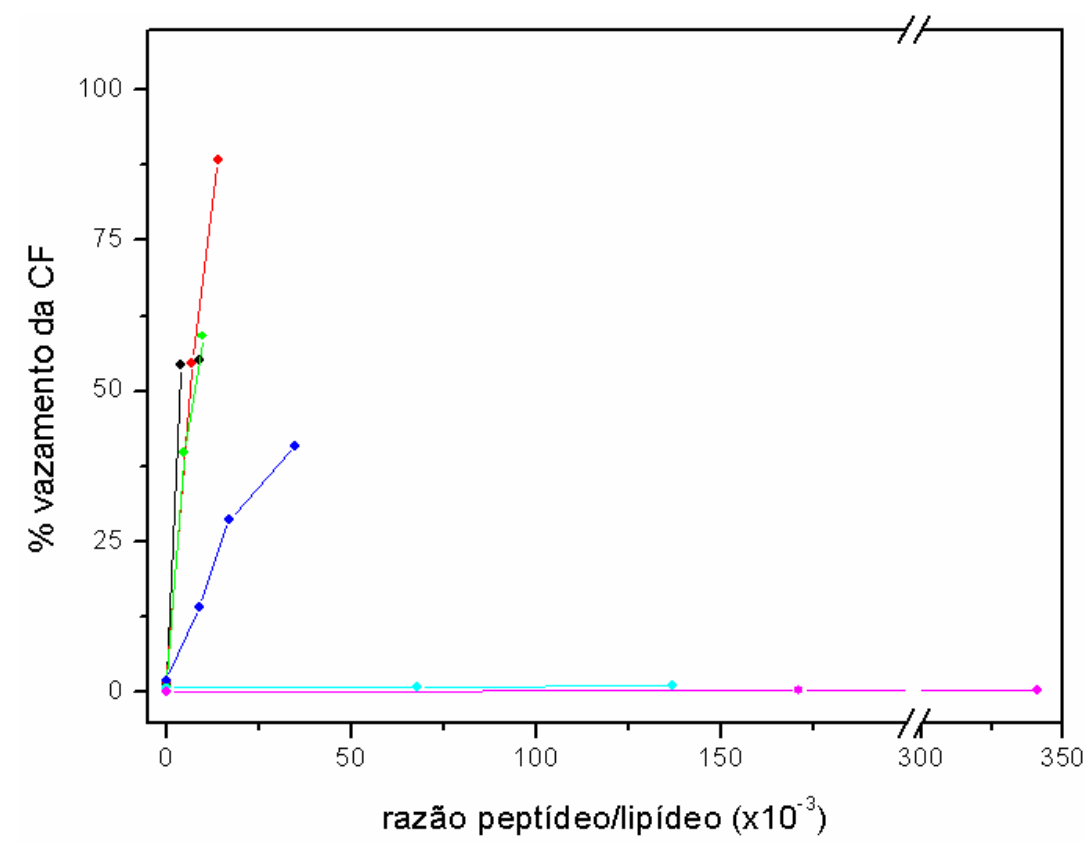

Figura 40 - Dose - resposta para o peptídeo híbrido após 150 segundos de interação com as membranas. As concentrações de lipídeos nas membranas estão apresentadas em mol\%. \%.(•) 57:43 egg-

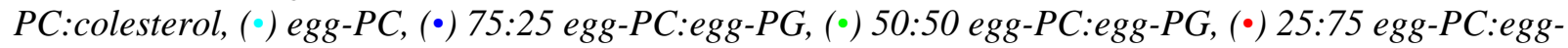
$P G$ e $(\bullet)$ egg-PG.

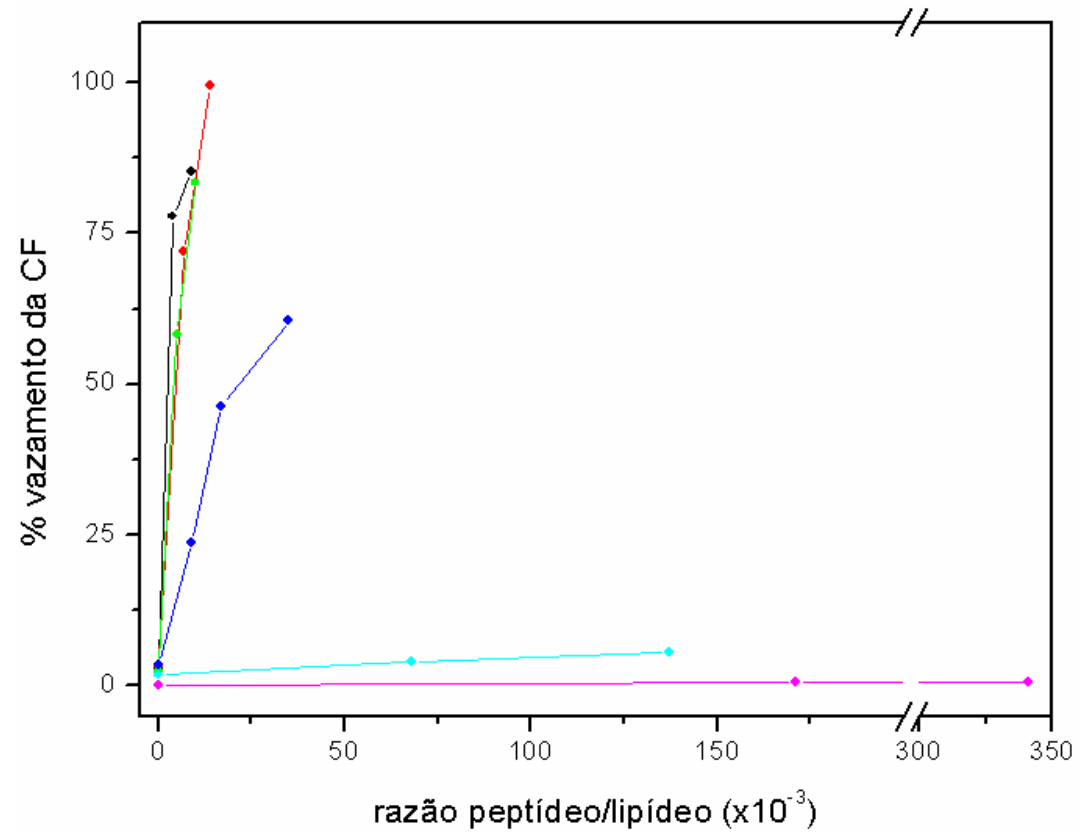

Figura 41 - Dose - resposta para o peptídeo híbrido após 300 segundos de interação com as membranas. As concentrações de lipídeos nas membranas estão apresentadas em mol\%. \%.(•) 57:43 egg-

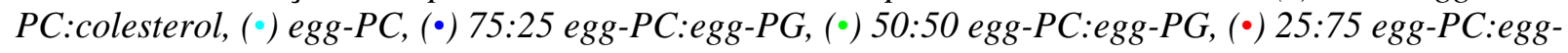
$P G$ e $(\bullet)$ egg-PG. 


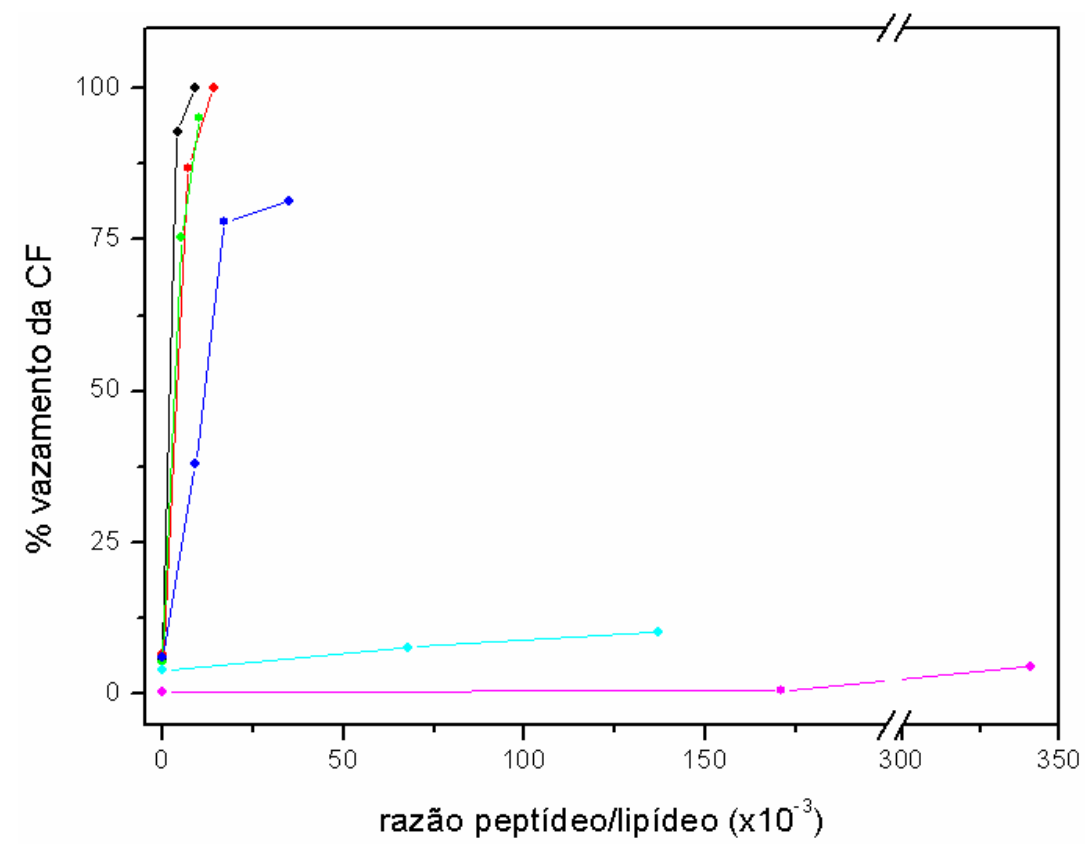

Figura 42 - Dose - resposta para o peptídeo híbrido após 600 segundos de interação com as membranas. As concentrações de lipídeos nas membranas estão apresentadas em mol\%.(•) 57:43 egg-PC:colesterol,

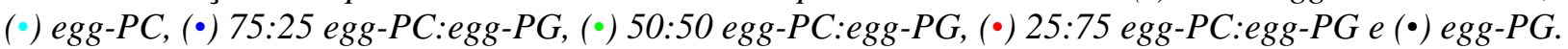

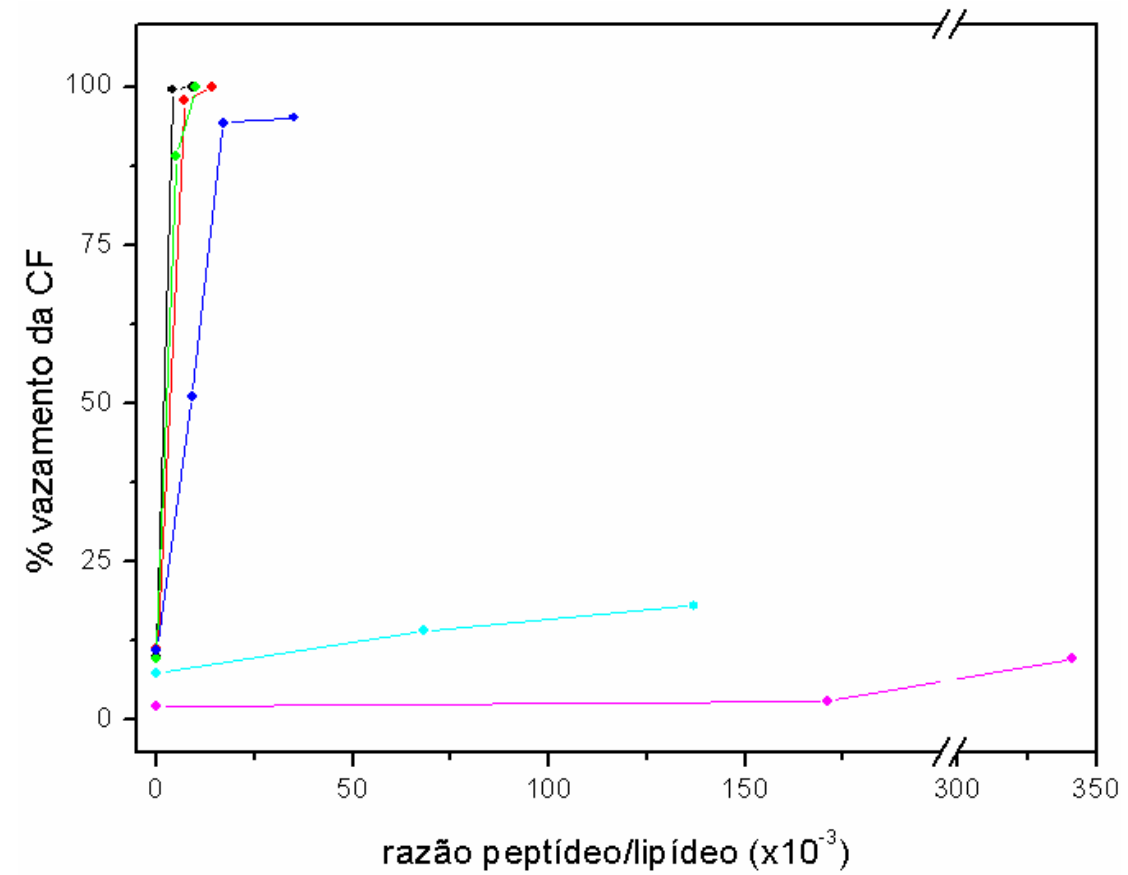

Figura 43 - Dose - resposta para o peptídeo híbrido após 1200 segundos de interação com as membranas. As concentrações de lipídeos nas membranas estão apresentadas em mol\%.(•) 57:43 egg-

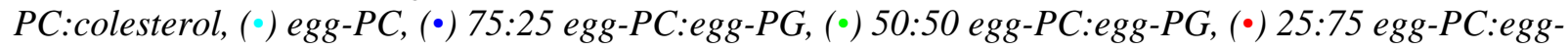
$P G$ e $(\bullet)$ egg-PG. 


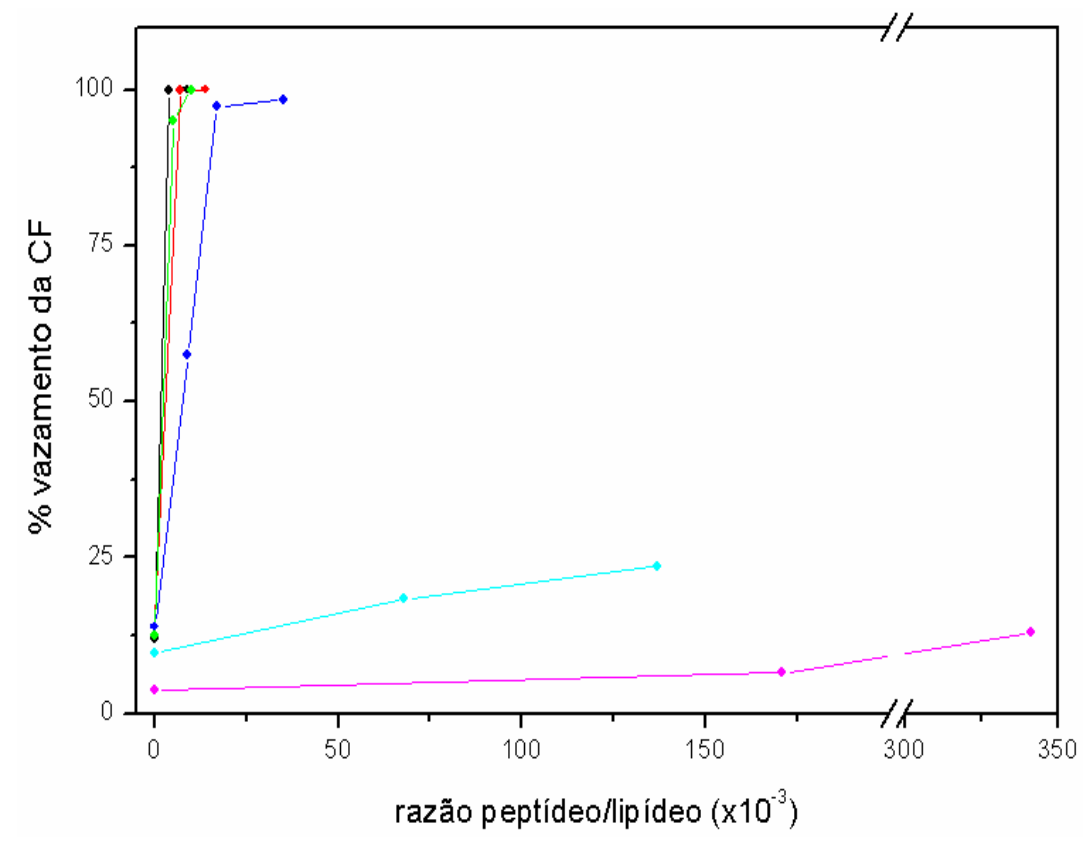

Figura 44 - Dose - resposta para o peptídeo híbrido após 1650 segundos de interação com as membranas. As concentrações de lipídeos nas membranas estão apresentadas em mol\%.(•) 57:43 egg-

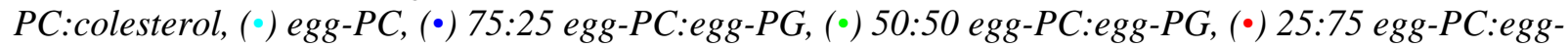
$P G$ e $(\bullet)$ egg-PG.

Através das medidas de cinética de vazamento da CF e da dosagem de fosfato das membranas lipídicas foi possível obter um grande número de dados. Eles, inicialmente, serão discutidos separadamente, seguindo a ordem dos seguintes tópicos: curvas de cinética de vazamento da $\mathrm{CF}$ e velocidade inicial da interação, porcentagem de vazamento e $t_{1 / 2}$, dosagem de fosfato das membranas, razão peptídeo/lipídeo e gráficos de dose-resposta.

As curvas de cinética de vazamento de CF, apresentadas da figura 34 a figura 39, mostram a porcentagem de vazamento de carboxifluoresceína das LUVs, em função do tempo. A partir dessas curvas pode-se afirmar que a cinética de vazamento de CF é completamente diferente entre as membranas que possuem egg-PG e as que não possuem. Esse resultado está de acordo com o resultado obtido na seção 3.2, onde mostra que o peptídeo tem preferência por interagir com membranas que possuem cargas negativas em sua superfície. Outro fato é que as membranas compostas por $43 \mathrm{~mol} \%$ de colesterol e $57 \mathrm{~mol} \%$ de egg-PC apresentaram sistematicamente um vazamento inferior às membranas compostas apenas por egg-PC, inclusive no vazamento espontâneo de CF das LUVs, representados pela curva de lipossomo controle em 
cada figura. Esse resultado evidencia o fato, já conhecido na literatura, de que o colesterol pode organizar as cadeias de carbono dos fosfolipídeos, enrijecendo a bicamada lipídica [45].

Como já discutido anteriormente nessa seção, nenhuma curva foi ajustada a esses pontos experimentais, pois a cinética de vazamento de CF é muito rápida. Porém, apenas para uma simples comparação, uma reta foi ajustada aos primeiros pontos dos gráficos (figura 34 a figura 39), onde as curvas ainda apresentavam uma certa linearidade. O valor do coeficiente angular dessas retas nos fornece a variação da porcentagem de vazamento de CF em função do tempo, do início da interação. Os dados obtidos através desse procedimento estão na tabela 4. Esses resultados mostram que a variação inicial de interação entre o peptídeo e as LUVs que não contém egg-PG em sua superfície é, da ordem de, cem vezes menor que a variação inicial da interação entre o peptídeo e membranas carregadas negativamente. Esses resultados evidenciam a seletividade do peptídeo, mostrando que ele tem preferência por interagir com membranas contendo carga negativa na superfície da bicamada lipídica e que essa carga é necessária para que o peptídeo atue na membrana, produzindo poros.

A tabela 5 apresenta a porcentagem de vazamento de CF em $1650 \mathrm{~s}$ e o tempo em que metade do vazamento de $\mathrm{CF}$ ocorreu, chamado de $\mathrm{t}_{1 / 2}$. Para membranas contendo egg-PC o vazamento de CF não atingiu os 50\% no tempo da experiência e, portanto, não foi possível a determinação de $\mathrm{t}_{1 / 2}$. Porém, para membranas que contém mais de $50 \mathrm{~mol} \%$ de egg-PG, esse tempo é da ordem de $100 \mathrm{~s}$. Esse resultado novamente evidencia que a cinética de vazamento de CF é muito rápida, pois em menos de 2 minutos, mais de $50 \%$ de vazamento de $\mathrm{CF}$ foi observado para membranas compostas também por egg-PG. Quanto a porcentagem de vazamento de CF em $1650 \mathrm{~s}$ (tempo escolhido por ser muito próximo ao tempo da adição de polidodecanol), pode-se notar que apenas membranas contendo egg-PG em sua superfície atingiram uma porcentagem de vazamento muito próxima ou igual a 100\%. Esse resultado sugere, novamente, que a presença de cargas negativas na superfície das membranas é fundamental para favorecer a interação entre o peptídeo híbrido e membranas lipídicas.

Um dado importante para a apresentação dos resultados é a relação peptídeo/lipídeo de cada interação. A quantidade de lipídeo utilizada em cada experimento só pode ser determinada pela dosagem de fosfato. Esse procedimento foi realizado como descrito na seção 2.2.5.2 e os resultados estão apresentados na tabela 6. Esses valores de concentração de fosfato são das quantidades de lipídeos utilizadas em cada experiência. A razão peptídeo/lipídeo foi obtida 
através da divisão da concentração de peptídeo pela concentração de fosfato e esses dados estão apresentados na tabela 7. Eles mostram que a razão peptídeo/lipídeo para formar poros em membranas compostas por egg-PC é, pelo menos, uma ordem de grandeza maior se comparada com a razão peptídeo/lipídeo para as membranas compostas por egg-PG. Mesmo com uma relação peptídeo/lipídeo muito menor nos experimentos com membranas contendo qualquer quantidade de egg-PG, o vazamento de CF observado foi muito maior, podendo chegar a $100 \%$ em alguns casos. Novamente, esses resultados evidenciam a importância da presença de cargas negativas na superfície de membranas para favorecer a interação entre o peptídeo e as membranas lipídicas.

Por fim, são apresentados gráficos de dose-resposta desse peptídeo. Tal gráfico relaciona, em um tempo fixo, a porcentagem de vazamento de $\mathrm{CF}$ em função da razão molar peptídeo/lipídeo. Esses dados foram comparados em quatro diferentes tempos, 150, 300, 600, 1200 e 1650 s, possibilitando a avaliação da evolução do vazamento da CF no tempo. Esses dados apresentam, para membranas compostas por colesterol e egg-PC, além de uma baixa porcentagem de vazamento de $\mathrm{CF}$, uma pequena variação desse vazamento em função do tempo. Para as membranas compostas unicamente por egg-PC esse vazamento é um pouco maior, chegando a um valor próximo de $25 \%$. A grande diferença é notada nos resultados obtidos com membranas que possuem egg-PG em sua composição. A porcentagem de vazamento, além de ser muito elevada (acima de 50\% para membranas com mais de $25 \mathrm{~mol} \%$ de egg-PG, em qualquer tempo avaliado), também atinge $100 \%$ de vazamento. Mais uma vez os resultados estão de acordo com o fato de que a carga na superfície da membrana é fundamental para a interação entre o peptídeo e as membranas e que o colesterol possui um papel importante, diminuindo consideravelmente a ação do peptídeo nas membranas, provavelmente devido ao seu poder de enrijecimento da bicamada lipídica. 


\section{Microscopia Óptica (MO) - Resultados e Discussão}

\subsection{Interação de Membranas Modelo (GUVs) com o Peptídeo Híbrido}

As medidas de microscopia óptica foram realizadas, a temperatura ambiente, com quatro membranas lipídicas diferentes. São elas: 100 mol\% POPC, 57:43 POPC:colesterol (mol\%), 20:80 POPC:POPG (mol\%) e 50:50 POPC:POPG (mol\%). Não foi possível crescer GUVs com maior quantidade de POPG, seguindo o nosso protocolo (seção 2.2.2), devido à grande quantidade de carga negativa de sua cabeça polar.

Inicialmente tentamos observar como o peptídeo híbrido impactava sobre a bicamada lipídica, misturando o mesmo na solução de GUVs previamente crescidas para posterior observação por MO. Entretanto, conforme vimos por vazamento de carboxifluoresceína no capítulo anterior, e também dos próprios resultados de $\mathrm{MO}$ a seguir, a cinética de poração é muito rápida (da ordem de segundos). Por este motivo, não conseguíamos visualizar e/ou precisar o início da interação. Na maioria dos casos, as GUVs já haviam sido destruídas durante o procedimento de colocar a amostra na cela de observação, que normalmente leva cerca de 1 minuto. Em alguns casos, para concentrações de peptídeos extremamente pequenas da ordem de nM, foi possível a visualização de algumas GUVs já parcialmente desestabilizadas durante a observação por MO.

Neste contexto, decidimos então injetar o peptídeo diretamente na solução de GUVs na cela de observação, através do sistema de micropipetas (figura 21), para tentarmos avaliar o início da interação peptídeo/membrana lipídica. Sendo assim, cerca de $3 \mu \mathrm{L}$ de solução contendo $1 \mathrm{mM}$ de peptídeos foi utilizada para a injeção do mesmo nas vizinhanças das GUVs. Todo o experimento foi gravado a uma velocidade de $10 \mathrm{fps}$ (fotos por segundo) e esse filme foi revertido em uma seqüência de fotos e apenas as mais relevantes estão sendo apresentadas nesse trabalho. É importante ressaltar que as fotos representam os efeitos que ocorreram com maior freqüência em todos os experimentos realizados. Mais ainda, não é possível comparar os diferentes experimentos, pois existem fatores ainda não controlados como, por exemplo, o fluxo de peptídeos na solução, a distância entre a pipeta e a GUV, o diâmetro da micropipeta, etc. De qualquer maneira, resultados qualitativos são muito importantes para inferir sobre o modo de ação deste peptídeo, complementando os resultados obtidos pelas outras técnicas utilizadas. 
A primeira seqüência de fotos está apresentada na figura 45. Ela apresenta três diferentes vesículas compostas por $57 \mathrm{~mol} \%$ de POPC e $43 \mathrm{~mol} \%$ de colesterol sob o efeito de $1 \mathrm{mM}$ (na micropipeta) do peptídeo híbrido. Nos três casos as membranas permaneceram por cerca de 15 segundos sob o efeito do fluxo de peptídeo (fotos não mostradas). Após esse tempo, ocorreu o rompimento das membranas, sem a visualização de um macroporo. Note que em todos os casos a membrana adere à superfície (últimas fotos das seqüências) e o resultado final é o da formação de um complexo, provavelmente formado por fosfolipídeo e peptídeo, aderido ao substrato. Neste caso expecífico, talvez o rompimento da membrana seja devido à adesão da mesma com o substrato.
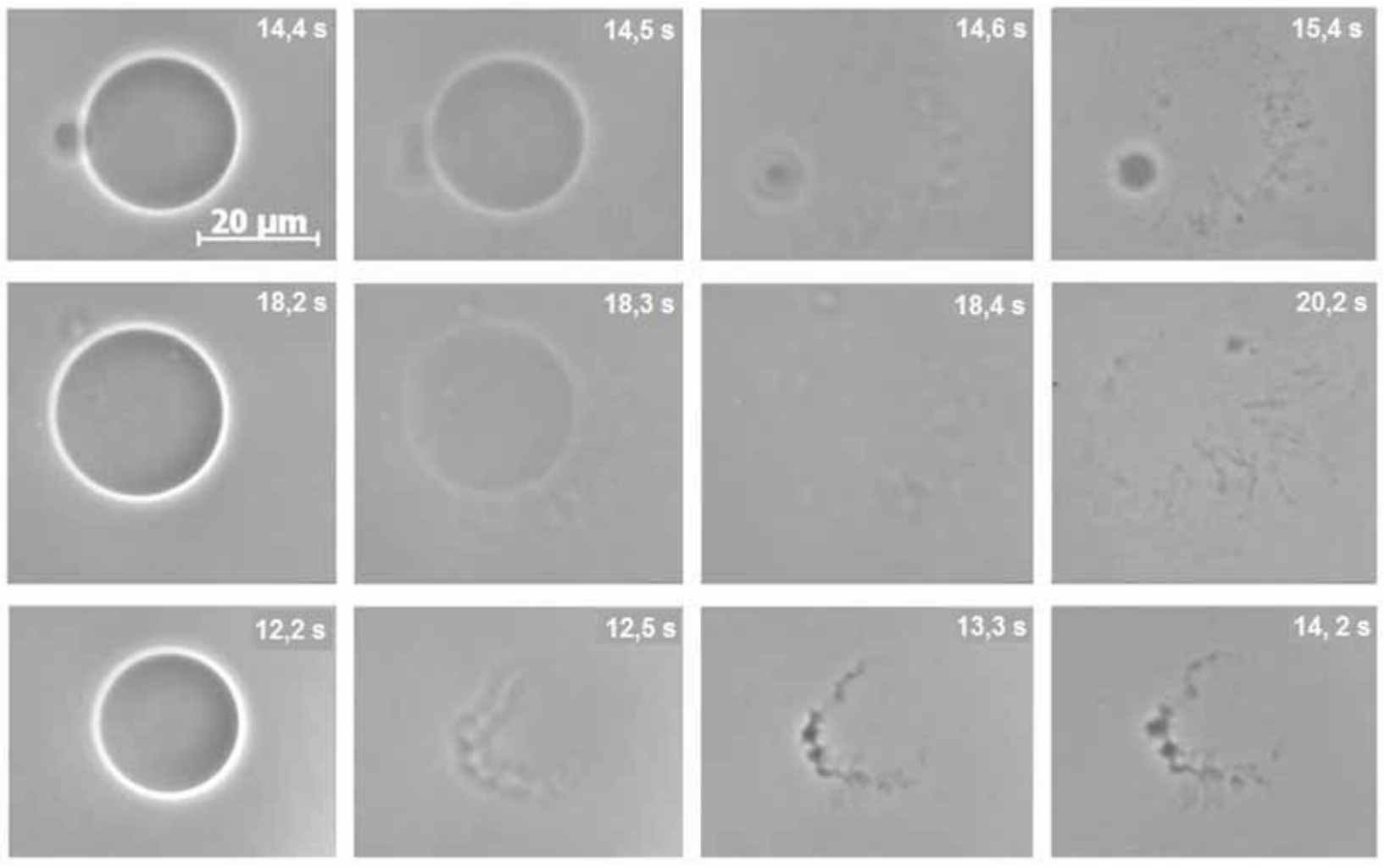

Figura 45 - GUVs composta por 57 mol\% de POPC e 43 mol\% de colesterol sob o efeito de $1 \mathrm{mM}$ de peptídeo híbrido (na micropipeta). Todas as fotos possuem a mesma escala.

Já a figura 46 apresenta uma seqüência de imagens de uma GUV, composta unicamente por POPC sob o efeito de $1 \mathrm{mM}$ de peptídeo híbrido, que adere ao substrato ( $3^{\mathrm{a}}$. e $4^{\mathrm{a}}$. foto na seqüência). Note que, a 3,6 s, um poro é visível na membrana (seta), sendo que a GUV começa a diminuir de tamanho e perder o contraste interior/exterior. Novamente, o processo final, em 
menos de $10 \mathrm{~s}$, resulta numa imagem representativa de fragmentos de membrana provavelmente complexados com os peptídeos.
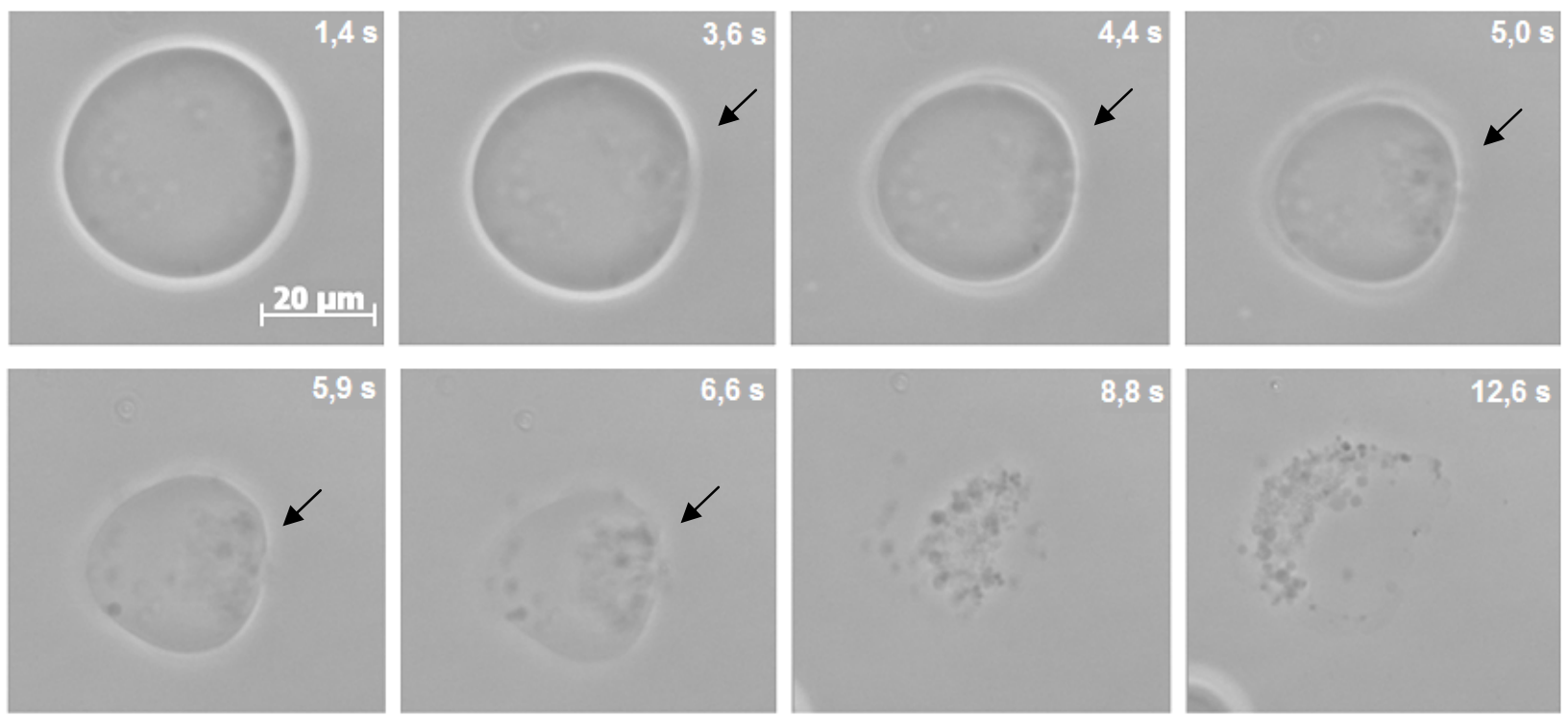

Figura 46 - GUV composta por POPC sob o efeito de $1 \mathrm{mM}$ de peptídeo híbrido.

A figura 47 apresenta agora fotos de uma GUV composta por POPC sob o efeito de $1 \mathrm{mM}$ de peptídeo híbrido. Nessa seqüência de fotos a GUV não adere à superfície, porém o efeito de abertura de poro é semelhante ao da figura 46 (seta). Mais ainda, note a presença de pontos mais escuros na superfície direita da membrana para um tempo de observação de 10,9 s, provavelmente relacionados à formação de agregados peptídeo/lipídeo ligados ainda à vesícula. 

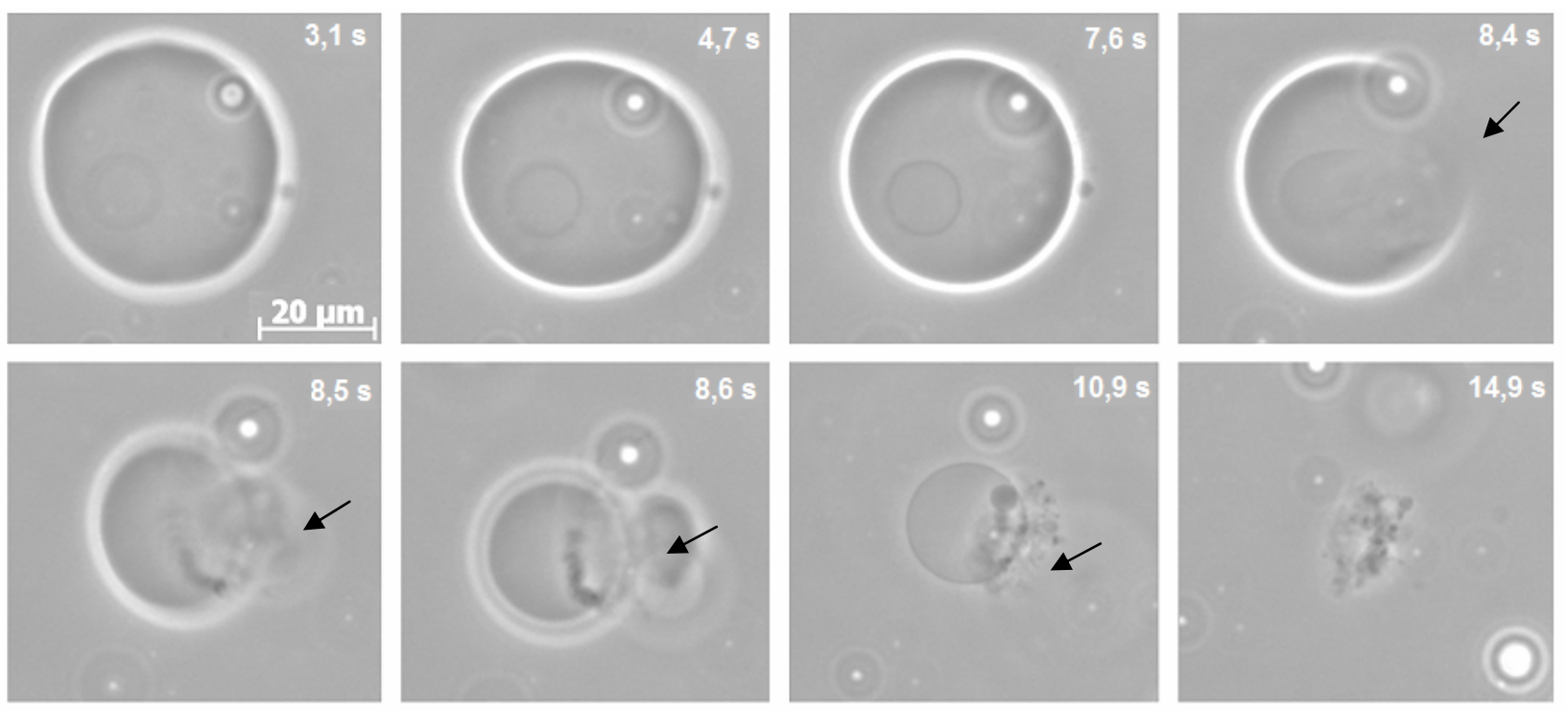

Figura 47 - GUV composta por POPC sob o efeito de $1 \mathrm{mM}$ de peptídeo híbrido.

Em termos de membranas lipídicas contendo carga negativa na superfície, a figura 48 apresenta imagens representativas de duas GUVs compostas por $20 \mathrm{~mol} \%$ de POPG e $80 \mathrm{~mol} \%$ de POPC. Ambas estavam sob a ação de um fluxo de $1 \mathrm{mM}$ de peptídeo híbrido por cerca de 2,5 segundos antes de observamos o início do rompimento das bicamadas. O fenômeno de desestabilização é muito rápido, resultando em destruição quase que imediata da membrana, sem percepção da abertura de um poro.
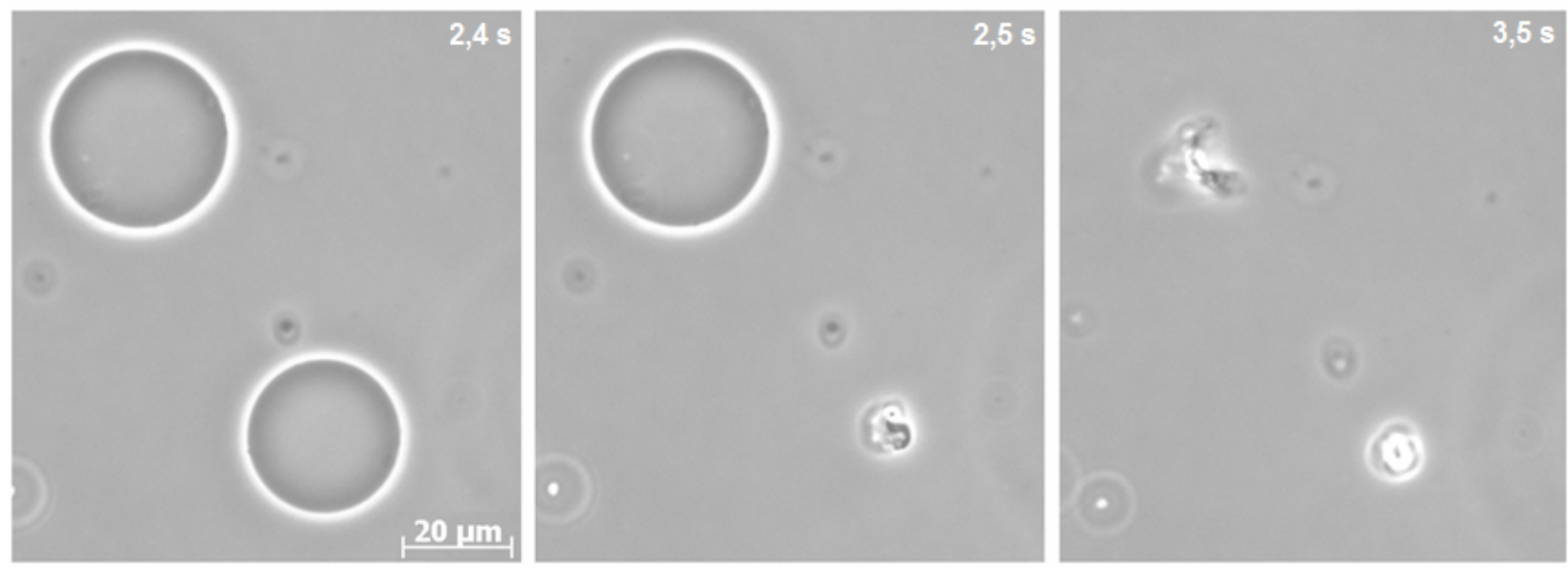

Figura 48 - GUVs compostas por 20 mol\% de POPG e 80 mol\% de POPC sob o efeito de $1 \mathrm{mM}$ de peptídeo híbrido. 
A figura 49 apresenta, por outro lado, uma seqüência de fotos da mesma amostra de 20 mol\% de POPG e $80 \mathrm{~mol} \%$ de POPC, aonde a abertura de um poro (seta) desestabiliza a membrana sob a ação da injeção de $1 \mathrm{mM}$ de peptídeo híbrido. Novamente, a partir da desestabilização da membrana, observamos como produto final a imagem de aglomerados complexos micrométricos na solução com morfologia mal definida.
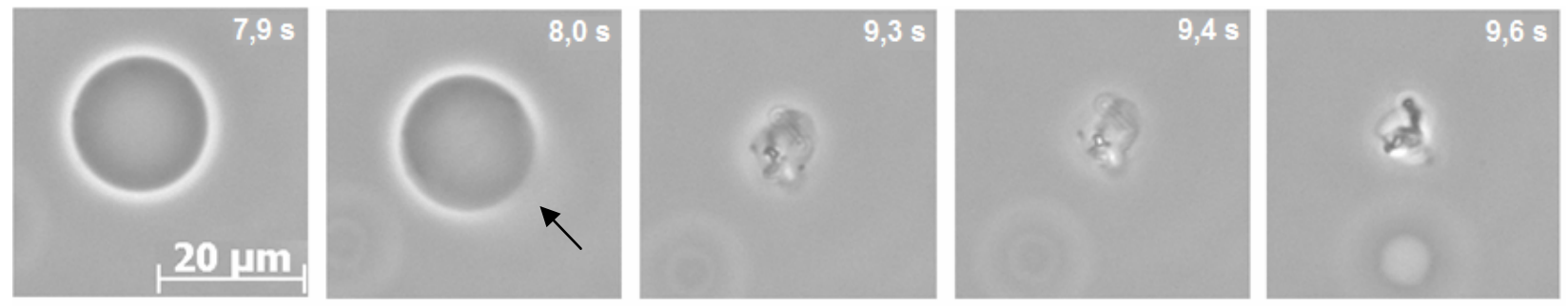

Figura 49 - GUV composta por 20 mol\% de POPG e 80 mol\% de POPC sob o efeito de 1 mM de peptídeo híbrido.

As figura 50 e 51 apresentam seqüências de fotos de 2 GUVs compostas por 50:50 POPG:POPC (mol\%). A formação de um poro "gigante" é bem evidente na figura 50 (seta), acompanhado pela formação de pequenos aglomerados ligados à bicamada inicialmente. Já na figura 51 a ação do peptídeo foi muito mais rápida, e observamos apenas o produto final de total solubilização da membrana.
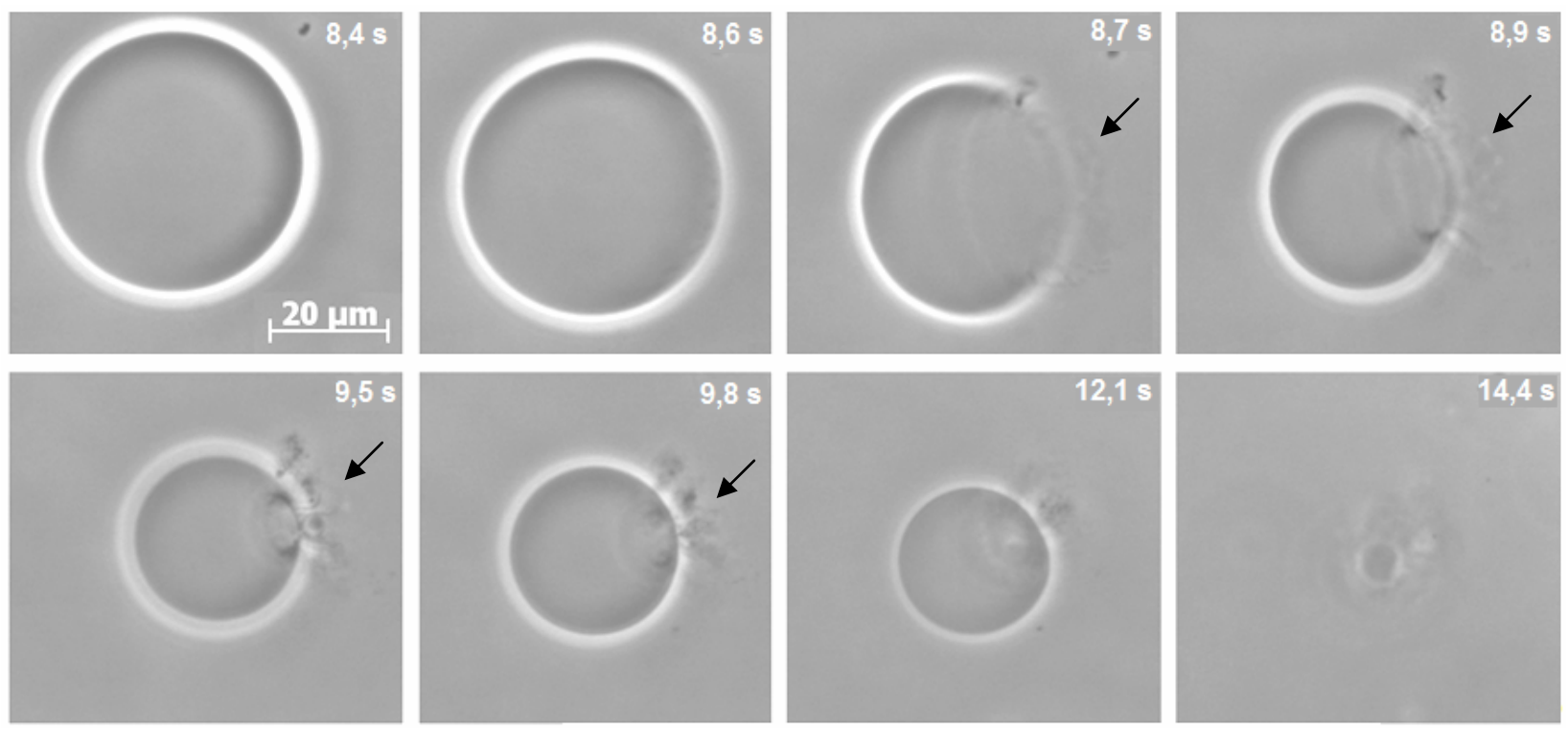

Figura 50 - GUV composta por 50 mol\% de POPG e 50 mol\% de POPC sob o efeito de $1 \mathrm{mM}$ de peptídeo híbrido. 

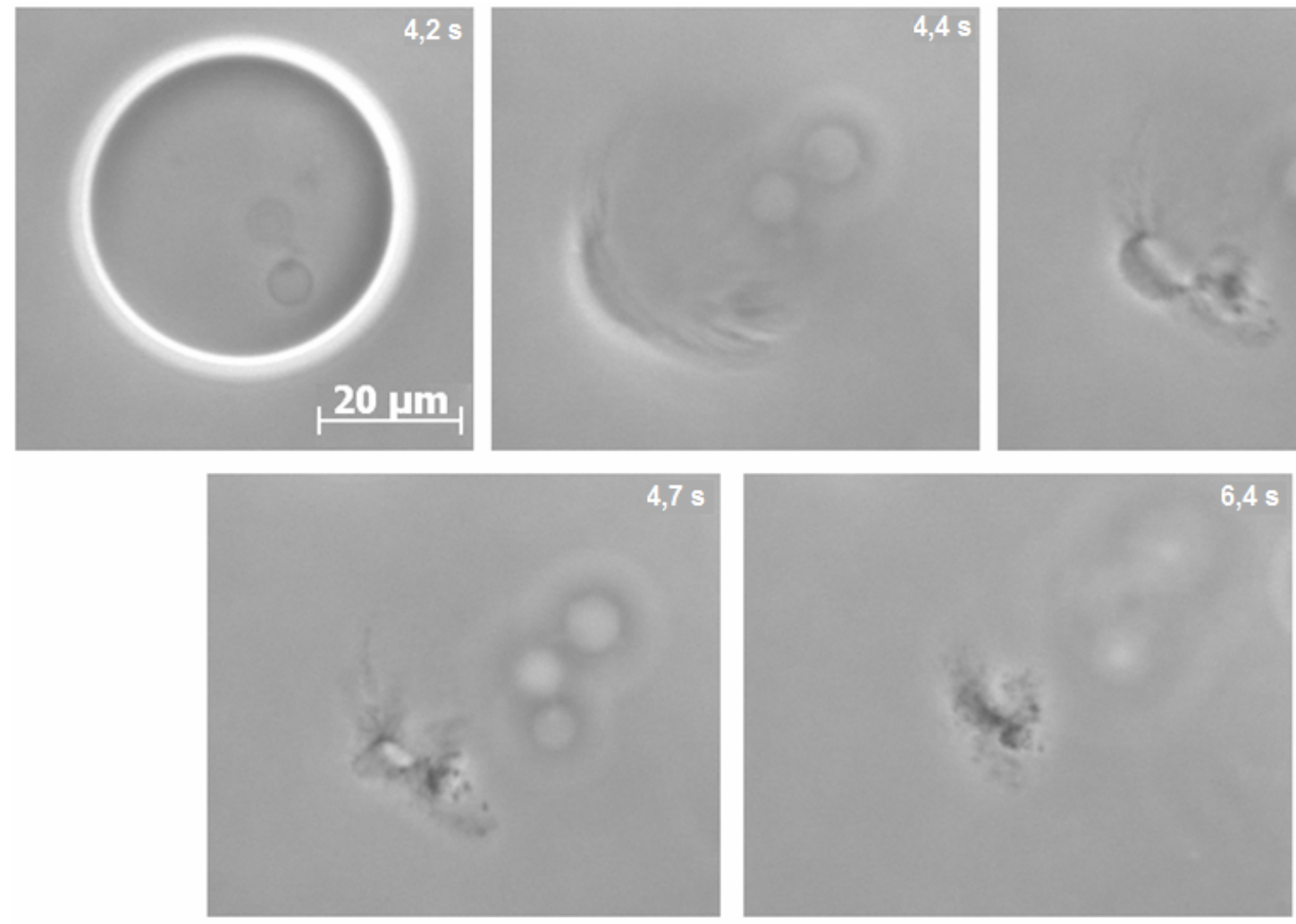

Figura 51 - GUV composta por 50 mol\% de POPG e 50 mol\% de POPC sob o efeito de 1 mM de peptídeo híbrido.

Portanto, o efeito final da interação do peptídeo híbrido com as membranas lipídicas, observado pelo microscópio óptico, foi sempre o rompimento das mesmas.

Em termos do papel do colesterol na membrana, observamos através da figura 45 que, provavelmente, as GUVs estouraram devido à adesão ao vidro e não ao efeito do peptídeo em sua bicamada. Esse fato foi reforçado quando GUVs de POPC foram observadas pelo modo RICM do microscópio óptico (o efeito de adesão à superfície também foi observado com essas membranas, como mostra a figura 46, porém ele é muito mais freqüente em membranas compostas com POPC e colesterol). A figura 52 apresenta fotos de uma GUV sob o efeito de $1 \mu \mathrm{M}$ (neste caso adicionada à solução de vesículas e não com o auxílio da micropipeta, para que a ação fosse mais lenta e possibilitasse essas imagens). Note que parte da membrana está aderida à superfície (dentro do círculo preto), e não apresenta flutuação entre uma foto e outra. Porém, a outra região da GUV ainda apresenta flutuações, mudando de característica de uma foto para a outra, apesar de manter o contorno externo fixo. Isto significa que, de certa forma, essa última região da membrana também está aderida à superfície. 

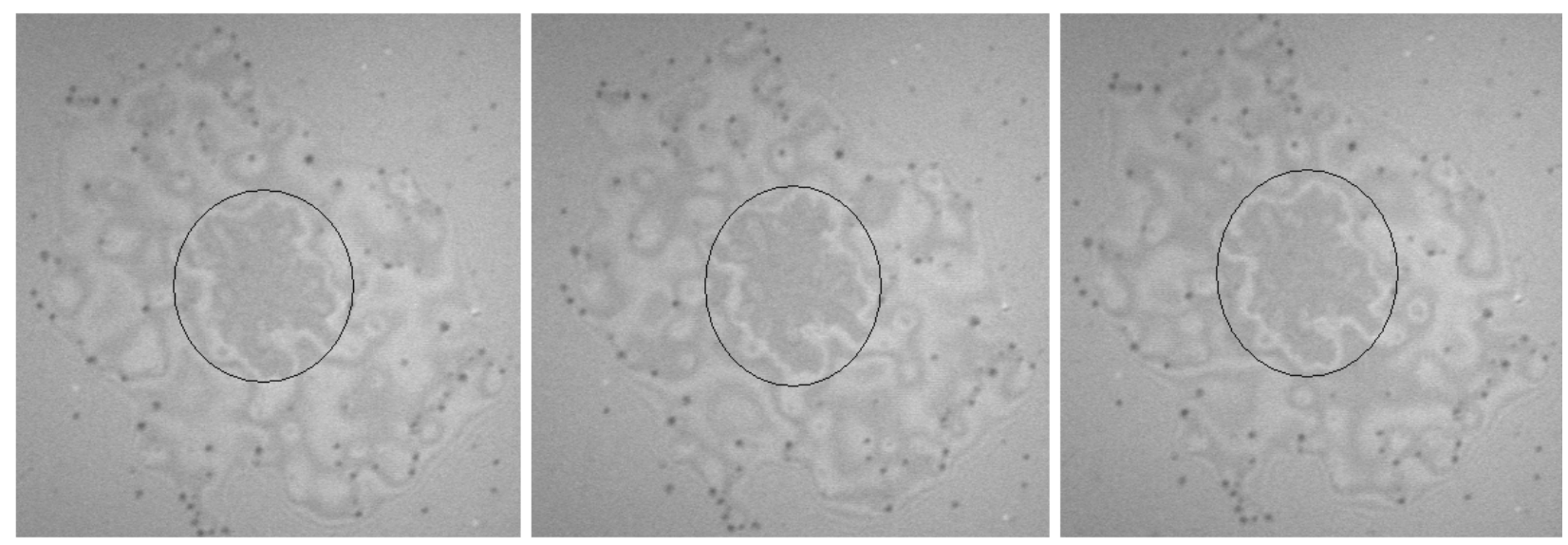

Figura 52 - GUV de POPC sob o efeito de $1 \mu \mathrm{M}$ de peptídeo híbrido (em solução), observada pelo modo RICM do microscópio óptico [Intitut Charles Sadron - Strasbourg, França].

De uma forma geral, os peptídeos devem interagir inicialmente com a monocamada externa da GUV, podendo se inserir parcialmente nessa camada, conforme nossos resultados espectroscópicos. Segundo os possíveis mecanismos de ação propostos para formação de poros em membranas lipídicas por peptídeos bactericidas (Figura 3), o primeiro passo consiste em haver um número de moléculas de peptídeos sendo adsorvidos num certo domínio da membrana. Isso deve levar a uma expansão da área da monocamada externa em relação à área inicial da mesma. Se a tensão induzida pelos peptídeos na monocamada externa for muito grande, ocorrerá ruptura da membrana e este processo deve se iniciar com a formação de um poro.

A maneira como as GUVs se desestabilizam (ver exemplo de explosão na figura 51) é muito similar à forma como uma GUV de POPC explode, devido ao efeito de injeção de dodecil sulfato de sódio (SDS), um detergente aniônico, utilizado nos testes preliminares para a implementação do sistema de micropipetas ao microscópio óptico. Esses resultados estão apresentados na seção a seguir, antes de concluirmos nosso trabalho.

\subsection{Interação de Membranas Modelo com Moléculas Anfifílicas}

Como já dito anteriormente, o início deste trabalho se deu a partir do estudo da interação de GUVs com moléculas anfifílicas (detergentes) com o intuito de praticar a injeção de soluções utilizando o sistema de micropipetas (figura 21). Os testes iniciais foram realizados com detergentes, como forma de aprendizagem para trabalhar com peptídeo, proteínas, etc., que são 
moléculas de interesse para o grupo. Este trabalho foi realizado com a colaboração da Profa. Dra. Karin A. Riske, do Departamento de Biofísica da UNIFESP.

Como as moléculas anfifílicas não foram introduzidas ao longo da dissertação, segue uma breve apresentação sobre elas. As moléculas anfifílicas são compostas por uma ou mais caudas de hidrocarbonetos, de natureza apolar, e uma cabeça polar. Os detergentes e os fosfolipídeos são exemplos dessas moléculas. Elas se auto-agregam, acima de uma dada concentração micelar crítica (cmc), devido a efeitos hidrofóbicos em meio aquoso, como mostrado na figura 53. Dependendo de sua geometria (figura 54), elas podem formar diferentes estruturas.

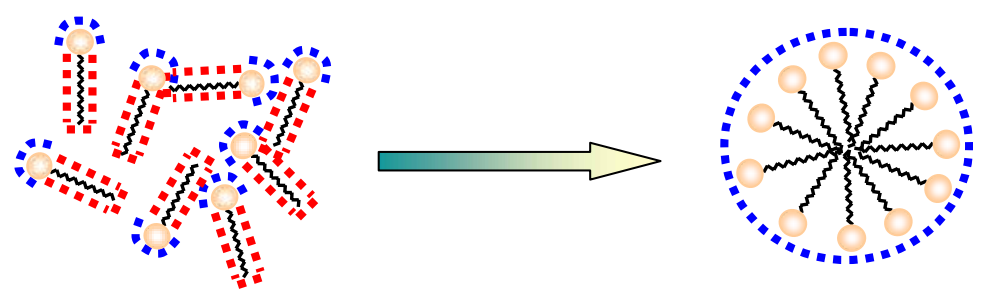

Figura 53 - Auto-agregação de um tipo de moléculas anfifílicas em meio aquoso. Os pontos azuis mostram as regiões hidrofílicas e os pontos vermelhos, as regiões hidrofóbicas.
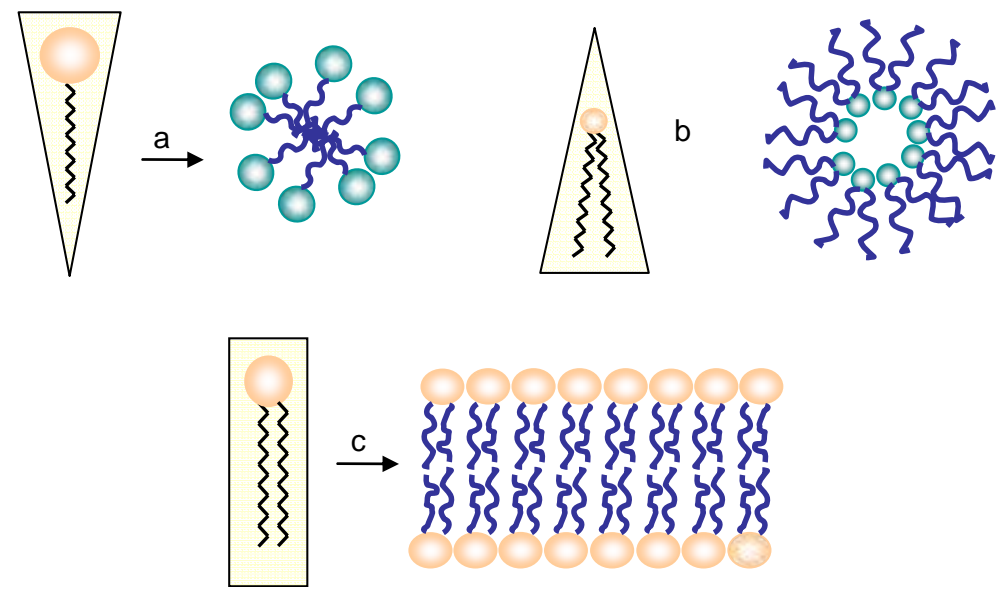

Figura 54 - Representação de três diferentes geometrias de moléculas anfifílicas. Em a) a molécula tem a forma de um cone e se agrega na forma de micela, em b) tem a forma de um cone invertido adquirindo a estrutura de micela reversa e em c) ela tem a forma de um cilindro, arranjando-se em bicamadas.

Geralmente os detergentes possuem apenas uma cadeia hidrofóbica agregando-se na forma de micela, ao contrário dos fosfolipídios que possuem pelo menos duas dessas cadeias e agregam-se na forma de bicamada. Mas, em ambos casos, as cadeias hidrocarbônicas ficam no interior da estrutura e a cabeça polar permanece exposta ao meio aquoso. 
Essa característica anfifílica torna os detergentes moléculas adequadas aos experimentos de incorporação em vesículas gigantes, pois sua porção apolar terá afinidade pela parte interna da bicamada. Deste modo, foi estudada a incorporação de detergentes em vesículas compostas exclusivamente por moléculas de POPC (figura 11) e, para facilitar a visualização, foram utilizadas membranas de POPC marcadas com 1 mol\% de DilC 18 , um marcador de membrana, já apresentado na figura 18.

Para entender essa interação, foram avaliados os efeitos de dois detergentes (SDS e Triton X-100) em vesículas gigantes, ambos observados ao microscópio óptico Zeiss Axionvert, descrito na seção 2.2.3. Para esse estudo foi utilizado o sistema de micropipetas, onde cerca de 3 microlitros de detergente foram colocados no interior de uma micropipeta de vidro e aproximados da vesícula, sem tocá-la, com a ajuda de um motor de precisão, como mostra a figura 21 . O fluxo de detergente permanece relativamente constante, porém sua concentração na superfície da vesícula não é conhecida.

Dos detergentes utilizados, o Triton X - 100 foi escolhido por ser não iônico e por ser bem conhecido na literatura que ele destrói membranas lipídicas [46, 47]. Por outro lado o SDS foi escolhido por ser aniônico e muito utilizado em indústrias de detergentes, de cosméticos, alimentícias. Suas estruturas estão apresentadas na figura 55. A concentração micelar crítica (cmc) do Triton X-100 é de $0,3 \mathrm{mM}$ e do SDS é de $8 \mathrm{mM}$.

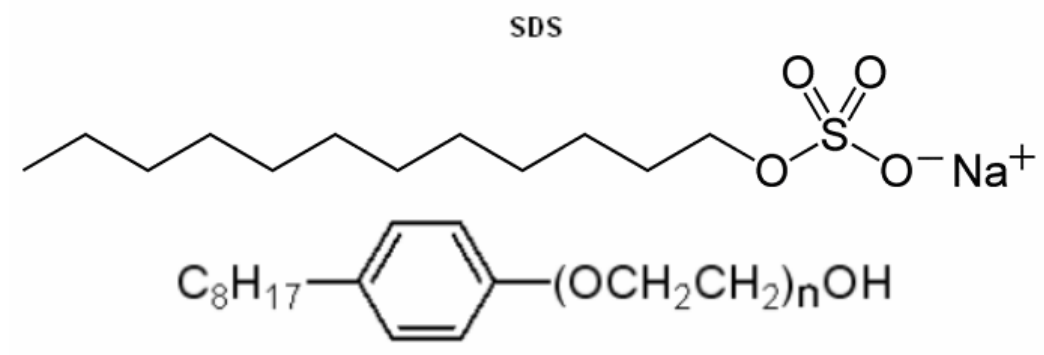

Triton X-100

Figura 55 - Estrutura do SDS e do Triton X-100.

Uma importante diferença entre o SDS e o Triton X - 100 é a taxa de flip-flop quando incorporados em uma bicamada lipídica. Sabe-se que o flip-flop de uma molécula se dá quando a mesma é transferida de uma monocamada para a outra. Essa taxa depende basicamente das características da cabeça polar do detergente, pois esta terá que ultrapassar toda a região 
hidrofóbica da bicamada. No caso do SDS, que é carregado negativamente, a taxa de flip-flop é baixa e pode ser desprezada, pois não ocorrerá no tempo da experiência [48]. Por outro lado, o Triton X - 100 possui uma taxa muito grande de flip-flop e o tempo para ocorrê-lo pode ser considerado instantâneo [49]. Essa característica é importante para a explicação dos diferentes efeitos que foram observados, uma vez que o detergente sempre será incorporado pela monocamada externa da GUVs. Dependendo do detergente e da concentração utilizada foi possível visualizar poros na bicamada ou até rompimento e total solubilização da mesma. Os resultados estão apresentados abaixo.

\subsubsection{Estudos Realizados com Triton $X-100$}

Foram realizadas experiências com diferentes concentrações de Triton X - 100 na micropipeta $(10,15,30$ e $60 \mathrm{mM})$. Porém, o efeito visualizado foi sempre o mesmo, independentemente da concentração. A figura 56 apresenta GUVs compostas por POPC sob o efeito de $15 \mathrm{mM}$ de Triton $\mathrm{X}-100$ na micropipeta.

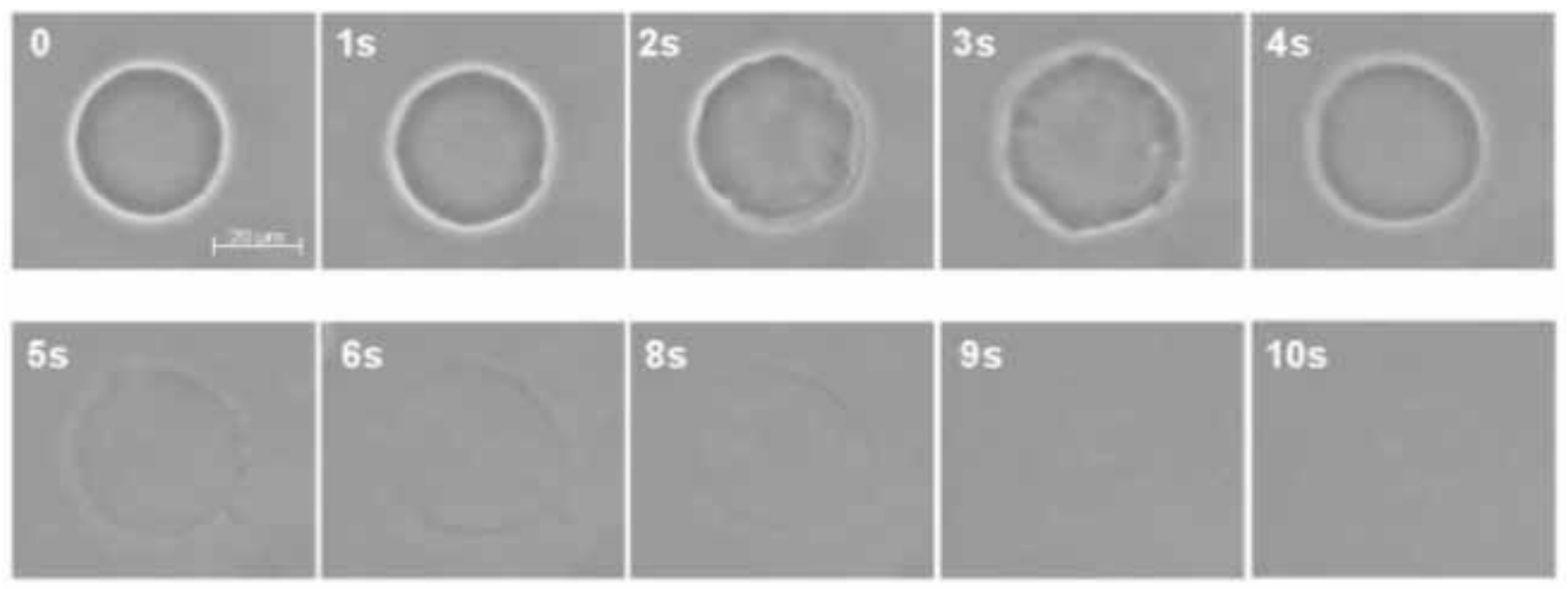

Figura 56 - Efeito de 15 mM de Triton X - 100 (na micropipeta) em GUVs compostas apenas por POPC.

Entre 1 e 3 s o detergente é incorporado na bicamada lipídica, aumentando a flutuação da membrana.

Em 4 segundos a GUV retoma uma forma mais próxima da inicial, porém com um contraste óptico menor. Em 5 segundos ela perde totalmente esse contraste e entre 6 e 10 segundos ocorre a total solubilização da bicamada lipídica.

Com essa mesma quantidade de detergente na micropipeta, foram realizadas experiências com vesículas gigantes multilamelares. A figura 57 apresenta esses resultados. Note que o 
contorno das vesículas é mais nítido no caso de multilamelas (setas brancas) do que em unilamelas. A imagem esbranquiçada à direita de todas as fotos é a micropipeta fora de foco.
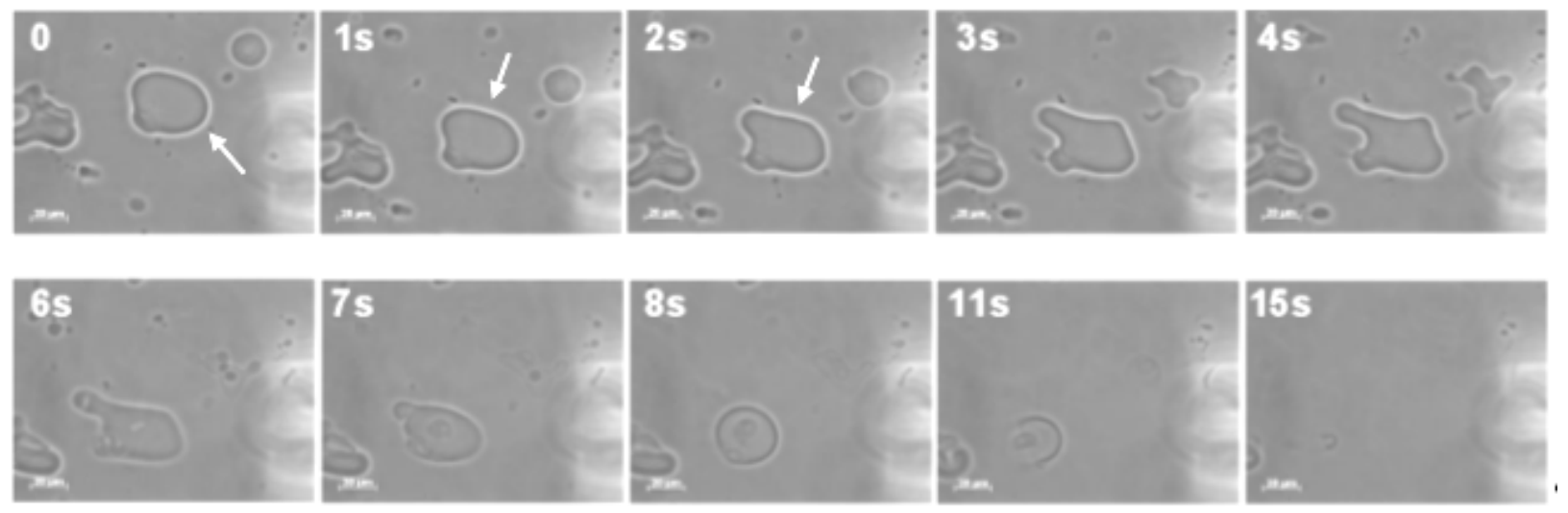

Figura 57 - Efeito de 15 mM de Triton $X$ - 100 (na micropipeta) em vesículas multilamelares gigantes compostas apenas por POPC.

Essa mesma experiência foi realizada com GUVs de POPC marcadas com $1 \mathrm{~mol} \%$ de DilC $_{18}$ para facilitar a visualização da solubilização da bicamada lipídica. Esse resultado está apresentado na figura 58. Ou seja, visualizamos uma grande flutuação inicial da membrana, seguida de sua destruição.
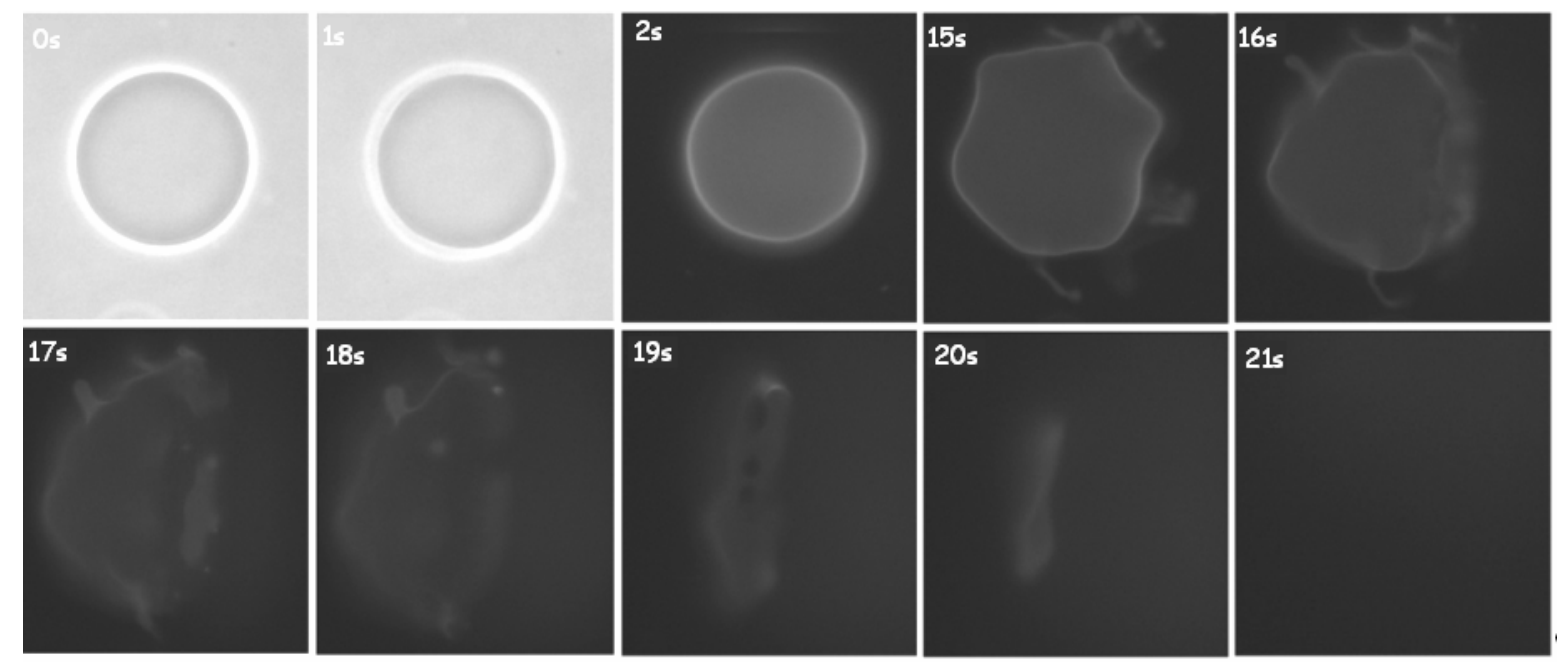

Figura 58 - Efeito de 15 mM de Triton X-100 (na micropipeta) em membranas fluorescentes, compostas por POPC e 1 mol\% de DilC 18 . Através da microscopia de fluorescência é mais fácil de acompanhar o processo de solubilização de membranas lipídicas. 
O efeito observado foi similar em todas as concentrações testadas. Inicialmente as vesículas apresentaram um aumento de área, que reflete em um aumento da flutuação da bicamada lipídica. Isso ocorre devido à incorporação do detergente pela monocamada externa e seu rápido flip-flop. O segundo fenômeno observado é a formação de buds (pequenas vesículas que permanecem ligadas às "vesículas mãe" por um pequeno pescoço), que fica evidente nas fotos com membranas fluorescentes. Isso ocorre devido ao excesso de área que a membrana tende a expulsar, para que a conformação onde o maior volume de solução ocupe a menor área superficial seja restabelecida, ou seja, a forma esférica. Em seguida, ela começa a perder o contraste óptico, provavelmente devido à criação de poros na membrana e, simultaneamente, a bicamada começa a desaparecer. Em cerca de 10 - 15 segundos, após a exposição da vesícula ao fluxo de detergente, ela é totalmente solubilizada e não é possível visualizá-la pelo microscópio, no modo contraste de fase.

De acordo com esses resultados observados, propomos um esquema de incorporação de Triton-X e destruição das vesículas na figura 59. Em um primeiro momento o detergente é incorporado na monocamada externa da membrana (figura 59.1) e ocorre um aumento de área aparente da vesícula. Devido ao rápido flip flop do Triton X - 100 pode-se afirmar que as moléculas de detergentes rapidamente se estabilizarão entre as duas monocamadas da vesícula (figura 59.3).

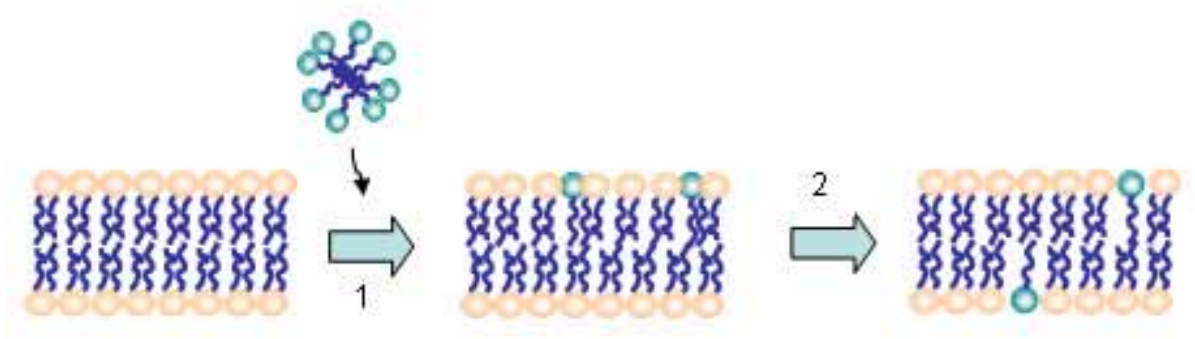

Figura 59 - Incorporação de Triton X - 100 na bicamada lipídica.

Quando existir um domínio de Triton X-100 (como indica a seta na figura 60) em uma das bicamadas da membrana é possível que microporos se abram, devido à geometria da molécula de detergente, criando um microcanal. Este permite que ocorra uma troca de material do meio externo e interno da membrana, o que justifica a perda do contraste óptico evidente nas imagens 
de microscopia de contraste de fase. Quando vários desses microtubos se abrirem ocorrerá a desestabilização da membrana e ela se romperá em vários pontos, fazendo com que a GUV desapareça rapidamente. Os fragmentos de bicamada serão incorporados nas micelas de detergente, como mostrado na figura 60 .

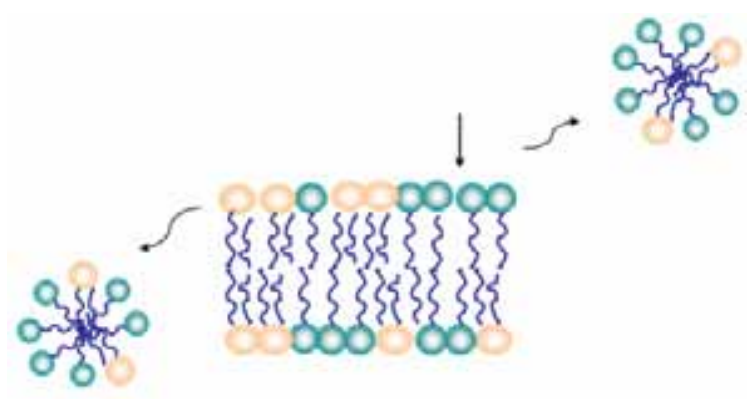

Figura 60 - Representação de possíveis domínios de Triton X -100 na bicamada lipídica. Devido à sua geometria é possível que nessa região seja formado um microcanal.

\subsubsection{Estudos Realizados com SDS}

Foram realizadas experiências com diferentes concentrações de SDS e três condições distintas foram observadas, utilizando concentrações de 18, 30 e $56 \mathrm{mM}$ na micropipeta. As membranas utilizadas são compostas por POPC e POPC com 1 mol\% de DilC 18 .

A figura 61 apresenta uma seqüência de imagens de GUVs de POPC sob o efeito de 18 $\mathrm{mM}$ de SDS na micropipeta.
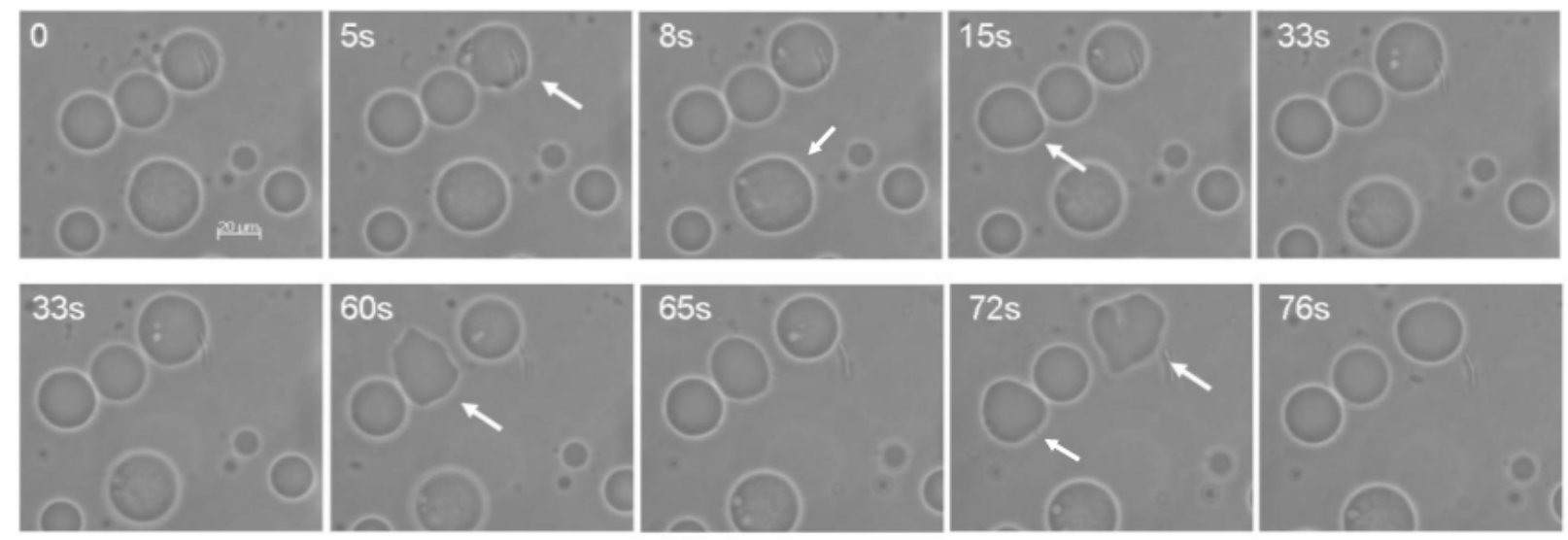

Figura 61 - GUVs sobre o efeito de $18 \mathrm{mM}$ de SDS (na micropipeta). As setas brancas indicam o aumento de área das GUVs. 
A figura 62 apresenta o efeito de $30 \mathrm{mM}$ de SDS na micropipeta em GUV de POPC. A seta indica a abertura de um grande poro na vesícula. É possível visualizar, através da gravação feita com o sistema de aquisição do microscópio, um fluxo de dentro para fora das membranas, no período em que o poro permanece aberto.
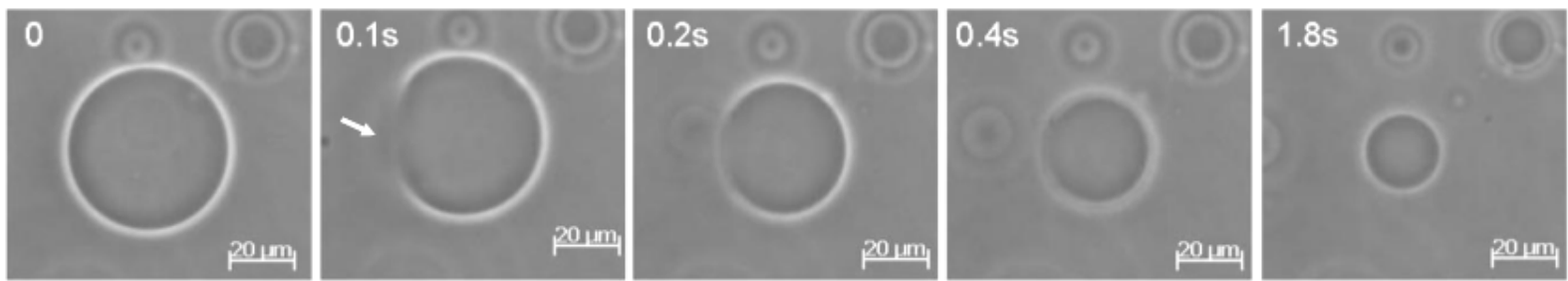

Figura 62 - Efeito de 30 mM de SDS (na micropipeta) em contato com GUVs de POPC.

Por fim, a figura 63 apresenta as GUVs sobre o efeito de $54 \mathrm{mM}$ de SDS na micropipeta. A ação é muito rápida e ocorre a total desestabilização da bicamada lipídica. Esse mesmo efeito foi acompanhado com membranas fluorescentes figura 64.
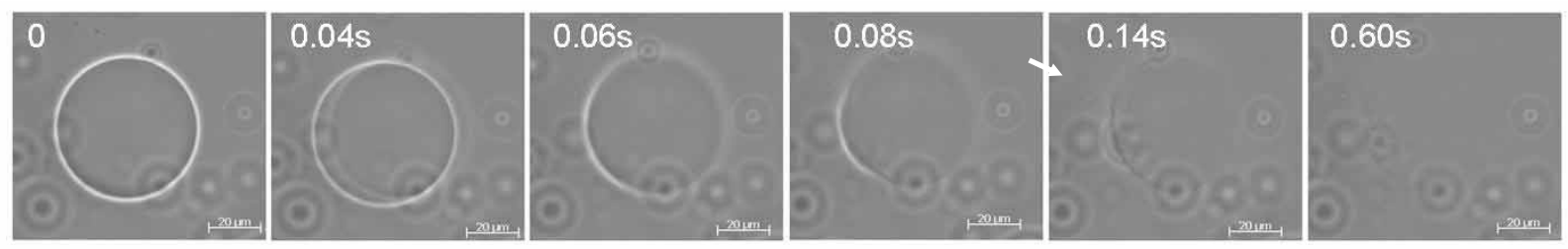

Figura 63 - Seqüência de imagens da explosão de uma GUV sob efeito de 54 mM de SDS (na micropipeta). 

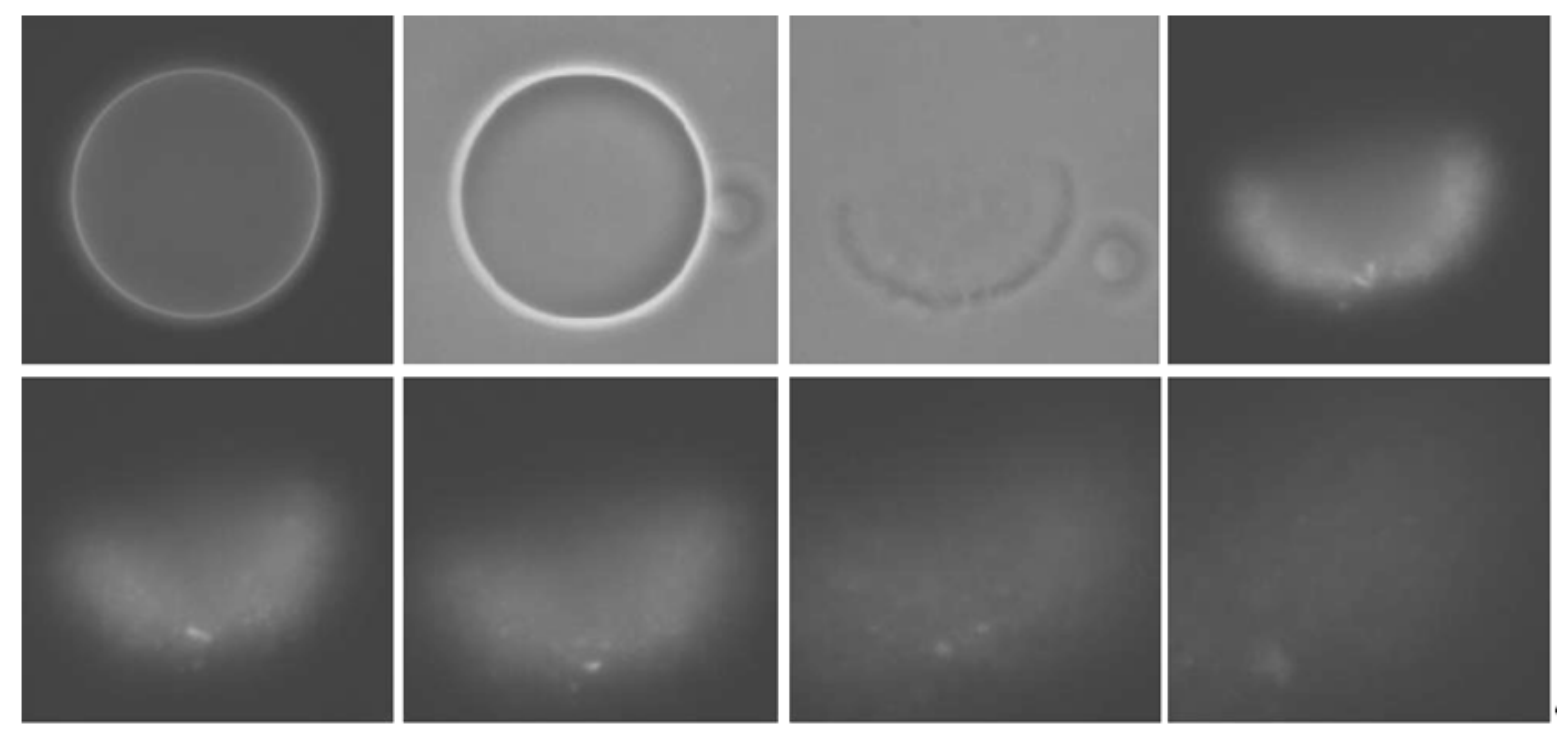

Figura 64 - Imagens da explosão de um GUV fluorescente, sob o efeito de 54 mM de SDS na micropipeta.

Dos resultados acima, identificamos três diferentes efeitos. O primeiro observado foi sob a concentração de $18 \mathrm{mM}$ de SDS na micropipeta. Com essa concentração, a vesícula parece “respirar”. Nessa condição a vesícula não explode com o fluxo de detergente, mas apresenta mudanças morfológicas cíclicas, com um período da ordem de segundos, e uma ligeira perda de contraste óptico. Essas mudanças passam por um aumento de área, assim como ocorre com o Triton $\mathrm{X}-100$, formação de buds e uma aparente reincorporação desses buds.

A formação de buds pode ser explicada com o diagrama da figura 65. O eixo y desse gráfico representa a assimetria de área superficial entre as duas monocamadas ou uma curvatura intrínseca que a bicamada gostaria de possuir $\left(\Delta A_{0}\right)$ e o eixo x representa o volume real da vesícula dividido pelo volume que essa mesma área teria se fosse uma esfera. Desta maneira, os buds aparecem quando a vesícula tem um aumento de curvatura espontânea ou ganha um excesso de área muito rapidamente [50]. 


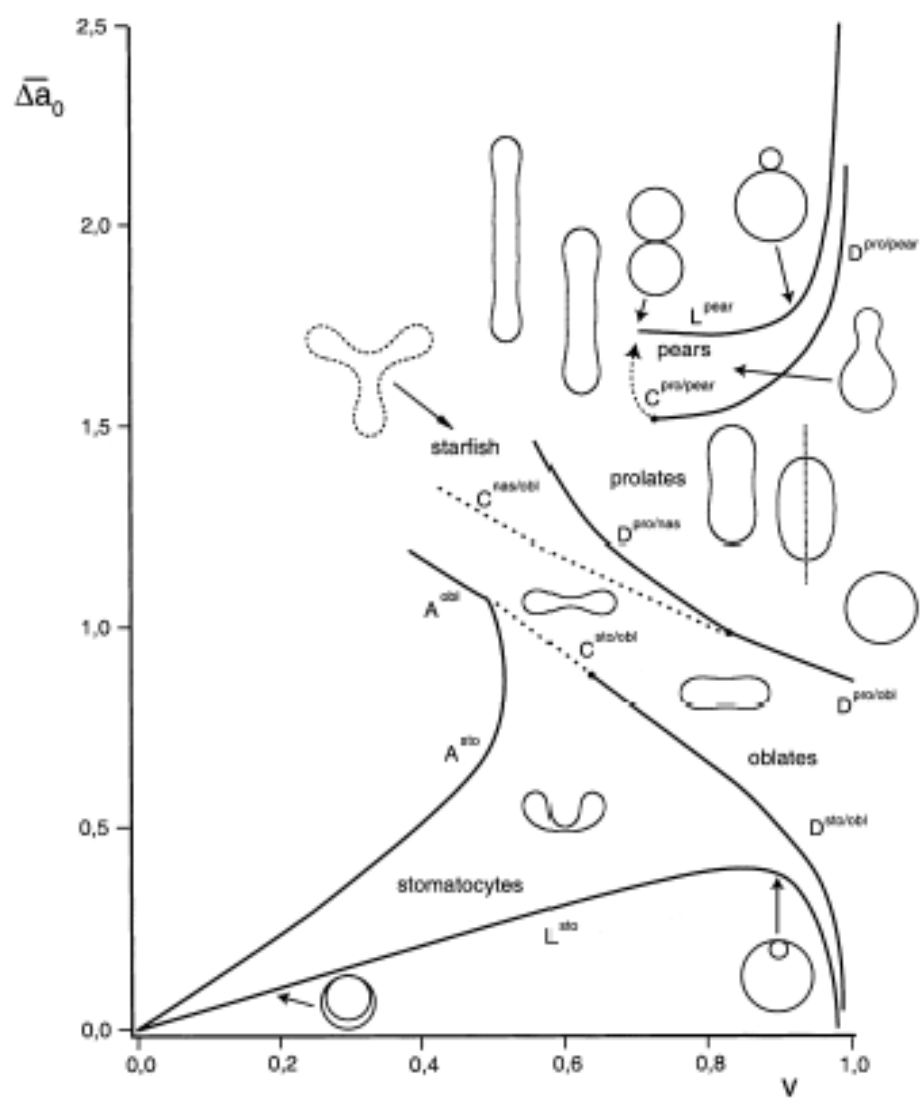

Figura 65 - Diagrama que expõe as possíveis formas que as vesículas podem adquirir de acordo com a relação volume/área e a curvatura espontânea. Figura extraída de [50].

A segunda concentração utilizada foi de $30 \mathrm{mM}$ de SDS na micropipeta. Com esse aumento de concentração foi possível observar a abertura e fechamento de poros nas vesículas. As GUVs não são destruídas, apenas diminuem visivelmente de tamanho. Esse processo é muito rápido, os poros permaneceram abertos por $\sim 200 \mathrm{~ms}$. Ainda sim foi possível observar um fluxo de sacarose proveniente da vesícula e, por esse motivo, a assimetria de açúcar é conservada.

Com a maior concentração estudada, 54 mM SDS, o observado foi a rápida destruição das vesículas, como mostrado na figura 63. O que ocorre, provavelmente, é o aparecimento de vários poros em toda a bicamada, desestabilizando-a inteiramente. Ela é destruída em menos de $150 \mathrm{~ms}$, após a aproximação do fluxo contínuo de detergente. Na imagem é possível visualizar grande parte da bicamada (seta branca), mostrando que ela ainda não foi completamente solubilizada. Essa mesma experiência foi acompanhada com membranas fluorescentes, como as da figura 64. 
Nessa figura foi possível visualizar os fragmentos de membranas após a total solubilização da bicamada lipídica.

Nossas observações nos dão suporte para propor um modelo de ação do SDS na membranas: inicialmente, uma certa quantidade de detergente é incorporada na bicamada (figura 66.1). Devido à rápida difusão lateral dos lipídeos e detergentes é possível que algumas moléculas de SDS se agrupem (figura 66.2) e, simultaneamente a isso, a bicamada lipídica se curvará para acomodar as moléculas de detergente que estão apenas na monocamada externa (figura 66.3). Como já mostrado na mostrado na figura 54, o SDS tenderá a formar uma estrutura tipo micela devido à sua geometria. Sendo assim, é possível que vários poros sejam formados na membrana (figura 66.4).

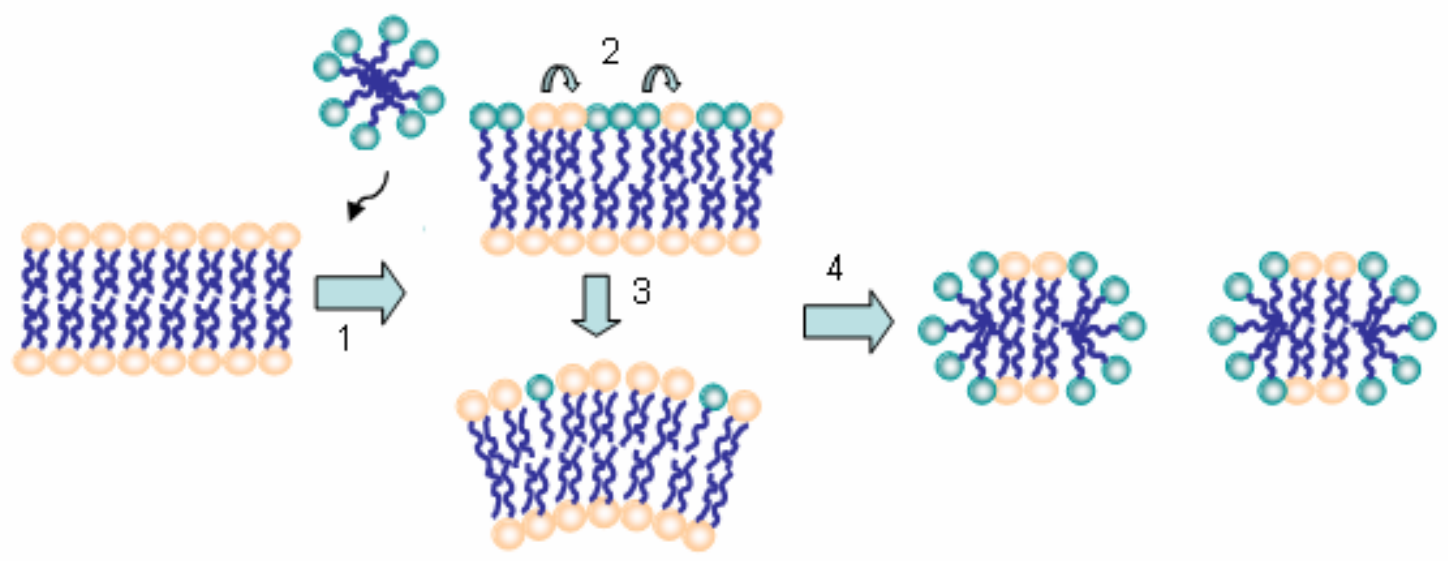

Figura 66 - Incorporação de SDS na bicamada lipídica.

Fazendo uma discussão geral sobre detergentes, podemos dizer eles possuem ação bem distintas. Certamente isso se deve ao fato de que, como já dito anteriormente, o SDS não realiza flip-flop no tempo da experiência e o Triton X-100 realizá-lo praticamente no momento em que é incorporado pela bicamada lipídica. Assim, todo o SDS que é incorporado pela GUV permanecerá na monocamada externa dessa membrana, enquanto que o Triton X-100 conseguirá migrar para a monocamada interna, balanceando, assim, a quantidade de moléculas entre as duas monocamadas da membrana e aumentando consideravelmente a área da bicamada. Com o acúmulo de uma certa quantidade de SDS na monocamada externa, a membrana não suportará essa assimetria de moléculas entre a monocamada externa e a interna, gerando uma tensão na membrana que ultrapassa a tensão de lise (figura 63 e figura 64) ou abrirá poros que, 
ocasionalmente, se fecharão (figura 62). Se a quantidade de SDS for baixa suficiente para que a ação do detergente não seja tão rápida, de alguma forma a monocamada externa conseguirá expelir, na forma de buds, essa quantidade de moléculas que "sobra" nessa monocamada. Assim, o efeito visualizado é como o da figura 61, onde a vesícula parece "respirar".

\subsection{Efeito do peptídeo híbrido em GUVs em comparação com o dos detergentes}

De acordo com os nossos resultados, podemos perceber que o peptídeo híbrido deve atuar nas membranas lipídicas de modo similar à ação do SDS, sem translocação da membrana externa para a membrana interna da GUV. Essa suposição vem do fato de acreditarmos que cada região do peptídeo ( $\mathrm{N}$ - terminal e $\mathrm{C}$ - terminal) deve manter a sua estrutura e função original, ou seja, a região proveniente da pediocina A deverá ser responsável pela ancoragem do peptídeo na membrana e a região proveniente da plantaricina 149 deverá ser responsável pela formação da hélice anfipática, que possivelmente se "enterrará" na bicamada lipídica. Porém, a região entre os resíduos 16 e 32, com 50\% de probabilidade de formar estrutura secundária tipo helicoidal (figura 7), possui apenas 17 aminoácidos. Como cada aminoácido, quando está na forma de uma $\alpha$ hélice ideal, tem comprimento de $\sim 0,15 \mathrm{~nm}$ [51], essa região possui um comprimento estimado de $\sim 2,55 \mathrm{~nm}$. Tal dimensão é compatível com a espessura de uma monocamada lipídica [51]. Portanto, o peptídeo deve ancorar na monocamada externa da membrana e interagir apenas com ela, assim como o SDS. A principal diferença entre eles é que a ação do peptídeo apenas ocorrerá depois que alguns deles se estruturem e entrem na bicamada lipídica. Com o aumento da pressão lateral dos fosfolipídeos induzido pela incorporação dos peptídeos, a membrana se desestabiliza e rompe, procedida por uma reassociação de fosfolipídeos e peptídeos em estruturas mistas solubilizadas na solução aquosa, como visualizado em praticamente todos os nossos experimentos por MO.

Nossos dados revelam assim que o peptídeo híbrido estudado não forma poros estáveis em membranas, como observado por outros tipos de peptídeos anfipáticos [52, 53] e algumas toxinas [43]. Por outro lado, nossos resultados são muito similares ao de interação de GUVs com algumas catequinas de chá, que são flavonóides e principais componentes do extrato de chá verde, que também possuem atuação antibactericida e atividade antioxidante [54]. 


\section{Conclusões e Perspectivas Futuras}

Esse trabalho investigou a interação entre o peptídeo híbrido da plantaricina 149 e da pediocina A com membranas lipídicas modelo.

Através dos resultados das medidas espectroscópicas podemos concluir que o peptídeo híbrido interage com membranas lipídicas compostas por fosfolipídeos contendo cabeça polar de fosfatidilcolina, fosfatidilglicerol e membranas mistas, tal que, a intensidade de sua interação é dependente da quantidade de carga negativa na superfície da membrana. Isto é, nossos resultados de $\mathrm{CD}$ e fluorescência nos deram suporte para concluir que, para a mesma razão molar peptídeo/lipídeo $(0,025)$, o peptídeo híbrido carregado positivamente a $\mathrm{pH} 7,4$, passa de uma conformação desordenada em solução aquosa para uma conformação parcialmente helicoidal quando interage com a membrana lipídica. Esta transição é mediada pela presença de duas populações, uma desenovelada e outra parcialmente enovelada, tal que esta última é maior quanto maior for a quantidade de carga na membrana. Mais ainda, a região do peptídeo (aminoácidos 16 a 32 - figura 7) que forma a estrutura helicoidal deve interagir fortemente com o interior hidrofóbico da membrana lipídica como evidenciado pelos resultados de fluorescência do triptofano. Como esta parte da estrutura contém muitos resíduos de lisina (K) (Figura 4), e estes são polares, acreditamos que a inserção da região helicoidal se dá de tal maneira a expor estes resíduos à solução aquosa, associado a formação de poros.

Os dados de vazamento de carboxifluoresceína evidenciaram a formação de poros como mecanismo de ação destes peptídeos em membranas. Novamente, o papel das cargas na membrana mostrou-se fundamental, pois os dados experimentais revelaram que a quantidade de peptídeo disponível na solução e necessária para induzir poros nas membranas é menor quanto maior a quantidade de carga negativa na membrana lipídica. Interessantemente, quanto maior a porcentagem de PG na membrana, o efeito de poração é mais rápido e efetivo. Ou seja, o papel das cargas negativas na superfície de membranas de bactérias deve ser fundamental para a atuação deste tipo de peptídeo bactericida. Por outro lado, nossos resultados com membranas contendo colesterol, mimetizando membranas de eritrócitos, mostram uma diminuição da efetividade do peptídeo na formação de poros na membrana.

Nossos resultados isolados não são suficientes para podermos inferir nem o tamanho dos poros nem sua estabilidade. Ou seja, se o peptídeo se insere na membrana, forma poro, sem 
romper a membrana de maneira drástica, ou se sua inserção desestabiliza a bicamada lipídica levando à lise da mesma, devido a um grande aumento da tensão superficial.

Para tentarmos inferir melhor sobre o mecanismo de ação do peptídeo híbrido estudado, utilizamos então o recurso de visualização de GUVs por microscopia óptica. Embora não tenhamos conseguido o controle eficaz do experimento, em termos de quantidade de lipídeo:peptídeo na interface da membrana, as imagens evidenciaram que os poros formados não são estáveis, existe desestabilização muito rápida da membrana (da ordem de segundos) quando o peptídeo é exposto numa solução que contém as GUVs, onde podemos observar dois cenários majoritariamente. São eles: i) formação de poros com subseqüente diminuição do volume da vesícula até desaparecer totalmente no campo de visão; ii) destruição rápida da vesícula sem a percepção de abertura de poros micrométricos. Em ambos os casos, o cenário final é de um aglomerado misto de fosfolipídeo/peptídeo de forma não definida, solubilizados em solução aquosa.

\section{Perspectivas Futuras:}

1. Refazer o experimento de fluorescência do triptofano, utilizando diferentes relações de peptídeo/lipídeo para aquisição de dados que possibilitem a obtenção da constante de ligação do peptídeo nas diferentes bicamadas lipídicas.

2. Cálculo da concentração de lipídeo na superfície das diferentes membranas, para comparação com os dados da razão peptídeo/lipídeo obtida nesse trabalho.

3. Investir no método de microscopia óptica, uma vez que um novo equipamento deverá ser adquirido no próximo ano, com um sistema bem mais completo de micropipetas. Este permitirá estimar aumento de área, tensão superficial da membrana, etc.

4. Redação de dois artigos científicos: um sobre as observações realizadas com GUVs e detergentes e outro sobre todos os resultados apresentados nesta dissertação sobre a interação do peptídeo híbrido bactericida e membranas lipídicas. 


\section{Referências}

[1] BROWN, K. L, AND HANCOCK, R. E. W., Cationic Host Defense (Antimicrobial) Peptides, Current Opinion in Immunology, v. 206, n. 2, p. 143 - 149, 2006.

[2] HANCOCK, R. E. W. AND SAHL, H. G., Antimicrobial and Host-defense Peptides as New Anti-infected Therapeutic Strategies, Nature Biotechnology, v. 24, n. 112 , p. $1551-1557,2006$.

[3] HOPP, T. P. AND WOODS, K. R., Prediction of protein antigenic determinants from amino acid sequences, Proceeding of the National Academy of Sciences, v. 78, n. 6, p. $3824-3828,1981$.

[4] UNESP. Alimentos - Bioquímica - Tabelas de aminoácidos. Disponível em http://www.fcfar.unesp.br/alimentos/bioquimica/imagens/TABELA AA.GIF. Acessado em 03/03/2009.

[5] JENSSEN, H., HAMIL, P. AND HANCOOK, R. E. W., Peptide Antimicrobial Agents, Clinical Microbiology Reviews, v. 19, n. 3, p. 491 - 511, 2006.

[6] MARR, A.K.M GOODERHAM, W. J., HANCOOCK, R.E W, Antibacterial Peptides for Therapeutic Use: Obstacles and Realistic Outlook, Current Opinion in Pharmacology, v. 6, n. 5, p. 468 - 472, 2006.

[7] MÜller, D. M.; CARRASCO, M. S.; SIMONETTA, A. C., et al, A Synthetic Analog of Plantaricin 149 Inhibiting Food-borne Pathogenic Bacteria: Evidence for $\alpha-$ helical Conformation Involved in Bacteria-membrane Interaction, Journal of Peptide Science, v. 13, n. 3, p. $171-178,2007$.

[8] LUBELSKI, J.; RINK, R.; KHUSAINOV, R., et al, Biosynthesis, Immunity, Regulation, Mode of Action and Engineering of the Model Lantibiotic Nisin, Cellular and Molecular Life Sciences, v. 65, n. 3, p. $455-476,2008$.

[9] MARR, A. K, GOODERHAM W. J. AND HANCOCK, R. E. W., Antibacterial Peptides for Therapeutic Use: Obstacles and Realistic Outlook, Current Opinion in Pharmacology, v. 6, n. 5, p. $468-472,2006$.

[10] KATO, T.; MATSUDA, T.; OGAWA, E., et al, Plantaricin-149, a bacteriocin produced by Lactobacillus plantarum NRIC 149, Journal of Fermentation and Bioengineering, v. 77, n. 3, p. $277-282,1994$. 
[11] INNOVAGEN. Peptide Property Calculator. Disponível em: $<$ http://www.innovagen.se/custom-peptide-synthesis/peptide-property-calculator/peptideproperty-calculator.asp $>$. Acessado em: 21/11/2008.

[12] RODRÍGUEZ, J. M., MARTÍNEZ, M. I. AND KOK, J., Pediocin PA-1, a WideSpectrum Bacteriocin from Lactic Acid Bacteria, Critical Reviews in Food Science and Nutrition, v. 42, n. 2, p. $91-121,2002$.

[13] CINTAS, L. M.; CASAUS, P.; FERnANDEZ, M. F., et al, Comparative Antimicrobial Activity of Enterocin L50, Pediocin PA-1, Nisin A and Lactocin S Against Spoilage and Foodborne Pathogenic Bacteria, Food Microbiology, v. 15, n. 3, p. 289 298, 1998.

[14] CHEN, Y., LUDESCHER, R. D. AND MONTVILLE, T. J., Electrostatic Interactions, but Not the YGNGV consensus Motif, Govern the Binding of Pediocin PA 1 and Its Fragments to Phospholipid Vesicles, Applied and Environmental Microbiology, v. 63, n. 12, p. $4770-4777,1997$.

[15] MULLER, D. M. et al, Búsqueda de Nuevos Antimicrobianos Mediante el Disenõ de Péptidos Híbridos Constituídos por Fragmentos de Bacteriocinas de Diferentes Clases. Apresentado em CYTAL Congress 2007.

[16] Professora Dra. Georgina Tonarelli - comunicação pessoal.

[17] FAZIO, M. A.; JOUVENSAL, L.; VOVELLE, F., et al, Biological and Structural Characterization of a New Linear Gomesin Analogues With Improved Therapeutic Indices, Peptide Science, v. 88, n. 3, p. 386 - 400, 2006.

[18] REDICTPROTEIN - Structure Prediction and Sequences Analyses. Disponível em $<$ http://www.predictprotein.org $>$. Acessado em 28/11/2008.

[19] NAGLE, J. F. AND TRISTAM-NAGLE, S., Structure of Lipid Bilayers, Biochimica et Biophysica ACTA Reviews on Biomembranes, v. 1469, n. 3, p. 159 - 195, 2000.

[20] LEE, A.G., How Lipids Interact with an Intrinsic Membrane Protein: The Case of the Calcium Pump, Biochimica et Biophysica ACTA Reviews on Biomembranes, v. 1376, n. 3, p. $381-390,1998$.

[21] AGARRABERES, F. A. AND DICE, J. F., Protein Translocation Across Membranes, Biochemica et Biophisica ACTA Biomembranes, v. 1513, n. 1, p. $1-24$, 2001.

[22] GARCIA, R. A.; PANTAZATOS, S. P.; PANTAZATOS, D. P., et al, Cholesterol Stabilizes Hemifused Phospholipid Bilayer Vesicles, Biochimica et Biophysica ACTA Biomembranes, v. 1511, n. 2, p. $264-270,2001$. 
[23] DIMOVA, R.; ARANDA, S.; BEZLYEPKINA, N., et al, A Practical Guide to Giant vesicles. Probing the Membranes Nanoregimes via Optical Microscopy, Journal of Physics: Condensed Matters, v. 18, n. 28, p. 1151 - 1176, 2006.

[24] HADJICHARALAMBOUS, C., SHEYNIS, T., JELINEK, R. et al, Mechanisms of \#-Defensin Bactericidal Action: Comparative Membrane Disruption by Cryptdin-4 and Its Disulfide-Null Analogue, Biochemistry, v. 47, n. 47, p. 12626 - 12634, 2008.

[25] ANDRUSHCHENKO, V. V., AARABI, M. H., NGUYEN, L. T. et al, Thermodynamics of the interactions of tryptophan-rich cathelicidin antimicrobial peptides with model and natural membranes, Biochimica et Biophysica Acta - Biomembranes, v. 1778, n. 4, p. $1004-1014,2008$.

[26] AVANTI POLAR LIPIDS - The Phospholipid and Sphingolipid People. Disponível em: < http://www.avantilipids.com>. Acessado em: 18/11/2008.

[27] PATTY, P. J. AND FRISKEN, B. J., The Pressure-Dependence of the Size of Extruded Vesicles, Biophysical Journal, v. 85, n. 2, p. 996 - 1004, 2003.

[28] MOLECULAR PROBES - Product Structure C1904. Disponível em http://products.invitrogen.com/ivgn/en/US/adirect/invitrogen? $\mathrm{cmd}=$ catProductDetail\&entr yPoint=adirect\&productID=C1157\&CID=AFLBC\&messageType=catProductDetail.

Acessado em 18/02/2009.

[29] VERLY, R. M.; RODRIGUES, M. A.; DAGHASTANLI, K. R. P., et al, Effect of cholesterol on the interaction of the amphibian antimicrobial peptide DD $\mathrm{K}$ with liposomes, Peptides, v. 29, n. 1, p. 15-24, 2008.

[30] ANGELOVA, M. AND DIMITROV, D., Liposome Electroformation, Faraday Discussion of Chemical Society, v 81, n. 81, 303 - 311, 1986.

[31] KIN, K. AND SALEH, O. A., Stabilizing Method for Reflection Interference Contrast Microscopy, Applied Optics, v. 47, n. 12, p. 2070 - 2075, 2008.[

[32] KELLY, S. M., JESS, T. J. AND PRICE, N. C., How to Study Proteins by Circular Dichroism, Biochimica et Biophysica Acta, v. 1751, n. 2, p. 119 - 139, 2005.

[33] ISTITUTO NAZIONALE PER LA FISICA DELLA MATERIA C/O DIPARTIMENTO DI FISICA - Biophysics. Disponível em $<$ http://www.mi.infm.it/ biolab/>. Acessado em 29/11/2008.

[34] VAN HOLDE, K. E., JOHNSON, W. C. AND HO, P. S. et al. Principles of Physical Biochemistry (Second Edition), Pearson Prentice Hall, 2006.

[35] CDPRO - A Software Package for Analyzing Protein CD Spectra. Disponível em $<$ http://lamar.colostate.udu/ sreeram/cdpro/main.html >. Acessado em 14/08/2006. 
[36] SREERAMA, N. AND WOODY, R. W., Estimation of Protein Secondary Structure from Circular Dichroism Spectra. Comparison of Contin, Selcon and CDSSTR Methods with an Expanded Reference Set. Analytical Biochemistry, v. 287, n. 2, p. 252 $260,2000$.

[37] CAMPBELL, L. D. AND DWEK, R. A., Biological Spectroscopy, The Benjamin/Cummings Publishing Company, Inc., 1984.

[38] LAKOWICZ, J. R. Principles of Fluorescence Spectroscopy (Second Edition), Springer, 1999.

[39] OLYMPUS - Microscopy Resource Center. Jablonski Energy Diagram. Disponível em $\quad<$ http://www.olympusmicro.com/primer/java/jablonski/jabintro $>$. Acessado em 18/11/2008.

[40] YANG, J. Y.; SHIN, S. Y.; LIM, S. S., et al, Structure and Bacterial Cell Selectivity of a fish-derived antimicrobial peptide, Pleurocidin, Journal of Microbiology and Biotechnology, v. 16, n. 6, p. 880 - 888, 2006.

[41] CHEN, R. F AND KNUTSON, J.R, Mechanism of Fluorescence Concentration Quenching of Carboxyfluorescein in Liposomes: Energy Transfer to Nonfluorescennt Dimers, Analytical Biochemistry, v. 172, n. 1, p. 61 - 77, 1988.

[42] ROUSER, G., FLEISCHE, S. AND YAMAMOTO, A., 2 Dimensional Thin Layer Chromatographic Separation of Polar Lipids and Determination of Phospholipids by Phosphorus Analysis of Spots, Lipids, v. 5, n. 5, p. 494 - 496, 1970.

[43] CASAllanOVO, F., Oliveira, F. J. F., SOUZA, F. C. et al, Model Peptides Mimic the Structure and Function of the N-terminus of the Pore-Forming Toxin Sticholysin II, Biopolymers, v. 84, n. 2, p. 169 - 180, 2006.

[44] WOODY, R. W., In the Peptides (volume 7), Academic Press, 1985.

[45] DORRANCE, A. M., GRAHAM, D., DOMINICZAK, A., et al, Inhibition of Nitric Oxide Synthesis Increases Erythrocyte Membrane Fluidity and Unsaturated Fatty Acid Content, American Journal of Hypertension, v. 13, n. 11, p. 1194 - 1202, 2000.

[46] AHYAYAUCH, H.; LARIJANI, B.; ALONSO, A., et al, Detergent Solubilization of Phosphatidylcholine Bilayers in the Fluid State Influence of the Acyl Chain Structure, Biochimica et Biophysica Acta, v. 1758, n. 2,p. 190 - 196, 2006.

[47] STANEVA, G.; SEIGNEURET, M.; KOUMANOV, K., et al, Detergents Induce Raft-like Domains Budding and Fission from Giant Unilamellar Heterogeneous Vesicles. A Direct Microscopy Observation. Chemistry and Physics of Lipids, v. 136, n. 1, p. 55 66, 2005. 
[48] TAN, A.M.; ZIEGLER, A.; STEINBAUER, B., et al, Thermodynamics of Sodium Dodecyl Sulfate Partitioning into Lipid Membranes. Biophysical Journal, v. 83, n. 3, p. $1547-1556,2002$.

[49] KRAGH-HANSEN, U.; LE MAIRE, M.; AND MOLLER, J. V., The Mechanism of Detergent Solubilization of Liposomes and Protein-Containing Membranes, Biophysical Journal, v.75, n. 6, p. 2932 - 2946, 1998.

[50] DÖBEREINER, H-G., Properties of Giant Vesicles, Current Opinion in Colloids \& Interface Science, v. 5, n. 3-4, p. 256 - 263, 2000.

[51] AMBROGGIO, E.E., SEPAROVIC, F., BOIE, J.H. et al, Direct Visualization of Membrane Leakage Induced by the Antibiotic, Biophysical Journal, v. 89, n. 3, p. 1874 $1881,2005$.

[52] LEE, M.T., HUNG,W.C., CHEN, F.Y., HUANG, H.W., Mechanism and kinietics of pore formation in membranes by water-soluble amphipathic peptides, Procedings National Academic Science, v. 105, n. 13, p. 5087 - 5092, 2008.

[53] MALLY, M., MJAHENC, J., SVETINA, et al., The response of giant phospholipid vesicles to pore-forming peptide melitin, Biochimica et Biophysica Acta, v. 1768, n. , p. 1179-1189, 2007.

[54] TAMBA, Y., OHBA, S., KUBOTA, M. et al. Single GUV Method Reveals Interaction of Tea Catechin (-)-Epigallocatechin Galltate with Lipid Membranes, Biophysical Journal, v. 92, p. 3178 - 3194, 2007. 